\title{
A review and revision of the Jurassic-Early Cretaceous Globigerinina, with especial reference to the Aptian assemblages of Speeton (North Yorkshire, England)
}

\author{
F. T. BANNER and DAMINI DESAI \\ Department of Geological Sciences, University College London, \\ Gower Street, London WC1E 6BT
}

\begin{abstract}
The classification of the Jurassic to Albian Globigerinina is revised, phyletically and taxonomically. The Favusellacea comprise the genera Globuligerina (Jurassic) and Conoglobigerina (Jurassic-earliest Cretaceous), its descendant Favusella (Hauterivian to Cenomanian) and Ascoliella nov. (type species $A$. scotiensis nov.) (Aptian-Albian). The Globigerinacea include the families Praehedbergellidae nov. (from which the Hedbergellidae and its allies are descended) and the Schackoinidae; both are microperforate and nonmuricate. The Praehedbergellidae originate with Gorbachikella nov. (type species $G$. kugleri (Bolli)) and include Praehedbergella (Hauterivian-Aptian, including $P$. tatianae nov., $P$. grigelisae nov.), Wondersella, Blefuscuiana nov. (including $B$. kuznetsovae nov., $B$. mitra nov., B. multicamerata nov., $B$. speetonensis nov., $B$. globigerinelloides (Subbotina) lobulata nov. and $B$. occulta (Longoria) quinquecamerata nov.) (Barremian to Danian) and Lilliputianella nov. (including L. longorii nov.) (Aptian). The Schackoinidae includes Blowiella, Leupoldina and Schackoina. All the genera have their diagnoses emended as they are reinterpreted in accordance with the revised phyletic classification. Suggestions are made to explain the adaptive evolution of the taxa to the developing Early Cretaceous ocean.
\end{abstract}

\section{INTRODUCTION}

The Globigerinina have been developed as one of the most useful biostratigraphic tools for correlation of Cretaceous strata; the late Albian and younger taxa have been carefully reviewed within the last decade by the European Working Group on Planktonic Foraminifera as part of project number 58 ("mid-Cretaceous events") of the International Geological Correlation Programme. From this work an Atlas of species was published (Robaszynski and Caron, 1979) and a refined taxonomy and stratigraphy, based on the phylogeny of Late Cretaceous taxa, was developed (Robaszynski et al., 1984).

However, the phylogeny of Early Cretaceous globigerine taxa largely remains an enigma. Many attempts had been made to use pre-Albian species as zonal indices (Signal, 1965, 1977; Bolli, 1966; Bandy, 1967; Longoria, 1974; Grigelis and Gorbachik, 1980; Gorbachik and Kuznetsova, 1983; etc.) but few were based upon phylogeny or a phyletically derived taxonomy. Caron (1985, p. 20-21) summarised what was known in a very simple scheme: Conoglobigerina of the Middle and Late Jurassic was thought to give rise to Globuligerina with a Late Jurassic to Aptian range, with this genus giving rise to Favusella in the Barremian and to Hedbergella in the "Early Cretaceous" (preBarremian). Hedbergella, ranging from Barremian to Maastrichtian, is then seen to be the ancestor of all the Globotruncanidae. This scheme differs but little from the more detailed phylogeny proposed by Bandy (1967). Much more detailed phylogenetic hypotheses have been proposed by Gorbachik (1986), who has suggested a zonal scheme for the Late Bajocian to Albian interval based upon the evolution of species of the Favusellidae (Gorbachik, op. cit. p. 60-78) and, separately, a stratigraphy of the Hauterivian to Cenomanian based upon a phylogeny of the Schackoinidae, Ticinellidae and Rotaliporidae, in her understanding of those families (Gorbachik, cit., p. 89-93, $112-117)$. In this paper we have attempted to emend the morphological limits of genera, to examine the sequence of species which they would contain, to deduce their stratigraphic ranges and phylogenetic affinities, and to evolve a supraspecific taxonomy which can be applied morphologically, reflects phylogeny and refines biostratigraphy. Of necessity we have depended on the SEM imagery of many Jurassic taxa which have been published by Gorbachik and her colleagues, but we have endeavoured to devise a systematic approach which satisfies all reliable published data known to us as well as the material which we have directly studied. We believe the result (summarised in Figure 1) to be the first comprehensive systematisation and phyletic classification of the pre-Albian Globigerinina, as a base for pre-Albian planktonic foraminiferal biostratigraphy and evolutionary dynamics.

The most cursory examination of Early and Late 
Cretaceous planktonic foraminifera assemblages shows that, with a few exceptions, pre-Albian species are small and smooth-walled, while post-Aptian species are usually larger, have muricate surfaces and can develop keels. Part of this difference was recognised by Gorbachik and Moullade (1973) in their distinction between a redefined Schackoinidae, Planomalinidae and Globotruncanidae. It is possible to recognise a Barremian-Aptian assemblage, as distinguished from an Albian-Cenomanian one, even if no species names are applied. Although there is sometimes gross similarity in coiling mode and test shape between Early and Late Cretaceous species, distinctions between the two are easily recognisable. Our systematics attempt to define and clarify these differences, point out their phyletic and taxonomic significance and to seek their origins.

\section{MATERIALS}

In this paper we have concentrated our substantive taxonomic description upon the Late Aptian assemblages of Speeton, North Yorkshire, because they have never before been described and because they exemplify most of the morphological characters we need to illustrate, to substantiate our reclassification of the Early Cretaceous species. The Speeton Clay is the most complete outcrop section of marine Early Cretaceous strata in Britain. It has been the subject of extensive study by stratigraphers, and although it contains nonsequences, it remains the standard reference section. The locality is described by Kaye (1964) and the cephalopod stratigraphy has been revised by Rawson $e t$ al. (1978). The "A beds" are known to span Middle Aptian to Earliest Albian times, but are badly slumped. Our samples cannot be precisely placed within these Neohibolites ewaldi-bearing sediments, but they have been independently analysed for nannofloras by J. A. Crux, whom we thank for this biostratigraphic assessment:-

Sample 8109, an abundant and diverse nannoflora, including Nannoconus quadriangulus apertus Deflandre and Deflandre, known from the "Schackoina" cabri zone of the lower part of the Gargasian stratotype and reported to be restricted to the Late Aptian; Rhagodiscus angustus (Stradner, 1963) Reinhardt and Lithostrinus floralis Stradner, of "Middle Aptian" and younger range, and the former occurring in the Upper Bedoulian and lower Gargasian stratotypes; Eprolithus varolii Jakubowski, recorded from North Sea oil wells and North Germany (Otto Gott pit, Sarstedt, near Hannover, Late Aptian).

Sample 8106; $R$. angustus, $L$. floralis, $N$. quadriangulus apertus, $E$. varolii, etc., essentially the same as sample 8109.

Sample 8109; essentially the same as 8106 (but lacking E. varolii).

Sample 8108; E. variolii, $R$. cf. angustus, etc.

Sample 8103; Rhagodiscus asper (Stradner)

Reinhardt, Assipetra infracretacea (Thierstein) Roth.

The nannofloras indicate a late Early to Late Aptain age for samples $8106,8107,8108$ and 8109 , the sparse assemblage of 8103 being datable only to the Ryazanian-Albian interval. This is in full accord with the independent evidence of the planktonic foraminifera which can refer them all to the Leupoldina cabri zone (of Longoria, 1974, considered by him to be of early Late Aptian age) (the "Middle Aptian" of Gorbachik, 1986).

The ostracod asemblage of sample 8109 has been studied for us by A. R. Lord, who has reported Cytherella cf. ovata (Roemer), C. cf. parallela (Reuss), Paracypris cf. jonesi Bonnema, Rehacythereis buechlerae (Oertli), Hechticythere derooi (Oertli) and Parataxodonta uralensis Mandelstam sensu Oertli, an assemblage most similar to that of the stratotype Gargasian but containing far fewer species.

Other material examined for this study has included Barremian and Aptian assemblages from the Kopervik Formation of the Central North Sea (which will be described in a later paper); Oxfordian, Tojeira Shale from Montejunto, Portugal (sections Tojeira 1 and 2 of Stam 1986); the Seibold and Seibold Jurassic collection and the Riegraf Jurassic collection at Tübingen; the Risch Barremian-Albian collection at Tübingen; and D.S.D.P. material (sites 398,549 at University College London and samples from Legs 1, 11, 13, 17, 25, 27, 36, $41,44,50$, and 79 at Tübingen). Samples from the Washita group of Texas and the Albian of England (Barnard collection) have been available at University College London. 160 samples from Hauterivian to Late Aptian of Sarstedt (Otto Gott pit), the Early to Late Hauterivian of Moorberg, and the Late Aptian of Vohrum and other localities in N. W. Germany (Lower Saxony Basin, from sections described by Mutterlose, 1984) have also been analysed. Finally, one of us (F.T.B.) has been able to study the Barremian-Albian sequence of the Thamama-Nahr Umr of the United Arab Emirates (see Banner and Strank, 1987).

The specimens (including those Figured here) were mounted for SEM study on stubs with double-sided sellotape as fixative. No glues or solvents were employed during preparation or mounting.

\section{SYSTEMATIC DESCRIPTIONS Superfamily Favusellacea Michael 1972 emend., nom transl.}

Diagnosis. Test trochospiral, composed of two or more whorls of subglobular or reniform chambers; initially with four or more chambers per whorl, final whorl of about four chambers, rarely as many as seven: spiral 
side completely evolute, umbilical side almost completely involute, with a small umbilicus; aperture typically intraumbilical, rarely becoming intraextraumbilical, a low or high and narrow arch, which may be strongly asymmetric; wall microperforate (external diameters $<1.5 \mu \mathrm{m})$, covered with muricae which may be separated or which may fuse laterally into short ridges: the ridges may anastomose to form partial or complete reticulations over the test surface. The wall is believed to be composed of aragonite.

\section{Key to the genera of the Favusellacea.}

1. Wall with muricae, no continuous reticulation, aperture intraumbilical; four chambers in the final whorl: Family Globuligerinidae Loeblich and Tappan, 1984.

1.1. Aperture a high, asymmetric arch, with a distinct lip (porticus?), test low or moderately high spired: Genus Globuligerina Bignot and Guyader, 1971 (type species, $G$. oxfordiana Grigelis, 1958): ?Bajocian-Bathonian-Oxfordian.

1.2. Aperture a low, symmetrical arch, with or without a distinct lip, test high or low spired: Genus Conoglobigerina Morozova, 1961 (type species. $C$. dagestanica Morizova, 1961): Bajocian-Valanginian.

2. Wall with continuous reticulation of anastomosing ridges, four to seven chambers in the final whorl: Family Favusellidae Michael, 1973.

2.1. Aperture intraumbilical; four to five chambers in the last whorl: Genus Favusella Michael, 1973 (type species, Globigerina washitensis Carsey, 1926) (typonym: Reticuloglobigerina Reiss, 1963, nomen oblitum): Hauterivian-E. Cenomanian.

2.2. Aperture intra-extraumbilical; five to seven chambers in the final whorl: Genus Ascoliella n. gen. (type species, Ascoliella scotiensis n. sp): AptianAlbian.

Remarks. There appears to be a clear stratigraphical, morphological and phylogenetic unity within this superfamily. All (with the exception of some of the post-Barremian Favusellidae) are small, terminally quadriserial, globigerine-like forms with a conspicuous surface structure of muricae or ridges or both. The only known microperforate and muricate genus of the Globigerinina, which at all resembles any member of the Favusellacea, is Globastica Blow (type species, Globigerina daubjergensis Brönnimann) of the Danian, which can be phyletically only remotely related. Both Globuligerina and Conoglobigerina are muricate and characterise the Jurassic, and the youngest Conoglobigerina (of the Berriasian-Valanginian) show clear gradation into the Favusellidae of the Cretaceous, where favose reticulation develops continuously on the test surface.
The unity of the Favusellacea is emphasised by the recognition (Gorbachik and Kuznetsova, 1986) that Globuligerina oxfordiana (Lower Oxfordian). Conoglobigerina meganomica (Callovian) and Favusella washitensis (Late Albian) all possess walls which were primarily aragonite. This mineralogy is unique within the Globigerinina and alone would require the separation of these genera into a distinct superfamily.

Conoglobigerina and Globuligerina have previously been distinguished principally on the greater height of the spiral side of the former (e.g. Grigelis and Gorbachik, 1980). The height of the spire is variable; Stam (1986), who measured the height/diameter ratio of many hundreds of specimens from many localities (the Grand Banks and Portugal), concluded that it could not be used for generic distinction. However $G$. oxfordiana (the type species of Globuligerina), $G$. bathoniana (Pazdrowa) and G. calloviense Kuznetsova all possess a high, "bulimine" aperture, whereas Conoglobigerina dagestanica Morozova and its allied species, like Favusella washitensis and its relatives, possess a low, arched, virtually symmetrical, primarily intraumbilical aperture. The "bulimine" aperture of Globuligerina is unique within the Globigerinina and surely indicates a generic identity to those species which possess it. On this criterion, the genus Globuligerina appears to have a stratigraphical range from Bathonian ( $G$. bathoniana), through Callovian $(G$. calloviense) to Oxfordian (G. oxfordiana) with doubtful records in the Late Bajocian and Early Kimmeridgian (Stam, 1986: Riegraf, 1987a), and left no descendants. In contrast, Conoglobigerina is of much greater stratigraphic range; the oldest known species $(C$. balakhmatovae (Morozova), C. avarica (Morozova), $C$. gaurdakensis (Balakhmatov and Morozova)), are all recorded from the Bajocian (Riegraf, 1987), and the youngest (C. stellapolaris (Grigelis), Kimmeridgian to Tithonian; $C$. conica (lovčeva and Trifonova), Tithonian; C. gulekhensis (Gorbachik and Poroshina), Berriasian-Valanginian) show a morphological and phyletic gradation into favusellid Cretaceous descendants.

Although the $40 \mathrm{my}$ range of the Globuligerinidae was almost as lengthy as that of the Hedbergellidae, and although both families are characterised by the possession of muricae, the Globuligerinidae remained unspecialised, never gaining intra-extraumbilical apertures, radially elongate chambers or peripheral muricocarinae. Even the Favusellidae, their direct descendants, remained architecturally unmodified except for the development of an intra-extraumbilical aperture in Ascoliella gen. nov., near the end of their phylogenetic span. This contrasts greatly with the evolution both of the Hedbergellidae and the Praehedbergellidae, where coiling-mode and other architectural characteristics were the subject of repeated and rapid evolution through their stratigraphical duration. 
Independently, Grigelis and Gorbachik (1980) have recognised the strong affinity between Globuligerina, Conoglobigerina and Favusella by placing them all in the Favusellidae, and Gorbachik (1986, p. 76-77) observed that muricae, fusing laterally, produce ridges which evolved into Favusellid reticulation. However, our independent treatment defines the genera and traces the Jurassic evolution quite differently.

The origins of the Favusellacae remain obscure, although Fuch's postulate (1975), that they arose from Oberhauserellidae in Early to Middle Jurassic time, remains unrefuted. The appearance of a meroplanktic life cycle would explain the "discorbid" appearance of early (benthic?) ontogenic whorls coupled the "globigerine" (planktic?) later chambers in, e.g. Conoglobigerina dagestanica (Banner, 1982). However, Fuch's material needs re-examination with SEM before it can properly be evaluated: this applies also to the new taxa described by him as Tectoglobigerina calloviana gen. nov., sp. nov., Woletzina irregularis gen. nov., sp. nov., Globuligerina umbilicata sp. nov., G. frequens sp. nov., etc. from the Late Callovian and Early Oxfordian of Poland (Fuchs, 1973). It is not possible to assess these taxa in this contribution. It is noteworthy that Fuchs (1973, 1975) separated Conoglobigerina (into Globigerinacea) from Globuligerina (into the Robertinacea) primarily on apertural characteristics, a conclusion quite independent of, but not dissimilar to our own.

Family Globuligerinidae Loeblich and Tappan Genus Globuligerina Bignot and Guyader, 1971 emended.

Pl. 1, figs. 1-4.

Diagnosis. Test trochospiral, of two or more whorls; initially with four or more (commonly five) chambers per whorl, final whorl consisting of four chambers; spiral side completely evolute, a low or high spire; umbilical side almost completely involute, with a narrow but distinct umbilicus; aperture a narrow, high, asymmetrical, loop-shaped, "bulimine-like" opening, perpendicular or oblique to the basal suture, with which it is in contact at, or anterolaterally to, the umbilical centre. Wall microperforate (external diameter $<1.5 \mu \mathrm{m}$ ), muricate, the muricae sometimes sporadically aligning and fusing to form short, sinuous, discontinuous ridges. Wall believed to be primarily aragonite.

Remarks. Riegraf (1987a and 1987b) has compiled a list of all published records of supposed Globigerinina of Jurassic age; reference may be made to it. The emendation above restricts the genus Globuligerina, so that the only well described species certainly referable to it are $G$. bathoniana (Globigerina bathoniana Pazdrowa, 1969, topotypes refigured by Masters (1977, pl. 22, figs. 1-3) and by Stam (1986, pl. 9, figs. 6-13),
Middle Bathonian), G. calloviense Kuznetsova (in Kuznetsova and Uspenskaya, 1980, topotype refigured by Gorbachik, 1986, pl. 6, figs. 1-2, Early Callovian) and $G$. oxfordiana Grigelis (1956, from the Early Oxfordian, Cardioceras cordatum/Quenstedtoceras mariae zone according to Grigelis, 1985, pp. 93, 108, 66-70).

Good specimens of $G$. oxfordiana, the type species, showing the wall and apertural structures clearly, have been figured by Gorbachik (1986, pl. 6-9), Bignot and Guyader (1971, pl. 1, figs. 1-3, pl. 2, fig. 3) and by Wernli and Kindler (1986, pl. 1, figs. 1-4). The loop-shaped aperture is surrounded by a distinct, projecting rim which is reflexed in its posterior interiomarginal part so deeply as to suggest the presence there of an internally projecting structure. Externally, the aperture is reminiscent of that of the Buliminacea and is unlike any other seen in the Globigerinina. The aperture of Conoglobigerina, described below, is very different and the relationship between the two genera remains obscure. Both are grouped here within the Globuligerinidae because of their similarities of wall surface, planktonic habitat and not dissimilar stratigraphic age.

Genus Conoglobigerina Morozova (in Morozova and Moskalenko), 1961, emended. PI. 1, figs. 5a-b.

Diagnosis. Test trochospiral, of two or more whorls; initially with four or more (commonly five or six) chambers per whorl, final whorl consisting of four chambers; spiral side completely evolute, a low or high spire; unbilical side almost completely involute, with a narrow but distinct umbilicus; aperture an interiomarginal, almost symmetrical intraumbilical arch, with or without a narrow rim-like lip. Wall microperforate (external diameter $<1.5 \mu \mathrm{m}$ ), muricate, the muricae sometimes sporadically aligning and fusing to form sinuous ridges, which may locally anastomose but which never form a continuously developed reticulum over the test surface. Wall believed to be primarily aragonite.

Remarks. Conoglobigerina as emended is distinguished from Globuligerina by its intraumbilical low arched aperture (not high, loop-shaped, asymmetric and "bulimine"). Conoglobigerina is distinguished from Favusella by the presence in the latter of a continuously developed reticulum of ridges over the whole test surface.

Even if the wall surface is diagenetically altered beyond recognition of the original structure, Conoglobigerina can still be distinguished from Globuligerina by its apertural characteristics. An example may be taken from the topotype specimens of $C$. helvetojurassi$c a$ (Haeusler) illustrated in SEM by Masters (1977, pl. 21, figs. 2-4, M. Oxfordian). 
Stam (1986, p. 106) has shown that the height/ diaineter ratio for $C$. dagestanica (the type species of Conoglobigerina) has virtually the same range of values as that possessed by Globuligerina bathoniana and that, therefore, the relative height of the spire is not a valid distinction between the two genera (Stam, 1986, considered them to be synonyms).

The type species of Conoglobigerina, by original designation, is "Globigerina (Conoglobigerina)" dagestanica Morozova (in Morozova and Moskalenko, 1961), from the Early Bathonian of Dagestan. The original drawings were barely adequate for its identification, and Loeblich and Tappan (1964, p.C 652) erroneously assumed that Conoglobigerina should be regarded as a junior synonym of Gubkinella (a middle to late Cretaceous, probable Heterohelicid). However, SEM imagery of topotypes (Gorbachik and Grigelis, 1980, pl. 1, figs. 1-2; Gorbachik, 1986, pl. 1, figs. 1-3) has shown the muricate, microperforate wall and low, arched intraumbilical aperture which must be taken to be typical of Conoglobigerina. The height/diameter ratio of topotypes appears to be about unity. In the illustrated specimens, the initial spiral chambers are obscure but there may be five in the early whorls; the last whorl consists of 3 to 4 chambers.

The Early Bathonian of Dagestan is also the type horizon for Conoglobigerina balakhmatovae (Globigerina (Eoglobigerina) balakhmatovae Morozova, in Morozova and Moskalenko, 1961, p. 621, photographed on pl. 1, figs. 1-12, and with 21 line drawings as text fig. 5). The low, intraumbilical aperture (op. cit. pl. 1, figs. 3, 7, 11) and the strong muricae (op. cit. pl. 1, fig. 5) are well shown. Morozova (1961) believed $C$. balakhmatovae to be dimorphic, the microspheric generation (op. cit., pl. 1, figs. 1,4) having five or six chambers in the first whorl, but the megalospherics possessing only three to four chambers per whorl initially. The specimens imaged in SEM by Gorbachik (1986, pl. 4, figs. 1-3, Bajocian, Caucasus) show distinct muricae on the spiral side where five chambers per whorl are visible initially. Morozova (1961) obtained similar specimens from the Late Bajocian (Turkmenian SSR); therefore dimorphism, if it occurs, appears to be present in both Late Bajocian and Early Bathonian populations of $C$. balakhmatovae; all figured specimens have four chambers in the last whorl and a true, although small umbilicus. The dimorphism, the "discorbid" appearance of the early whorls of the supposed microspheric generation, and the apparently restricted biogeographic range of this species, all suggest that it was meroplanktonic (at least in the B-generation). Therefore, it is probable that this species is phyletically close to the benthonic ancestor of the Favusellacea.

Although C. balakhmatovae is low spired (height/ diameter ratio about 0.5 ) this does not preclude it from the genus Conoglobigerina (as noted above). In contrast, some very high spired species seem to have been wrongly placed in Conoglobigerina. For example, "Globigerina (Conoglobigerina)" avarica Morozova (1961), from the Early Bathonian of Dagestan, is very high spired (height/diameter ratio about 1.6) but its tiny aperture and a lack of an umbilicus exclude it from Conoglobigerina and even from the Globigerinina; it is similar to Gubkinella but its aperture does not extend to the periphery.

"Globigerina (Conoglobigerina)" gaurdakensis Balakhmatova and Morozova (in Morozova and Moskalenko, 1961, Late Bajocian. Turkmenia) "Globigerina" spuriensis Bars and Ohm (1968. Late Bajocian or Earliest Bathonian, Northern Italy) and "Globigerina" jurassica Gofman (1958. Bathonian or Early Callovian. Crimea) are all inadequately illustrated in the literature and must be restudied before their generic identity can be sure.

Conoglobigerina stellapolaris (Globuligerina stellapolaris Grigelis, in Grigelis et al., 1977), from the Volgian of the USSR. has a height/diameter ratio of 0.75 and about 4 chambers in the final whorl; its aperture is the low intraumbilical arch typical of Conoglobigerina (Grigelis et al. 1977, fig. 16) and the muricae of its wall are linked sporadically into irregular short sinuous ridges over the whole test surface (Gorbachik. 1986. pl. 10 and Plate 1, fig. 5a-b). This species, which is known from the Early Kimmeridgian to Late Tithonian (Grigelis and Gorbachik, 1980; Gorbachik and Kuznetsova, 1983) heralds the latter advent of Favusella by the relatively complete lateral fusion of its muricae but no true reticulation has yet developed.

High-spired species of Conoglobigerina persist at least as high as Tithonian. $C$. conica (Iovčeva and Trifonova, 1961) has a height/diameter ratio of about 1.2 ; its initial whorl is depicted as possessing about 6 chambers (rapidly reducing to a final whorl of four). It is not impossible that $C$. conica is the microspheric counterpart of $C$. terquemi (Globigerina terquemi Iovčeva and Trifonova, 1961) which occurs in the same Tithonian Limestones, has a height/diameter ratio of 0.6 , and has $4 \frac{1}{2}-4$ chambers in the whorl throughout. Therefore dimorphism may be suggested to occur both in the oldest ( $C$. balak/matolae) and the youngest species of Conoglobigerina in the Jurassic record. although no suggestion of dimorphism can yet be made for any other genus of Mesozoic Globigerinina.

Both the holotype and the paratype of $C$. terquemi figured by lovčeva and Trifonova (1961, pl. 2, figs. 10. 13) possess a bulla-like structure on the umbilicus. Such a structure is common in Fav'usella w'ashitensis (e.g. the neotype proposed by Longoria, 1974) and $F$. stiftia (Rössler et al., 1979. pls. 1. 2), and its appearance in $C$. terquemi also possibly heralds the future evolution of Fav'usella from Conoglobigerina. 
The stratigraphically youngest, typical Conoglobigerina is $C$. caucasica (Globuligerina caucasica Gorbachik and Poroshina, 1979), which has its type horizon in the Early Berriasian of the Crimea but which ranges up to the Late Valanginian (Grigelis and Gorbachik, 1980; Gorbachik and Kuznetsova, 1983). C. caucasica is low spired (height/diameter ratio 0.5), with five chambers per whorl reducing to four, a simple intraumbilical aperture and crowded muricae over its surface (Gorbachik and Poroshina, 1979, text figs. 3b, 3d). C. gulekhensis (Globuligerina gulekhensis Gorbachik and Poroshina, 1979) has the same recorded stratigraphic range and distribution as $C$. conica but has a higher spire (height/diameter ratio 0.8 ) and the muricae of its surface form ridges which fuse to form incomplete reticulations (Gorbachik and Poroshina, 1979, pl. 1, figs. $1 \mathrm{~b}-1 \mathrm{~d}$, and Plate 2, figure 5). The BerriasianValanginian occurrence of $C$. gulekhensis (Late Valanginian according to Gorbachik and Kuznetsova, 1984 , p. 129) perfectly predates the appearance of continuous reticulation on the surface of the Hauterivian Favusella hoterivica, which we believe to be its direct and immediate descendant.

Family Favusellidae Michael, 1973 Genus Favusella Michael 1973, emended Pl. 1, figs. 6-8; pl. 2, figs. 6-7.

Diagnosis. Test trochospiral, of two or more whorls, with four to five chambers in each whorl; spiral side completely evolute, umbilical side almost completely involute; aperture intraumbilical, a low or moderately high, symmetrical arch, usually with a narrow lip-like porticus; wall microperforate (external diameter $<1.2$ $\mu \mathrm{m})$, the surface covered by anastomosing ridges which enclose groups of microperforations in a favose reticulation; muricae may or may not be present at the confluences of the anastomosing ridges.

Remarks. The continuous reticulation of the surface ridges distinguishes Favusella from Conoglobigerina.

Earlier species of Favusella retain prominent muricae at the points of confluence of the ridges of the reticulum (Plate 1 , fig. $6 \mathrm{~b}$ and $7 \mathrm{~b}$ ) and the spaces between the ridges are narrow and concave (Plate 1 , fig. $8 \mathrm{a}, 8 \mathrm{~b})$. In $F$. washitensis the muricae at ridge confluences seem to be lost or are very weak, and the spaces between the ridges of the reticulum are flatfloored. This last characteristic ("ridges forming cells are sharply separated from the cell bottom") was used by Grigelis and Gorbachik (1980, p. 188) as a distinguishing character for the genus Favusella; we extend the concept of Favusella to include all species which possess a complete reticulum because this can be seen without very high-powered electron microscopy, and because all subsequent developments in surface sculpture are gradational and quantitative. The reticulum, once established, is not lost until the extinction of the lineage; therefore, the range of Favusella is now believed to be from the Early Hauterivian to Early Cenomanian. The earliest known true Favusella is $F$. hoterivica " Globigerina" hoterivica Subbotina, 1953, Hauterivian, N. Caucasus; also recorded as an index

\section{Explanation of Plate 1}

Favusellacea: Globuligerina, Conoglobigerina and the origin of Favusella.

Fig. 1a-c. Globuligerina oxfordiana (Grigelis), Tojiera 1 (Stam sample 6.15), Idoceras planula zone, Late Oxfordian, Portugal. 1a, $\times 350,1 \mathrm{~b}, \times 250,1 \mathrm{c}$, muricate wall detail, $\times 1,310$.

Fig. 2. Globuligerina oxfordiana (Grigelis), wall showing pustules (muricae) in partial alignment, interspersed with microperforations, $\times 1,700$, from Quenstedtoceras mariae zone, Normandy (after Bignot and Guyader, 1971).

Figs. 3a-b. Globuligerina oxfordiana (Grigelis), Early Oxfordian, Makarevo (after Gorbachik, 1986); 3a, whole specimen with typical "bulimine" aperture $\times 350,3 \mathrm{~b}$, detail of muricae, $\times 9,400$.

Fig. 4. Globuligerina bathoniana (Pazdrowa), $\times 770$, topotype from Ogrodzieniec, Poland, morrisi zone, Middle Bathonian (after Stam, 1986).

Figs. 5a-b. Conoglobigerina stellapolaris (Grigelis), from Early Volgian, Pechora, ASSR (after Gorbachik, 1986). $5 \mathrm{a}$, whole specimen, $\times 150,5 \mathrm{~b}$, anastomosing and flattening of muricae to form irregular ridges $\times 650$.

Figs. 6a-b. Favusella hoterivica (Subbotina), topotype, from Hauterivian, Pshish, Caucasus (after Gorbachik, 1986), 6a, whole specimen $\times 300,6 \mathrm{~b}$, detail of reticulate pattern of ridges, $\times 750$.

Figs. 7a-b. Favusella tardita (Antonova), Late Barremian, Tsitse, Caucasus (after Gorbachik, 1986), 7a, whole specimen, $\times 280,7 \mathrm{~b}$, reticulations with relict muricae, $\times 1,500$.

Figs. 8a-b. Favusella tardita quadricamerata (Antonova), Early Aptian, Mazytka, Caucasus (after Gorbachik, 1986). Detail of ridges forming a reticulum with microperforations; $8 \mathrm{a}, \times 2,350 ; 8 \mathrm{~b}, \times 8,450$. 


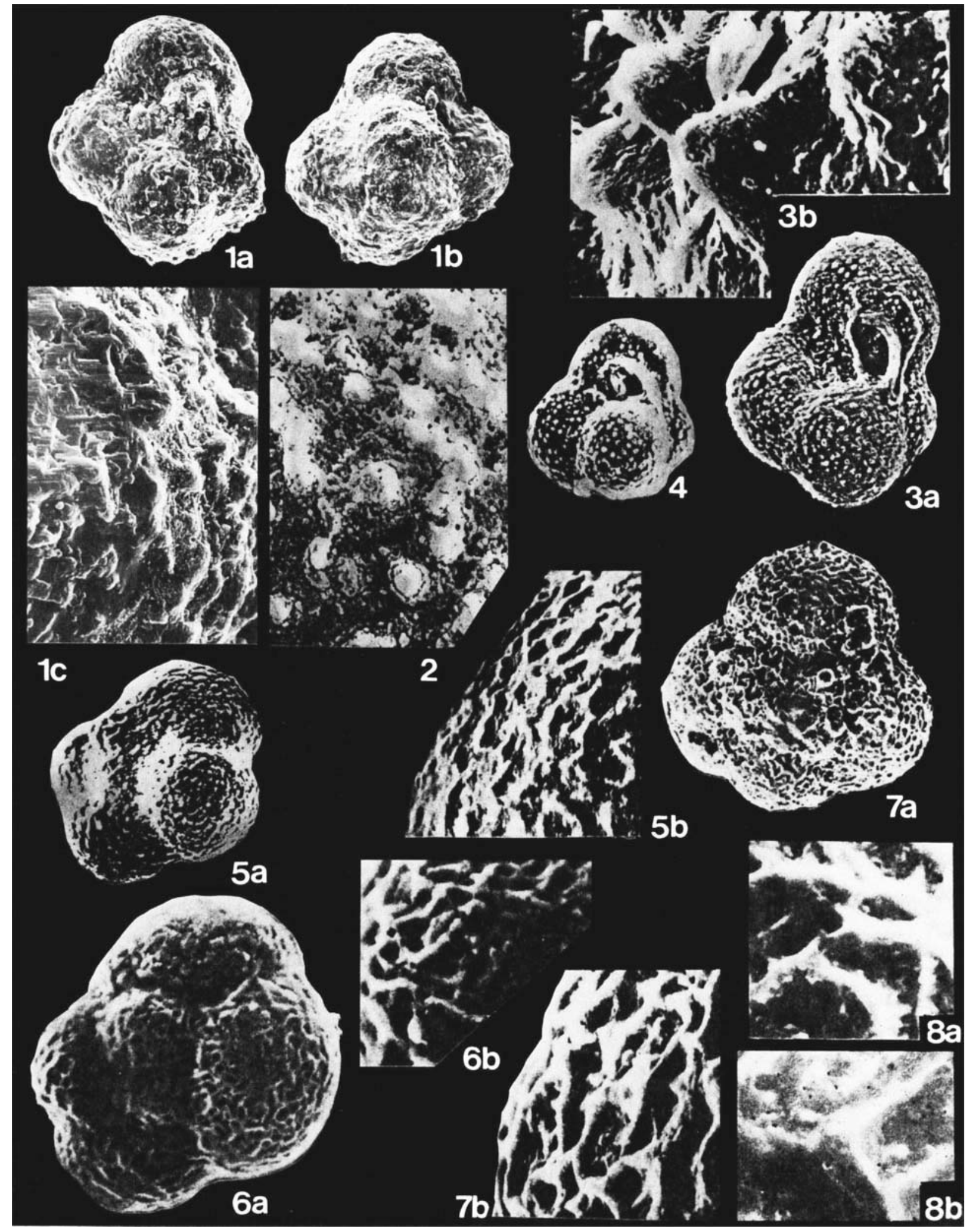


species for the Early Hauterivian of Azerbaidzhan by Ali-Zade and Khalilov, 1986). Topotypes in SEM (Gorbachik, 1986, pl. 11, figs. 1-2) possess a continuous reticulum but with very narrow inter-ridge spaces (containing only 2 or 3 microperforations) (Plate 1, figs. 6a-b). In Favusella stiftia (Rössler et al. 1979; see also Butt, 1979, pl. 3, as "Hedbergella hoterivica"), from the Barremian or Hauterivian of D.S.D.P. site 397 , the reticulum spaces are broader and contain clusters of about five to ten microperforations. The inter-ridge spaces are concave when relatively small, tending to be flat floored when broad (Rössler et al. 1979 , pl. 2, fig. 2c). The reticulation of $F$. tardita (Antonova) ("Globigerina" tardita Antonova, in Antonova et al. 1964) as depicted in SEM by Gorbachik (1986, pl. 13, figs. 1-3; Plate 1, figs. 7a-b), from the Late Barremian-Early Aptian of the N.W. Caucasus, seems to be very similar to that of $F$. stiftia, and the two species probably intergrade. In $F$. tardita quadricamerata (Antonova) ("Globigerina" quadricamerata Antonova in Antonova et al., 1964), from the Early Aptian, the inter-ridge spaces of the reticulum have broadened and the majority are flat-floored, containing at least ten microperforations (Plate 1, figs. 8a-b). $F$. washitensis (Globigerina washitensis Carsey, 1926) has the broadest inter-ridge spaces, and is flat-floored, with 15 to 20 or more microperforations in each space (Plate 2 , fig. 6a). The type specimens of $F$. washitensis, from the Washita group, Texas, are lost and neotypes have been proposed by Plummer (1931, from the "Del Rio Formation", Early Cenomanian) and by Longoria (1974, from the Grayson Formation of the same locality); the range of $F$. washitensis is known from Early Albian to "Middle" Cenomanian (Caron, 1985) and it may occur in horizons as old as Latest Aptian (Grigelis and Gorbachik, 1980). Therefore, the gradation from finely reticulate Hauterivian forms of Favusella to broadly reticulate forms in the AlbianEarly Cenomanian appears to be continuous and complete. Plate 2 , figs. $6 \mathrm{a}, \mathrm{b}$ shows how incipient muricae are preserved at the intersection of the ridges even in the youngest form of this lineage, recalling its conoglobigerine ancestor.

\section{Genus Ascoliella gen. nov.}

Type species. Ascoliella scotiensis n. sp.

Diagnosis. Test trochospiral, composed of two or more whorls of subglobular or reniform chambers, initially with about five chambers per whorl, final whorl of about six chambers; spiral side completely evolute, umbilical side almost completely involute, with a small, deep umbilicus; aperture a low interiomarginal arch, intraumbilical-extraumbilical in extent; wall microperforate, the surface covered by anastomosing ridges which enclose groups of microperforations in a favose reticulation.

Remarks. Ascoliella appears to evolve from Favusella in the Aptian by migration of the anterior end of the aperture beyond the umbilicus, and is therefore the only known example in the Favusellacea of a parallel to the evolution of Blefuscuiana from Gorbachikella in the Praehedbergellidae, Globigerinacea. Ascoliella persists to the Late Albian, because the species "Favusella" pessagnoi Michael (Fort Worth Formation), " $F$." quadrata Michael (Duck Creek Formation) and " $F$." nitida Michael (Duck Creek Formation) are all referable to it. Ascoliella appears to become extinct before the top of the Albian, whereas Favusella persists into the Early Cenomanian (Michael, 1973, p. 203).

Ascoliella scotiensis sp. nov. Pl. 2, figs. 3-4.

Favusella aff. washitensis (Carsey), Ascoli, 1976, p. 661,674 , pl. 1, figs. $4 a-c$.

Diagnosis. Ascoliella with 6 to 7 chambers in the last whorl, the chambers subglobular in axial view and reniform in spiral view: intercameral sutures weakly depressed and subradial.

Holotype. The specimen figured by Ascoli (1976, pl. 1, fig. 4a), Geological Survey of Canada No. 53770, from Oneida Well 0-25, side wall core at 7,605 feet, Aptian. Material. The remaining specimens figured by Ascoli (loc. cit, figs. 4b, c, GSC numbers 53771, 53772 respectively).

Remarks. This species was recognised by Ascoli (1976) to characterise an Aptian biozone in wells drilled on the Scotian shelf and south-west Grand Banks off Nova Scotia. It has not yet been recorded elsewhere and it may have been restricted to the western boundary current of the Early Cretaceous primitive Atlantic Ocean. Its stratigraphic position, together with the characters of its reticulation, suggests that it evolved directly from Favusella tardita, or $F$. tardita quadricamerata, and that it became extinct at or before the evolutionary appearance of Albian species of Ascoliella.

Ascoliella scotiensis, the earliest known species of Ascoliella, differs from $A$. nitida (Michael) in possessing a coarser reticulum with concave depressions rather than flat-floored inter-ridge spaces, and from $A$. pessagnoi (Michael) in having more depressed and reniform chambers with less depressed sutures. $A$. quadrata (Michael) has fewer, much more globular and rapidly enlarging chambers than in $A$. scotiensis. Derivation of Name: Ascoliella scotiensis bears a generic name proposed in honour of Pietro Ascoli, who first recognised its stratigraphical significance, and a specific 
name which indicates its provenance in the subsurface of the Scotian Shelf.

\section{Superfamily Globigerinacea Carpenter, Parker and Jones.}

Remarks. Following the work of Gorbachik and Kuznetsova (1986), this superfamily must be redefined to emphasise the calcitic nature of the wall as well as (following Blow, 1979) its possession of a true umbilicus.

Family Praehedbergellidae fam. nov.

Diagnosis. Globigerinacea with trochospiral tests, in which the primary aperture is intraumbilical or intraumbilical-extraumbilical and which possess a microperforate wall lacking muricae, crystallite pustules or spine bases; differs from the Favusellacea in its lack of muricae (and in possessing a calcitic test) and from the Schackoinidae in not becoming planospiral.

Key to the genera of the Praehedbergellidae

1. Aperture intraumbilical: genus Gorbachikella $\mathbf{n}$. gen. (type species: Globigerina kugleri Bolli, 1959), Callovian-Aptian.

2. Aperture umbilical-extraumbilical:

2.1. 4-41/2 chambers per whorl: genus Praehedbergella Gorbachik and Moullade, 1973 (type species: Globigerina tuschepsensis Antonova, 1964), Hauterivian-Aptian.

2.2. 5 or more chambers per whorl:

2.2.1. Chambers subglobular to reniform, depressed: genus Blefuscuiana $\mathrm{n}$. gen. (type species: $B$. kuznetsovae n. sp.,), Barremian-Early Danian.

2.2.2. Chambers subglobular to radially elongate: genus Lilliputianella $\mathrm{n}$. gen. (type species: $L$. longorii $\mathrm{n}$. sp.), Barremian-Aptian.

\section{Genus Gorbachikella gen. nov.}

Type species. Globıgerina kugleri Bolli, 1959.

Diagnosis. Test trochospiral, consisting of two or more whorls, initially with four or more chambers per whorl, and final whorl of four chambers, which are typically subglobular or reniform; spiral side completely evolute, umbilical side almost completely involute but with a distinct, true umbilicus; aperture intraumbilical, a low or high symmetrical arch; wall calcareous, microperforate (external diameters $<1.5 \mu \mathrm{m}$ ), smooth, not muricate, probably calcitic.

Remarks. Gorbachikella closely resembles Globigerina but its wall is smooth and microperforate. It differs from Tenuitellinata in lacking the crystallite pustules characteristic of the Tenuitellinae. Unlike Globuligeri$n a$, Gorbachikella has no muricae and it has a symmetrical simple aperture. Gorbachikella differs from Conoglobigerina in lacking muricae, and it differs from Favusella in its lack of a reticulum of anastomosing ridges. The true umbilicus of Gorbachikella places this genus in the Globigerinacea and distinguishes it from Gubkinella.

The phylogenetic origin of Gorbachikella is not known. It is unlikely that muricate Globuligerina, with its specialised aperture, could directly give rise to the smooth, unspecialised Gorbachikella. An origin even with Conoglobigerina (muricate but with a simple arched aperture) would also involve a loss of muricae and (from the work of Gorbachik and Kuznetsova, 1986) a change in the mineralogy of the wall from aragonite to calcite.

A Late Jurassic species referrable to Gorbachikella appears to be G. parva (Kuznetsova) (in Kuznetsova and Gorbachik, 1985, p. 113, pl. 16, figs. 1-2), from the Early Kimmeridgian of the Crimea. The wall appears to be typical, and the aperture is figured as low but intraumbilical.

"Globuligerina" meganomica Kuznetsova (in Kuznetsova and Uspenskaya, 1980 , p. 749, pl. 1, figs. 5-8) (re-illustrated by Kuznetsova and Gorbachik, 1985, p. 113 , pl. 16, figs. 7-8, and by Gorbachik, 1986, pl. 5, figs. 1-2), from the Early and Middle Callovian of the Crimea, is the stratigraphically oldest known species to be adequately illustrated and which is probably referable to Gorbachikella. None of the specimens so far imaged in SEM has a very well preserved wall, but no evidence for the existence of muricae in this species has yet been presented. Its aperture has been indicated (opera. cit.) as a low arch - one which is atypically low for Gorbachikella, but which is not that of Globuligerina. SEM study of better specimens is necessary before the reference of "G." meganomica to Gorbachikella rather than to Conoglobigerina is certain; it may be that this species is close to an origin of Gorbachikella from Conoglobigerina.

The youngest, firmly dated specimens of Gorbachikella are those which were obtained by Longoria (1974, pl. 11, fig. 14-16) from the Leupoldina cabri zone of the La Peña Formation, northern Mexico. These specimens were incorrectly called "Caucasella hauterivica (Subbotina)" by Longoria (1974, p. 48-49); they lack the surface reticulum of Favusella hoterivica (Subbotina) and should correctly be identified as Gorbachikella kugleri (Bolli) (Plate 2, figs. 1, 2). "Globigerina" kugleri (Bolli, 1959, p. 270, pl. 23, figs, 3-5) was originally described from the Cuche Formation of Trinidad and was believed by Bolli (cit.) to range from the Barremian Toco Formation to the Late Aptian Upper Cuche.

Gorbachikella, with its probable range from Early Callovian to Aptian, is believed to be the direct ancestor of Praehedbergella, becaue the only morphological change required is an extension of the aperture 
to a point beyond the limits of the umbilicus.

Genus Praehedbergella Gorbachik and Moullade, 1973 Praehedbergella tatianae sp. nov. Pl. 3, figs. 1-3.

Hedbergella sp. cf. H. sigali Moullade, Longoria, 1974, p. 68 , pl. 22, figs. $1-5$.

Hedbergella cf. H. sigali Moullade, Obata et al., 1982, p. 156 , pl. 4 , figs. $2 \mathrm{a}-\mathrm{c}$.

Type locality and horizon. Speeton Cliff, Filey Bay, North Yorkshire; Late Aptian, Upper Leupoldina cabri zone (sample 8103).

Holotype. BMNH. P52131.

Material. BMNH. P52130.

Derivation of name. In honour of Tatiana N. Gorbachik of Moscow State Lomonosov University.

Description. The test consists of about two whorls of chambers, $4 \frac{1}{2} 2$ chambers in the first whorl and 4 in the final whorl. The spiral side is almost flat; the umbilical side is more convex and has a narrow, deep umbilicus which is in breadth equal to about $1 / 8$ th of the test diameter. The chambers become reniform and depressed with growth, to become about half as high as long when seen on the spiral side. The aperture is a narrow slit, umbilical to extraumbilical, nearly but not quite reaching the periphery of the previous whorl, and is furnished with a porticus which is broadest at its umbilical end. The surface of the test is smooth and nonmuricate: it is uniformly microperforate, the microperforations being about $0.6 \mu \mathrm{m}$ in diameter but often broadened at their outer ends (through test erosion) to about $1.5 \mu \mathrm{m}$.

Test erosion (Plate 3, fig. 1b) also shows how the perforations are the external openings of canaliculi, which have erosion-resistant granular walls (analogous to those of benthic rotalines as described by Banner and Williams, 1973). Early stages of test surface dissolution (Pl. 3, fig. 2b) also reveal the sutural margins between adjacent canalicular walls (compare Banner and Williams, 1973, pl. 2).

Remarks. In spiral view, the chambers of $P$. tatianae are symmetrical anterio-posteriorly (i.e. are broadest at their midpoint), in contrast to $P$. tuschepsensis (Antonova), the type species of the genus, for which a topotype was imaged in SEM by Gorbachik (1986, pl. 15, fig. 1). $P$. tuschepsensis is recorded from the Barremian of the Caucasus (Antonova et al., 1964) and the Early Barremian of Azerbaidzhan (Ali-Zade and Khalilov, 1986). "Hedbergella" sigali Moullade was originally described from the Early Barremian to Early Aptian, as differing from "primitive" forms of Hedbergella delrioensis by its smaller, less coarsely perforate test with a less rugose surface. These criteria, together with the Early Barremian to Early Aptian range of the species, suggests that " $H$." sigali should be referred to Praehedbergella, but primary types or topotypes need detailed restudy before this can be made certain. In any case, $P$. tatianae is readily distinguished from " $H$." sigali by its depressed reniform chambers, shallow sutures and flat spiral surface. Similar small specimens, with characteristically reniform and depressed chambers, have been obtained from the Gargasian stratotype (Globigerinelloides ferreolensis zone) by Longoria (1974). They were recorded by him as "Hedbergella cf. sigali". Obata et al. (1982) have also illustrated specimens referable to $P$. tatianae from the Early Late Aptian of Japan. The anomalously young (Aptian) record of $P$. tuschepsensis by Antonova et al. (1974) may also refer to P. tatianae.

\section{Explanation of Plate 2}

Cretaceous Favusellacean genera, and phylogenetically primitive Praehedbergellidae.

Figs. 1-2. Gorbachikella kugleri (Bolli) gen. nov., figure 1, × 154, from La Peña Formation, Leupoldina cabri zone, early Late Aptian, Northern Mexico (after Longoria, 1974); figure 2, ×98, holotype (after Bolli, 1959), Barremian, Cuche Formation, Trinidad.

Figs. 3-4. Ascoliella scotiensis gen. nov., sp. nov., Oneida well 0-25, Scotian Shelf, off Nova Scotia (after Ascoli, 1976): 3 , peripheral view $\times 130 ; 4$, umbilical view, $\times 110$ (holotype).

Fig. 5. Conoglobigerina gulekhensis (Gorbachik and Poroshina), wall surface $\times 2,100$, showing the beginnings of discontinuous reticulation (after Gorbachik and Poroshina, 1979, fig. 16), Early Berriasian, S.E. Caucasus.

Fig. 6-7. Favusella washitensis (Carsey), Paw Paw Formation (HTL 286), Washita group, Grayson County, Texas, Early Cenomanian. $6 \mathrm{a}$, whole specimen, $\times 110,6 \mathrm{~b}$, reticulations with microperforations, $\times 640,6 \mathrm{c}$, umbilicus, $\times 2275 ; 7$, peripheral view, $\times 105$. (BMNH P52138-39).

Figs. 8-13. Praehedbergella grigelisae sp. nov., figures 8, 11-13, from sample 8109, Leupoldina cabri zone, Speeton Cliff; figures 9 and 10 from sample 8106, upper L. cabri zone, early Late Aptian, Speeton Cliff, North Yorkshire. $8 \mathrm{a}$, whole specimen, $\times 290 ; 8 \mathrm{~b}$, detail of microperforations $\times 2,275 ; 9, \times 260 ; 10, \times 255 ; 11$, holotype, $\times 210 ; 12, \times 335 ; 13, \times 280$. (BMNH P52129 (holotype), P52111-15 (paratypes)). 


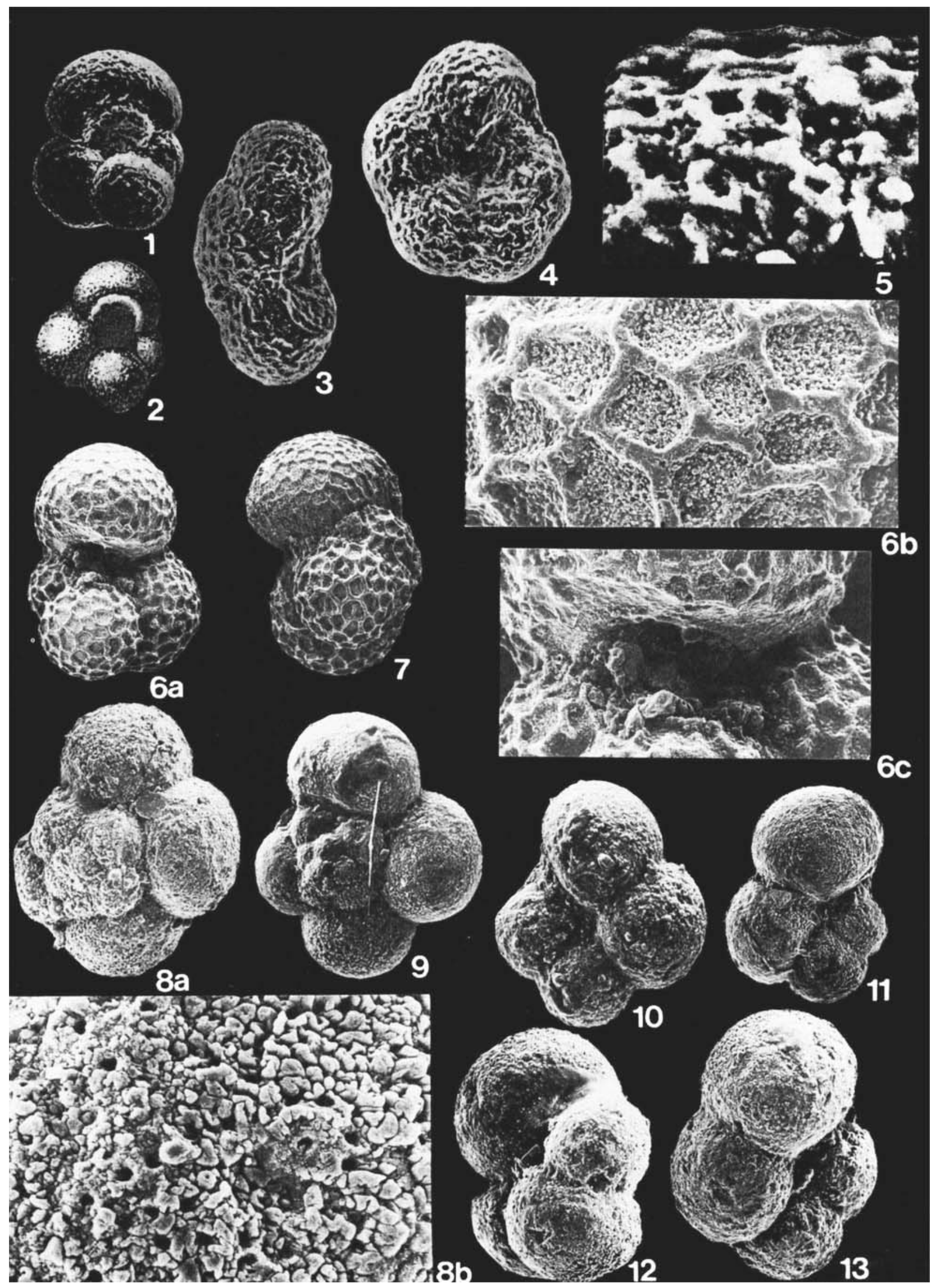


"Caucasella" handousi Salaj (1984), from the Early Hauterivian of Tunisia, possesses an umbilicalextraumbilical aperture and is probably the oldest known species of Praehedbergella; it has much less depressed chambers and a wider umbilicus than $P$. tatianae.

Praehedbergella grigelisae sp. nov. pl. 2, figs. 8-13.

Globigerina sp. 1 Obregon, 1959, p. 150, pl. 3, fig. $7 a-b$.

Holotype BMNH P52129.

Material. BMNH P52111 - 52115.

Derivation of name. This species is named in honour of Algimantas Grigelis, Lithuanian Scientific Research Geological Institute, in recognition of her researches into Jurassic-Cretaceous planktonic foraminifera.

Type locality and horizon. Speeton Cliffs, Filey Bay, North Yorkshire; Late Aptian, Leupoldina cabri zone (Sample 8109).

Description. The test consists of about two and a half whorls of chambers, with about five chambers in the first whorl, reducing to four and a half to four in the final whorl. The spiral side is gently convex, with clearly depressed sutures between the inflated chambers; the intercameral sutures are radial and are in length about half the chamber height. The umbilical side is more convex and has a narrow deep umbilicus, which in breadth is equal to about $1 / 7$ of the test diameter. The chambers become slightly depressed with growth to become about $4 / 5$ as high as long when seen on the spiral side. The aperture is a narrow slit, extending from the umbilicus to the periphery of the previous whorl, and is furnished with a porticus which is broadest at its umbilical end. The surface of the test is smooth and nonmuricate; it is uniformly microperforate, the microperforations being about $1.0 \mu \mathrm{m}$ in diameter.

Remarks. $P$. grigelisae differs from $P$. sigali (Moullade) (Hedbergella sigali Moullade, 1966) in its more depressed chambers, which enlarge more rapidly when seen in umbilical view, and in having a narrower umbilicus, and less deeply depressed sutures. It may be a Late Aptian direct descendant of $P$. sigali (type horizon Lower Barremian, but recorded by Moullade as high as Early Aptian).

The chambers of $P$. grigelisae are much higher and less reniform than those of $P$. tatianae n. sp., a species with which there appears to be no intergradation.

Genus Blefuscuiana gen. nov.

Type species. Blefuscuiana kuznetsovae sp. nov. Derivation of name. Blefuscuiana is named in distinc- tion from Lilliputianella $\mathrm{n}$. gen. and derives its name from the miniature ovoids of Blefuscu (Swift, 1726) which were displayed at their bluntly rounded ends. Diagnosis. Test a low trochospiral of two or more whorls, typically with six or seven chambers in the final whorl, but there may be as few as five or as many as eight. The chambers are subglobular or depressed, reniform or ovoid; they are not radially elongate; spiral side evolute, umbilical side partly involute; aperture intra-extraumbilical, reaching to or even slightly over the periphery of the earlier whorl; the aperture possesses a porticus, of uniform breadth throughout or broadest posteriorly; relict apertures and portici are usually visible in the umbilical parts of the chambers of about half of the last whorl. The wall is microperforate and its surface is smooth, lacking muricae.

Remarks. Any examination of the stratigraphic record will show that planktonic assemblages older than Albian are characterised by a diversity of hedbergellidlike species which are small and microperforate and smooth, in contrast to the assemblages of species of true Hedbergella, especially in Albian and younger Cretaceous strata (e.g. Plate 3, figs. 6-9) which are macroperforate and distinctly muricate over much or all of their test surface. Topotype specimens of Hedbergella trochoidea (Gandolfi) (Longoria, 1974, pl. 17; Masters, 1977, pl. 25) illustrate that the type species of Hedbergella Brönnimann and Brown possesses perforations of $4-8 \mu \mathrm{m}$ in external diameter, whereas species of Blefuscuiana have comparable diameters in the $0.8 \mu \mathrm{m}-1.6 \mu \mathrm{m}$ range. The macroperforations of Hedbergella, like its muricae, can be seen clearly with a good stereo-microscope and the microperforations of Blefuscuiana cannot. Of course, these characters can be seen only in clean specimens and those which have not been diagenetically altered: e.g. Hedbergella planispira Tappan, as illustrated by Michael (1972, pl. 2, figs. 10-12) has chamber surfaces obscured by a smooth calcareous, secondary deposit from the calcareous mudstones of marls of the Duck Creek Formation matrix, whereas clean specimens from the Grayson (e.g. Masters, 1977, pl. 24 fig. 3) and from the Del Rio (Plate 3, figs. 8-9) show the muricae and perforations clearly.

Records of Hedbergella from strata dated as Barremian (e.g. by Gorbachik, 1986, p. 93-95) probably refer to Praehedbergella (e.g. Praehedbergella sigali (Moullade)) or to primitive Blefuscuiana, or to forms morphologically intermediate between these two genera. An example of the last is Blefuscuiana eocretacea (Neagu), an index fossil for the later part of the Early Barremian (Sigal, 1977, p. 104), whose first stratigraphical appearance immediately follows that of Praehedbergella sigali (Sigal, op. cit.) and from which it is probably directly descended. The only difference between $B$. eocretacea and $P$. sigali is the increased 
number of chambers (from 4 to 5) in the last whorl. "Hedbergella (Clavihedbergella) sp. aff. simplex" of Moullade (1966, pl. 8, figs. 18-20), from the Early Barremian of the Haut-Alps, is believed by Sigal (1977) to be the same as $B$. eocretacea, and we agree with this. $B$. eocretacea was also recorded by Sigal $(1979, \mathrm{pl} .1$, figs. 30-31) from the Barremian of DSDP, site 398, Western North Atlantic. The later chambers of the species are as high as broad, as in true Praehedbergella sigali, but they are not sufficiently elongate to justify its inclusion in Lilliputianella.

By Late Aptian time, a diversity of species of Blefusciana was well established. On some species (PI. 3, figs. 4, 5, 5a) and "Hedbergella cf. aptica (Agalarova)" of Gorbachik (1986, pl. 14, figs. 4 and 5, pl. 15, figs. 1 and 2) from the "Middle" Aptian, perforation cones are developed over the microperforations; this structure is not known again in the history of the Globigerinina until they reappear in the heterohelicids Guembelitria (Smith and Pessagno, 1971, pl. 1, figs. 1, $3,5,8)$, of the Maastrichtian, and Cassigerinella $(\mathrm{Li}$, 1986) of the Oligocene. Li (op. cit., p. 61) maintained that, in the latter case, the smooth, microperforate Cassigerinella chipolensis was specifically distinct from C. boudecensis with perforation-cones ("pore-cones"), because their apertures were also distinguishable. However, there is, as yet, no evidence to decide whether or not Blefuscuiana aptica (PI. 5, figs. 4-7), with its smooth, microperforate wall, is a distinct species or merely a phenotype of $B$. cf. aptica $(\mathrm{Pl}$. 3, figs. 4-5) with its perforation cones. No other species of Blefuscuiana has yet been found to possess these structures, but care must be taken, in optical microscopy, to distinguish between such cones and true muricae. The perforation cones seem to be projecting extensions of the microgranular walls of the canaliculi (as seen in eroded specimens of Praehedbergella tatianae, described above). They are secondarily thickened by the addition of shell lamellae during test growth (Pl. 3, fig. 5a) and may be large and sealed on the spiral side of early whorls.

Nevertheless, smooth species of Blefuscuiana dominate the Aptian; many of the Aptian species called "Hedbergella" and "Loeblichella" by Longoria (1974) are referable to Blefuscuiana. Most Aptian species of Blefuscuiana are low spired, and some even become slighly concave on the spiral side; this can lead to an encroachment of the interiomarginal aperture slightly on to the spiral side, and this extension may remain incompletely closed by the last formed chambers in some specimens. While this recalls the gross morphology of muricate, macroperforate, true Loeblichella of the Late Cretaceous, the two genera are distinct, phyletically and stratigraphically.

Species of Blefuscuiana are normally much smaller than those of Hedbergella (just as Tenuitella is charac- teristically smaller than Paragloborotalia in the Tertiary), so it is probable that small Blefuscuiana species have been ignored in routine micropalaeontological analysis when large and abundant Hedbergella spp. are present. Records of species referable to Blefuscuiana are rare after the Albian, but they occur in the Late Cretaceous. For example, "Hedbergella crassa Bolli" of Caron (1978, pl. 11, figs. 5-6, reproduced here PI. 10, figs. $9 a-b)$ appears to have the characteristics of Blefuscuiana, although it was retrieved from Late Coniacian sediment. Generically, it appears indistinguishable from Early Danian species which were referred to "Globorotalia (Turborotalia)" by Blow (1979) (reproduced on $\mathrm{Pl}$. 10, figs. 10a-b). Therefore it is possible that Blefuscuiana provided a root-stock of long geological duration, which was the source of the true Hedbergellidae and their descendants in the Albian and Later Cretaceous, and then again became the progenitors of part at least of the Paleocene Globigerinina.

Although the microperforations of Blefuscuiana are characteristically very much smaller (even to one order of magnitude) than in Hedbergella, the distances between the perforation centres may not differ greatly between species referable to the two genera. That is, the separation distances between the perforations in Blefuscuiana are much greater relative to the perforation diameters than in Hedbergella. This means that the test porosity in Blefuscuiana may be an order of magnitude smaller than in Hedbergella, and the perforations of Blefuscuiana may be much more irregularly distributed on any one part of the test surface.

The total absence of muricae over the test surface of Blefuscuiana means that muricocarinae could never develop. Therefore, although Praeglobotruncana could evolve from Hedbergella, Blefuscuiana was unable to follow an analogous evolution. No imperforate peripheral bands are known in any species of Blefuscuiana, although imperforate areas could develop (apparently sporadically) around the umbilical margins of some species (a character not yet known in Hedbergella or Praeglobotruncana). Evolution of gross morphology, where it was unaffected by the lack of muricae, could and did occur along lines analogous to those of the Hedbergellidae, resulting in gross homeomorphs between the two families (see below, compare Lilliputianella with Clavihedbergella, Blowiella with Globigerinelloides, etc.).

True Hedbergella appears to evolve in the Late Aptian with species such as that recorded as " $H$. delrioensis (Carsey)" by Longoria (1974, pl. 13, figs. 15-18). H. trocoidea (Gandolfi), the type species of Hedbergella, appears slightly later in the Late Aptian (Longoria, 1974; Caron, 1985), and could be its direct descendant. Such forms are both macroperforate and muricate. However, macroperforate but not truly 
muricate species of Hedbergella occur in the Late Albian (e.g. Hedbergella punctata Michael, 1973; H. intermedia Michael, 1973; H. modesta (Bolli) of Sigal, $1979 ;$ H. globigerinelloides (Subbotina) of Sigal, 1979), and some of these probably represent direct descent from microperforate, smooth immediate ancestors (e.g. the true "H." modesta (Bolli, 1959) and " $H$." globigerinelloides (Subbotina, 1949) which are smooth, microperforate and referable to Blefuscuiana).

It is difficult to be sure of the identity of some of the senior species if their types or topotypes have not been reillustrated using SEM, and a particular problem arises with the nature of "Globigerina" gaultina Morozova, 1948. This species, from the Lower Albian, was described originally as having a matt, finely perforate test surface, and it therefore might be congeneric with Blefuscuiana. However, authoritative subsequent authors (e.g. Subbotina, 1953, p. 167, 170, and Masters, 1977, p. 470-473) have identified Morozova's species as a macroperforate, muricate form. Therefore, it is probable that it should be referred to as Hedbergella gaultina (Morozova), and that the genus founded upon it (Planogyrina Zakharova-Atabekyan, 1961) is a synonym of Hedbergella and not of Blefuscuiana.

A similar problem of identification, although without implication for generic nomenclature, could have arisen with "Globigerina" planispira Tappan, which was originally described (Tappan, 1940, p. 122) as possessing a smooth surface, but which topotypes (e.g. Master, 1977 , p. $470-473$, pl. 24, figs. 2, 3, 5) have shown to be muricate and macroperforate (Plate 3, figs.
8, 9). Masters (loc, cit.) considered "Globigerina" gaultina Morozova to be a junior synonym of " $G$." planispira Tappan.

The test walls of Blefuscuiana and Hedbergella are lamellate, new lamellae being added to the test with each chamber addition. It is possible for diagenesis or extraction from the matrix to destroy or remove part of all of the outer lamellae (as in Favusella, see Butt, 1979, pl. 3, and as in Praehedbergella, see Rösler et al. 1979, pl. 2). In such a case, the muricate part of the wall in Hedbergella may be partly removed, leaving a smooth inner lamella similar to the wall of Blefuscuiana. However, total destruction of the outer lamella without leaving traces or without damaging the inner parts of the wall is unlikely ever to occur; even if it did, Blefuscuiana can still be distinguished from Hedbergella by its microperforations.

\section{Blefuscuiana kuznetsovae sp. nov. Pl. 3, fig. 10 (holotype); pl. 4, figs. 1-4.}

Derivation of name. In honour of K. I. Kuznetsova, Academy of Sciences of the U.S.S.R., Geological Institute, Moscow, in recognition of her researches into Jurassic-Cretaceous planktonic foraminifera.

Type locality and horizon. Speeton Cliffs, Filey Bay, North Yorkshire; Late Aptian, Upper Leupolidina cabri zone (Sample 8103).

Description. Test a low trochospire, completely evolute and flat or slightly concave on the spiral side, with six to eight chambers in the last whorl. On the spiral side,

\section{Explanation of Plate 3}

\section{Praehedbergellidae compared to Hedbergellidae.}

Figs 1-3. Praehedbergella tatianae sp. nov., all from sample 8103, upper L. cabri zone, early Late Aptian, Speeton Cliff. 1a (holotype), dorsal view, $\times 250,1 \mathrm{~b}$, surface detail with microperforations (centre), and (top) eroded test surface with the walls of canaliculi projecting, $\times 1,210 ; 2$ a (holotype), umbilical view, $\times 250 ; 2 b$, detail of microperforate, smooth surface, showing etching of the sutures betwen the granular walls of adjacent canaliculi, $\times 1,720 ; 2$, paratype, $\times 250$. Praehedbergellidae, microperforate, smooth. (BMNH P52131 (holotype), P52130 (paratypes)).

Figs. 4-5. Blefuscuiana cf. aptica (Agalarova), with perforation cones, Otto Gott pit, Sarstedt, south of Hannover, F. R. Germany, Lower Saxony Basin; sample 0G60, Acanthoplites nolani zone (Mutterlose, 1985), "Lower Clansayesian", Latest Aptian. 4, umbilical view, $\times 240 ; 5 \mathrm{a}$, dorsal view showing closed perforation-cones in the early whorls, $\times 245 ; 5 \mathrm{~b}$, penultimate chamber showing detailed construction of the perforation-cones, $\times 1,145$ (cf. plate 5, figures 4-7). Praehedbergellidae, microperforate, non-muricate. (BMNH P52102-03).

Figs. 6-7. Hedbergella delrioensis (Carsey), Grayson Formation, Duck Creek, Texas (sample HTL 119), earliest Cenomanian. $6 \mathrm{a}$, whole specimen, $\times 80 ; 6 \mathrm{~b}$, detail of wall with muricae, $\times 120$. Hedbergellidae, muricate. (BMNH P52158-59).

Figs. 8-9. Hedbergella planispira (Tappan), Del Rio Formation, Shoal Creek, Austin, Texas, probably earliest Cenomanian. $8 \mathrm{a}$, dorsal view with muricae on early chambers, $\times 170 ; 8 \mathrm{~b}$, detail, $\times 625 ; 9$, umbilical view with heavy muricae, $\times 140$. Hedbergellidae, muricate. (BMNH P52156-57).

Fig. 10. Blefuscuiana kuznetsovae sp. nov., holotype, sample 8130, upper L. cabri zone, Speeton Cliff. 10a, $\times 190$; $10 \mathrm{~b}$, detail of surface of last chamber, $\times 1,880$. Praehedbergellidae, microperforate, smooth. (BMNH P5209). 

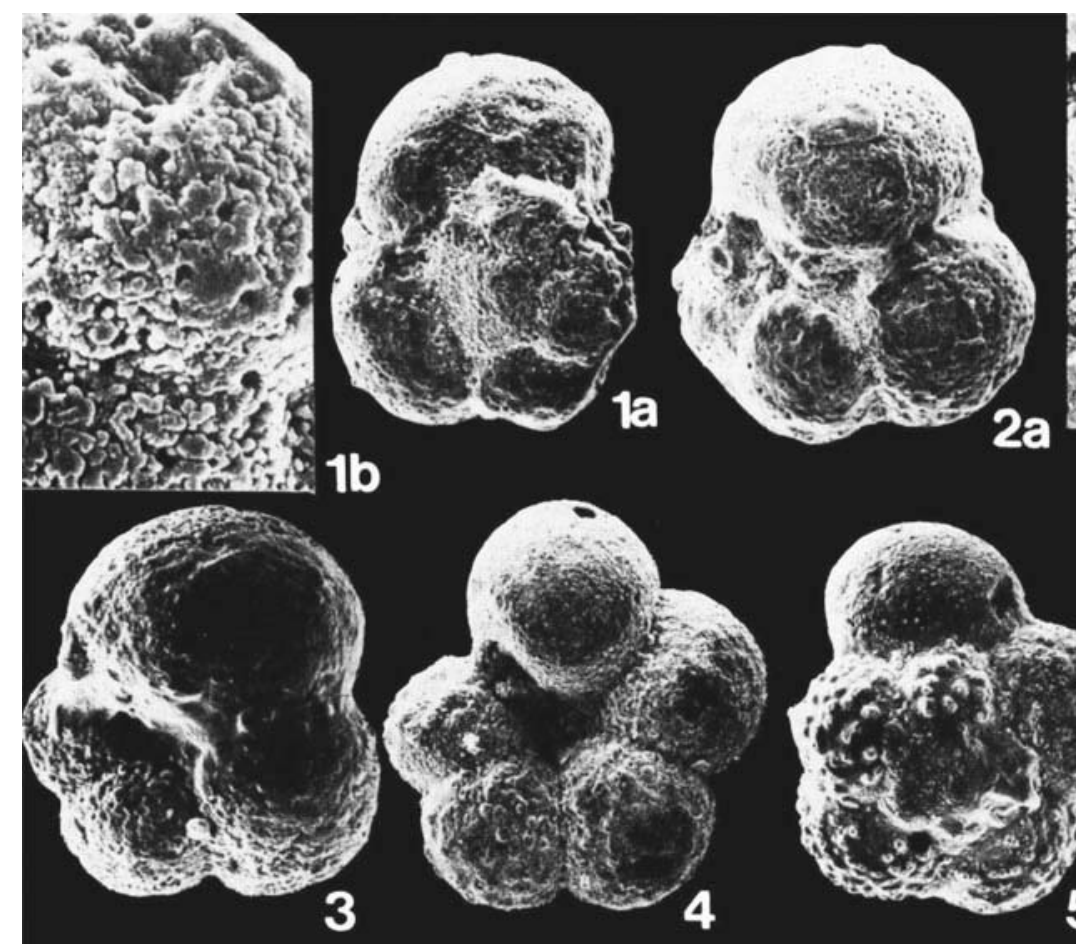

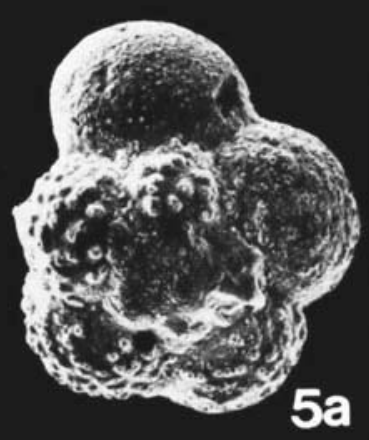

$5 a$

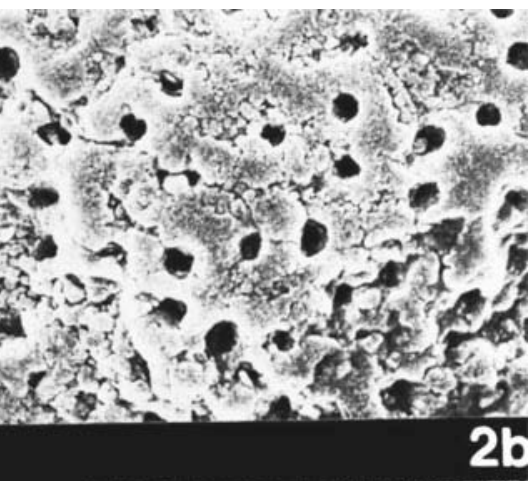

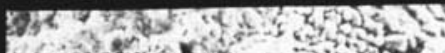

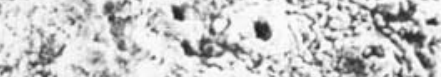

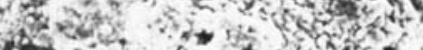
$35-50$ of 2

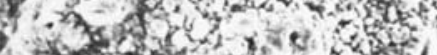

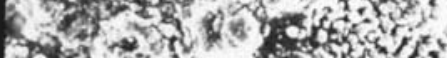
Whent and $x+35$

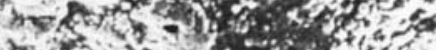

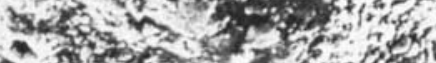

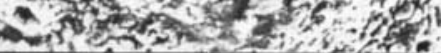

17y

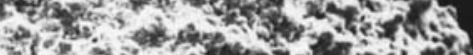

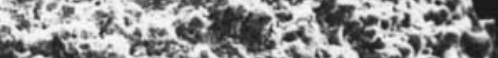

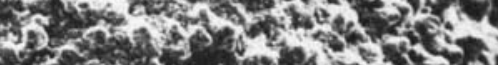

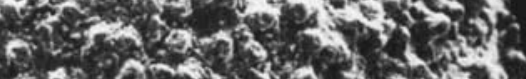

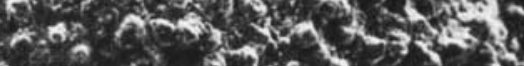

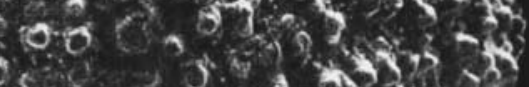

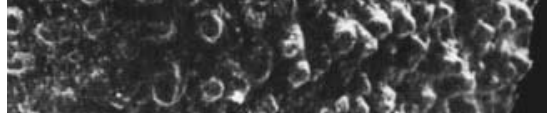

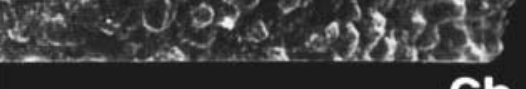

Ty $6 b$ 4. - गु

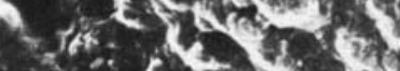

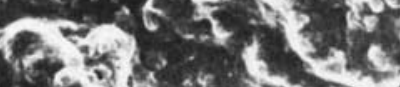

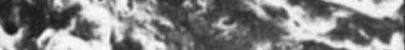

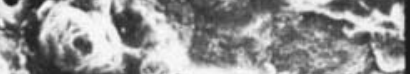
olsens a.

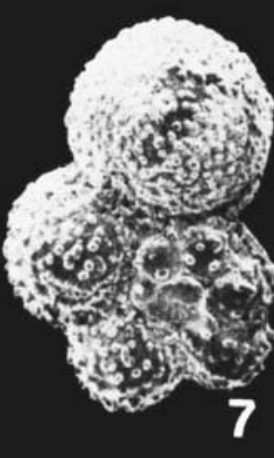
56
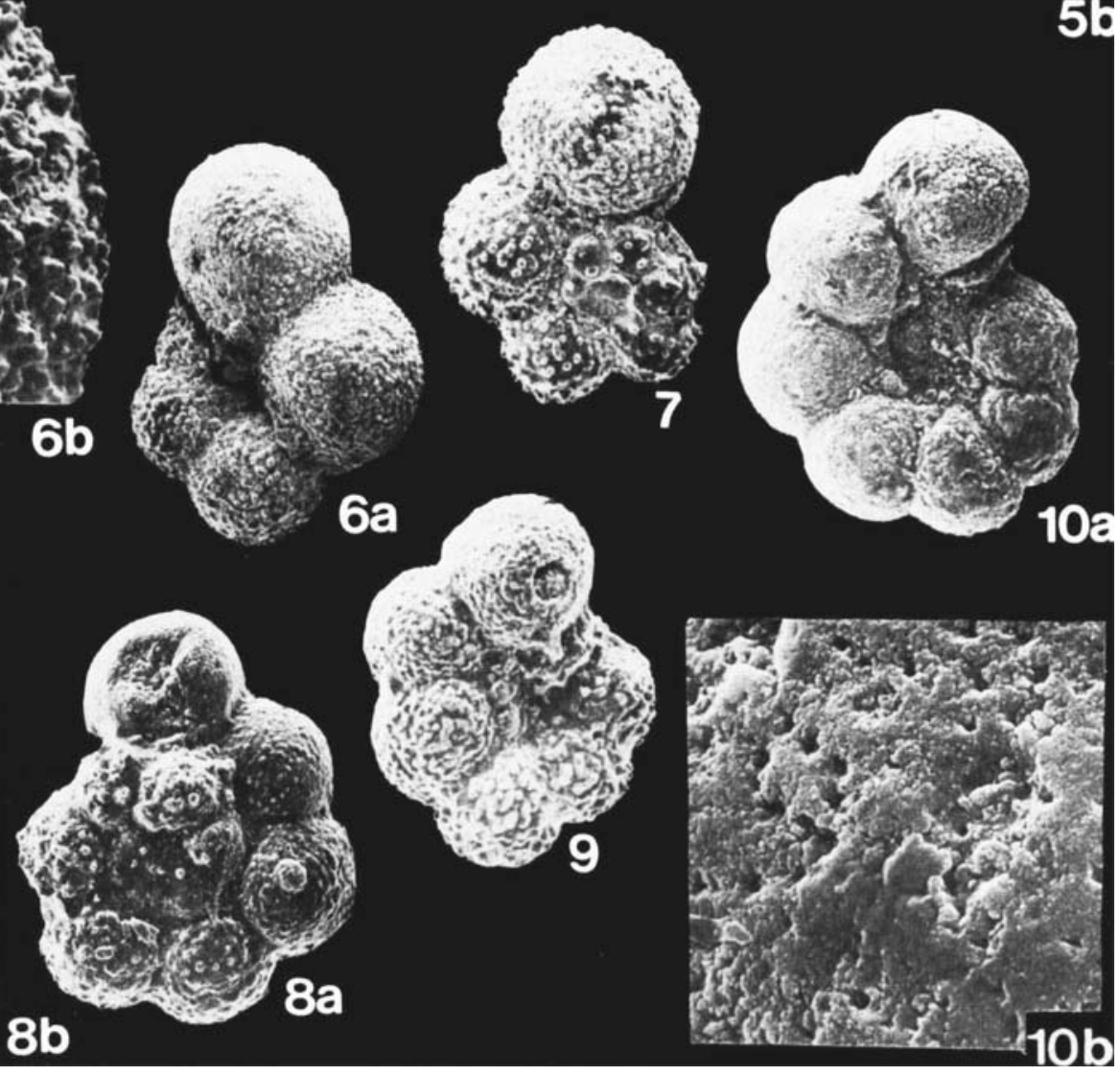
chambers are inflated, subglobular, approximately as high as long, intercameral sutures being depressed and radial or very slightly oblique. The spire opens slowly; on the spiral side the test diameter is $2.5-2.8$ times the height of the last formed chamber. The umbilicus is broad (about 0.27 of the test diameter) and shallow; on this side, the sutures are depressed and radial. The aperture is a low arch, from the umbilicus to the periphery of the penultimate whorl, with a distinct porticus which broadens slightly posteriorly; discrete relict apertures and their portici are open for at least half of the last whorl. The wall is smooth and microperforate, the external openings of the perforations being $0.6-0.7 \mu \mathrm{m}$ in diameter, spaced at $1.3-5$ $\mu \mathrm{m}$ distances.

Remarks. B. kuznetsova differs from B. globigerinelloides (Subbotina) (Globigerina globigerinelloides Subbotina, 1949, Early Albian, Caucasus) in possessing a very much wider umbilicus, with more clearly displayed relict portici (see also Hedbergella globigerinelloides (Subbotina) of Gorbachik, 1989, pl. 18, figs. 2-3). Of all the species described by Longoria (1974), the closest to B. kuznetsovae are some paratypes of "Hedbergella" luterbacheri (e.g. 1974 pl. 19, figs. 21-26); however, the holotype (1974, pl. 26, figs. $15-17)$ is very different, in its possession of long, depressed reniform chambers, a more slowly opening spire (ratio of test diameter to chamber height is about 4.25) and a deeper umbilicus. It is possible that $B$. kuznetsovae has in the past, not been distinguished from these Aptian-Albian species.

\section{Blefuscuiana aptiana (Bartenstein) pl. 5, figs. 1-3.}

?Globigerina sp. D9, Hecht, 1938, p. 17, pl. 23, fig. 60 (holotype).

Globigerina sp. D9, Hecht, 1938, p. 17, pl. 23, figs. 61-63 (paratypes)

Hedbergella aptiana Bartenstein, 1965, p. 347-348, text figs. 3?, 4-6.

Hedbergella aptiana Bartenstein; Sigal, 1979, p. 318, pl. 2, figs. 24,25 .

Remarks. When Hecht (1938) undertook his major study of the foraminiferal biostratigraphy of the N.W. German Early Cretaceous, he informally recorded (as Globigerina sp. D9) a species which first occurred in the Middle Barremian but became very abundant in the Early Aptian. Bartenstein (1965) formally named this species, citing Hecht's figured specimens as the primary type series. Unfortunately, the holotype (Hecht, 1938, text pl. 23, fig. 60, reproduce by Bartenstein (1965) as text fig. 3) appears to be a deformed or abnormal specimen. The paratypes must be used to identify this species. It differs from $B$. kuznetsovae in its much smaller umbilicus (about 0.18 of the test diameter) and, in spiral view, having later chambers which are depressed ovoid (narrower anteriorly).

Sigal (1979) also obtained his specimens from horizons referred to the Early Aptian, but our specimens came from the early Late Aptian of Speeton (L. cabri zone). We are unable to match our specimens with any figured by Longoria (1974) from the Late Aptian of Spain and Mexico.

\section{Explanation of Plate 4}

Praehedbergellidae and Schackoinidae compared to Hedbergellidae and Planomalinidae.

Figs. 1-4. Blefuscuiana kuznetsovae sp. nov., paratypes, 6-7 chambered forms, all from sample 8103, upper L. cabri zone, Speeton Cliff, North Yorkshire; 1, × 195; 2, $\times 195 ; 3, \times 205 ; 4, \times 165$. Praehedbergellidae, microperforate, smooth. (BMNH P52093-96).

Figs. 5-7. Blowiella blowi (Bolli), all from sample 8109, L. cabri zone, Speeton Cliff; $5, \times 165 ; 6 \mathrm{a}, \times 130 ; 6 \mathrm{~b}$, details of surface, $\times 2,100 ; 7, \times 195$. Schackoinidae, microperforate, smooth. (BMNH P52148/49).

Fig. 8. Planomalina praebuxtorfi Wonders, holotype, $\times 127$; low S. dispar zone (low Rotalipora appenninica zone), Late Albian, El Burrueco, Spain (after Robaszynski and Caron, 1979). Planomalinidae, macroperforate, muricate.

Fig 9. Planomalina buxtorfi (Gandolfi), $\times 60, S$. dispar zone, upper Gault, Late Albian, Kent, England (after Magniez-Jannin, 1981). Planomalinidae, macroperforate, muricocarinate.

Fig. 10. Clavihedbergella subcretacea (Tappan), $\times 192$, Eagle Ford group, Lake Waco Formation, Choice member, Spring Valley, Texas, Late Cenomanian (after Masters, 1977). Hedbergellidae, macroperforate.

Figs. 11-12. Lilliputianella longorii sp. nov., fig. 11 (holotype), sample 8103, upper Leupoldina cabri zone, Speeton Cliff; 11a, $\times 190 ; 11 \mathrm{~b}, \times 175 ; 11 \mathrm{c}, \times 2,300$. Fig. 12 , sample 8109, L. cabri zone; $12 \mathrm{a}, \times 175 ; 12 \mathrm{~b}, \times 2,500$. Praehedbergellidae, microperforate, smooth. (BMNH, P52116 (holotype), P52117 (paratype)). 


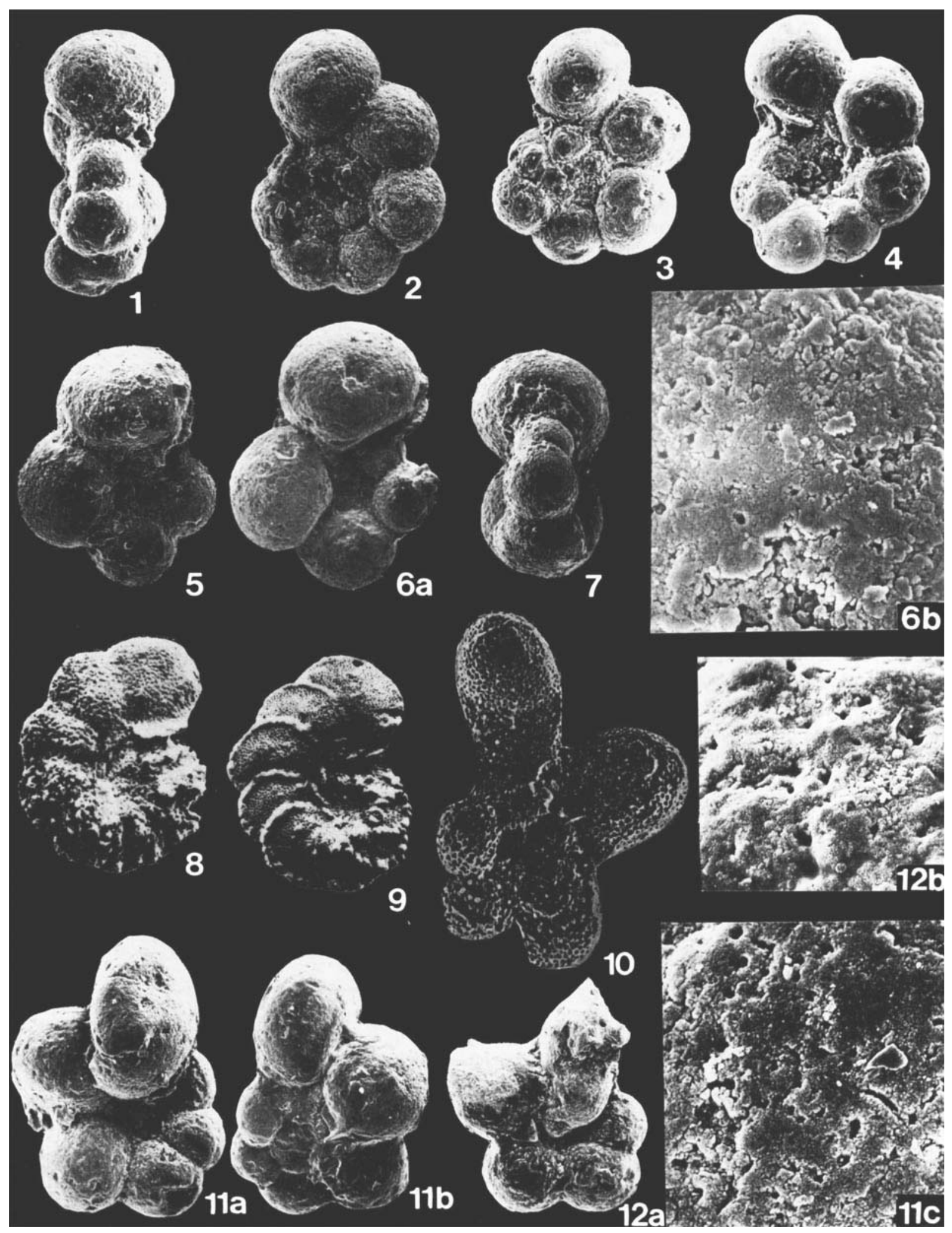


Blefusciana aptica (Agalarova), 1951.

$$
\text { P1. 5, figs. 4-7. }
$$

Globigerina aptica Agalarova, 1951, p. 49, pl. 8, figs. 9-11.

Globigerina infracretacea Glaessner subsp. trochoidea Moullade, 1960, p. 136, pl. 2, figs. 21, 23-25.

Globigerina infracretacea Glaessner subsp. gargasiana Moullade, 1961, new name, p. 214.

Hedbergella aptica (Agalarova); Gorbachik, 1986, p. 94, pl. 14, figs. 2-5.

Remarks. The type specimens of $B$. aptica were obtained by Agalarova (1951) from the Aptian of Azerbaidzhan. It is a species characterised by a very small although deep umbilicus (about 0.1 of the test diameter), with chambers which are long and depressed in spiral view (about 1.6 times as long as high) but ovoid in axial view, the chambers being more inflated on the umbilical side than on the other. Gorbachik (1986) considered the species to range from Barremian to Albian, but the later records may more correctly belong to Hedbergella infracretacea (Glaessner) which is an Albian, muricate, true Hedbergella (Glaessner, 1966). Moullade's (1960) specimens were obtained from the Late Aptian, immediately above the cabri zone of the Upper Gargasian of south-east France. Under the erroneous assumption that his new subspecies trochoidea was congeneric with Hedbergella trocoidea (Gandolfi), Moullade (1961) renamed his taxon gargasiana. As we believe it to be referable to Blefuscuiana and not to Hedbergella, there is no secondary homonymy, but both of Moullade's names appear to be subjective junior synonyms of $B$. aptica (Agalarova). Our specimens were obtained from the cabri zone; Moullade (1961) recorded his forms only from above the cabri zone although it persisted to the top of the Aptian. Typical forms of $B$. aptica were figured by Gorbachik (1986) from beds considered to be Middle Aptian.

Perforation cones, similar to those shown on Plate 3, fig. 5a, have been imaged in SEM for $B$. cf aptica by Gorbachik (1986, pl. 14, fig. 4-5, Mid Aptian). Specimens totally lacking perforation cones also occur (Gorbachik, loc. cit., figs. 2-3). Our specimens from the late Aptian sometimes show weak development of perforation cones, especially on the early chambers of the last whorl. Specimens which have an early growth stage with five chambers per whorl, but which accelerate their rate of chamber addition to produce six chambers in the final whorl, and which have a marked development of perforation-cones (especially on the earlier chambers), were obtained from the upper $L$. cabri zone of Speeton and the latest Aptian of N.W. Germany, and are ilustrated here (Plate 3, figs. 4,5 ) as B. cf. aptica.

\section{Blefuscuiana gorbachikae (Longoria), 1974.}

$$
\text { Pl. 5, figs. 8-12. }
$$

Hedbergella gorbachikae Longoria, 1974, p. 56, 58, pl. 15, figs. 1-16.

NOT Hedbergella gorbachikae Longoria; Longoria and Gamper, 1977, p. 203, pl. 2, figs. 7-12.

Hedbergella gorbachikae Longoria; Caron, 1978, p. 658 , pl. 3, figs. 9-12.

Hedbergella gorbachikae Longoria; Gorbachik, 1986, p. 94 , pl. 16, figs. 1,2 .

Remarks. This species is characterised by the strong umbilically-directed convexity of its chambers, creating a very small and deep umbilicus which the later chambers almost overhang. Initially, in spiral view, the chambers are longer than high, reniform, and five in each whorl (pl. 5, fig. 11) but in some specimens later chambers may shorten, become as high as long, with six in the last whorl (pl. 5, fig. 10). Both forms were included by Longoria (1974, pl. 15) within his paratypes from the Hedbergella trocoidea zone, and we have found the same range of variation to occur in a single sample from the Leupoldina cabri zone. Longoria

\section{Explanation of Plate 5 \\ Blefuscuiana spp (Praehedbergellidae).}

Figs. 1-3. Blefuscuiana aptiana (Bartenstein), all from sample 8103, upper $L$. cabri zone, Speeton Cliff. $1, \times 215 ; 2 \mathrm{a}$, detail of surface, $\times 2,100 ; 3, \times 200$. (BMNH P52082-84).

Figs. 4-7. Blefuscuiana aptica (Agalarova), figs. 4-6, from sample 8130 ; fig. 7, from sample 8106; both samples from upper $L$. cabri zone, Speeton Cliff; $4 \mathrm{a}, \times 285 ; 4 \mathrm{~b}$, detail $\times 2,275 ; 5 \mathrm{a}, \times 215 ; 5 \mathrm{~b}$, detail showing early surface erosion with perforation enlargement and early etching of sutures between canalicular walls $\times 2,190 ; 6, \times 215 ; 7$, $\times 270$. (BMNH P52098-52101).

Figs. 8-12. Blefuscuiana gorbachikae (Longoria), all from sample 8109, L. cabri zone, Speeton Cliff; $8 \mathrm{a}, \times 160,8 \mathrm{~b}$, detail, $\times 750 ; 9, \times 160 ; 10, \times 125,11 \mathrm{a}, \times 250,11 \mathrm{~b}$, with partial dissolution loss of the outermost test lamella, $\times 1,800 ; 12, \times 175$. (BMNH P52104-07). 


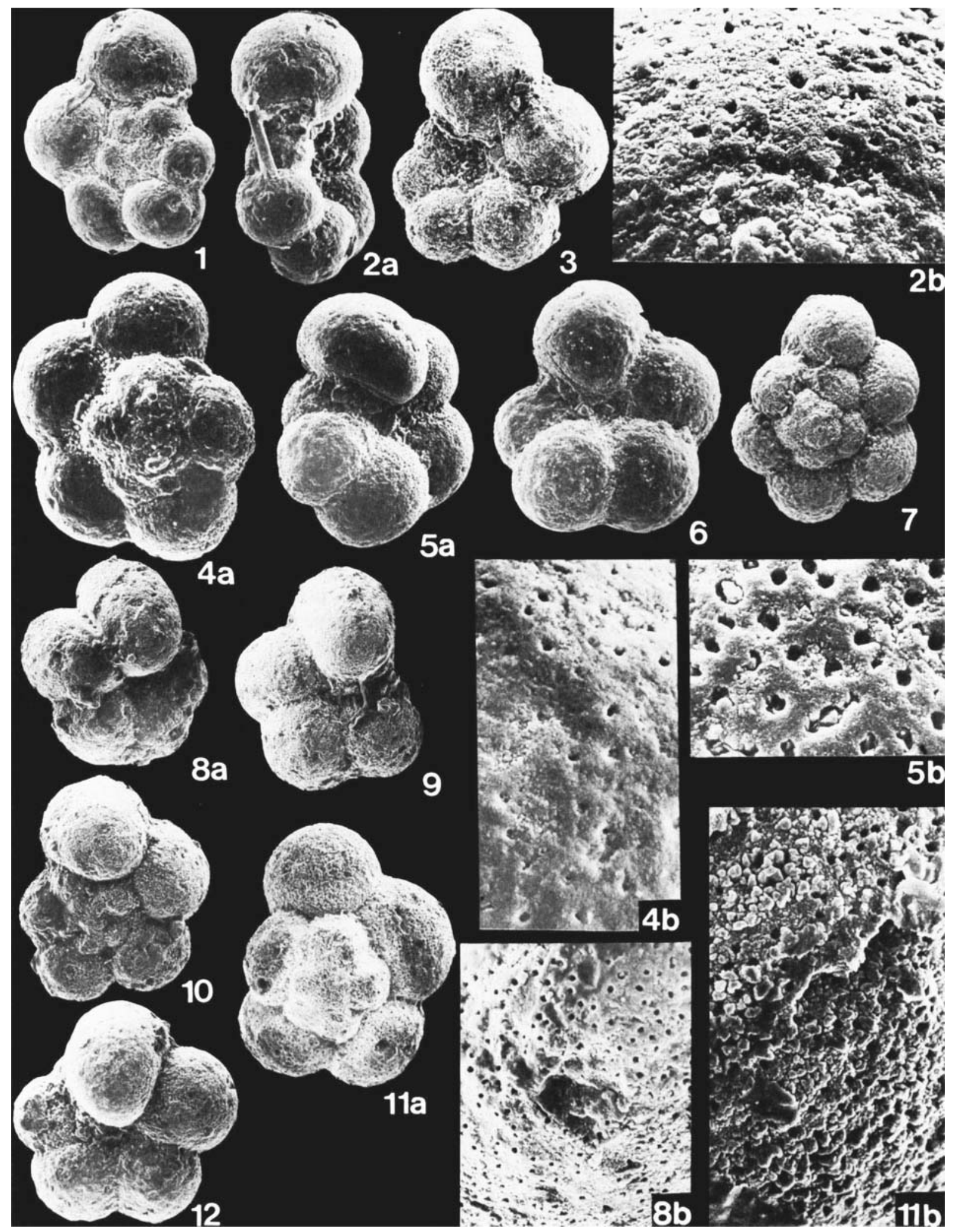


(1974, p. 33) believed the range of the species to be confined to the Latest Aptian to Early Albian (Globigerinelloides algerianus zone and younger) but Gorbachik $(1986$, p. 90, 112) confirms that it is present in "Aptian 2" ("Middle" Aptian) contemporaneously with Leupoldina reicheli, $L$. protruberans and $L$. pustulans (of the cabri zone of Longoria, 1974). B. gorbachikae is believed directly to give rise to Wondersella in the highest Aptian (Banner and Strank, 1987). The records of $B$. gorbachikae from the Albian (Longoria and Gamper, 1977) are of specimens with much less depressed sutures and with less lobulate peripheries than is characteristic of Aptian populations and they may be specifically distinct.

Longoria (1974) stated that the spiral side of $B$. gorbachikae was flattened, but his paratypes (op. cit. pl. 15) include specimens in which the last-formed chambers encroach slightly into the spiral side, making it slightly concave. Both forms are represented in our population from the cabri zone (Pl. 5, figs. 10, 11) where the last chamber may reach or slightly encroach over the periphery of the preceeding whorl (Pl. 5, fig. 10 ). This is an example of a trend towards pseudoplanispirality often seen in species of Blefuscuiana in the Later Aptian (see Blefuscuiana speetonensis n. sp. and Blefuscuiana mitra n. sp.).

Blefuscuiana occulta (Longoria), 1974. Pl. 6, figs. 8-12.

Hedbergella occulta Longoria, 1974, p. 63-64, pl. 11, figs. 1-3, 7-8; pl. 20, figs. 5-7, 8-9, 17-18.

Remarks. This species has six to seven, subglobular to slightly depressed chambers per whorl, with depressed subradial sutures, a flattened to slightly concave spiral side (the height of the last chamber being about $\frac{1}{3}$ of the test diameter), and an open deep, umbilicus (about $25 \%$ of the total test diameter). Longoria's holotype was obtained from the Leuopoldina cabri zone (northern Mexico), and we have obtained specimens from the same horizon at Speeton; Longoria (1974, p. 63) considered the range of this species to extend from the Early Aptian gottisi zone to the lower part of the cabri zone, Late Aptian (the range is incorrectly shown in Longoria's text fig. 8). The specimens called "Hedbergella aff. planispira auct" by Sigal (1976, pl. 2, figs. 1-2), from the Early Aptian, are probably B. occulta. This species is close to Blefuscuiana globigerinelloides (Subbotina), recorded from the Early Aptian to the Albian of the Caucasus, but $B$. globigerinelloides has a very much smaller umbilicus. $B$. occult $a$ almost perfectly honeomorphs Hedbergella modesta (Bolli), the type specimens of which were obtained from the Late Cenomanian; the range of "Late Aptian-Early Albian to top Cenomanian" given by Bolli $(1959$, p. 267) for $H$. modesta may include records of specimens correctly referable to $B$. occulta.

$$
\begin{gathered}
\text { Blefuscuiana occulta (Longoria) quinquecamerata } \\
\text { subsp. nov. } \\
\text { PI. 7, figs. 9-11. }
\end{gathered}
$$

Diagnosis. This subspecies differs from the typical Blefuscuiana occulta (Hedbergella occulta Longoria, 1974 ) in possessing 5 to $5 \frac{1}{2}$ rapidly enlarging chambers in the final whorl, compared to the six to seven chambers per whorl of the typical form of the species. On the spiral side, the height of the last chamber is about $45 \%$ of the total test diameter, compared to about $30 \%$ in B. occulta s. s.

Holotype BMNH P 52092.

Type locality and horizon. Speeton Cliff, $L$. cabri Zone. Remarks. This subspecies has been found by us only in the Leupoldina cabri zone (sample 8109) of Speeton and it has not been recorded yet from higher horizons. It appears not to have been observed by Longoria (1974) in his assemblages from the Middle and Late

\section{Explanation of Plate 6}

Blefuscuiana spp (Praehedbergellidae).

Figs. 1-3. Blefuscuiana globigerinelloides (Subbotina) lobulata $\mathrm{n}$. subsp., all from sample 8109 , Leupoldina cabri zone, Speeton Cliff. Holotype: 1, $\times 180$. Paratype $2, \times 180 ; 3 a, \times 135,3 b$, detail of surface, $\times 2,250$. (BMNH P52085-86).

Figs. 4-6. Blefuscuiana mitra sp. nov., all from sample 8109, L. cabri zone, Speeton Cliff. Paratypes: 4, $\times 185 ; 5$, $\times 250$. Holotype; $6 \mathrm{a}, \times 175,6 \mathrm{~b}$, detail of early whorls $\times 520$. (BMNH, P52089 (holotype), P52087-88 (paratypes)).

Figs. 7a-d. Blefuscuiana multicamerata sp. nov., holotype from sample 8103, upper L. cabri zone, Speeton Cliff. 7a, detail of wall surface, $\times 1,750 ; 7 \mathrm{c}, \times 2,380 ; 7 \mathrm{~d}$, umbilical detail, $\times 430$. (BMNH P52090).

Figs. 8-12. Blefuscuiana occulta (Longoria), figures 8, 10, 11 from sample 8106, upper $L$. cabri zone; figures 9 and 12 from sample 8109, L. cabri zone; Speeton Cliff. $8, \times 135 ; 9, \times 155 ; 10 \mathrm{a}, \times 145,10 \mathrm{~b}$, detail of surface, $\times 3,750$; $11, \times 175 ; 12, \times 160$. (BMNH P52108-10). 


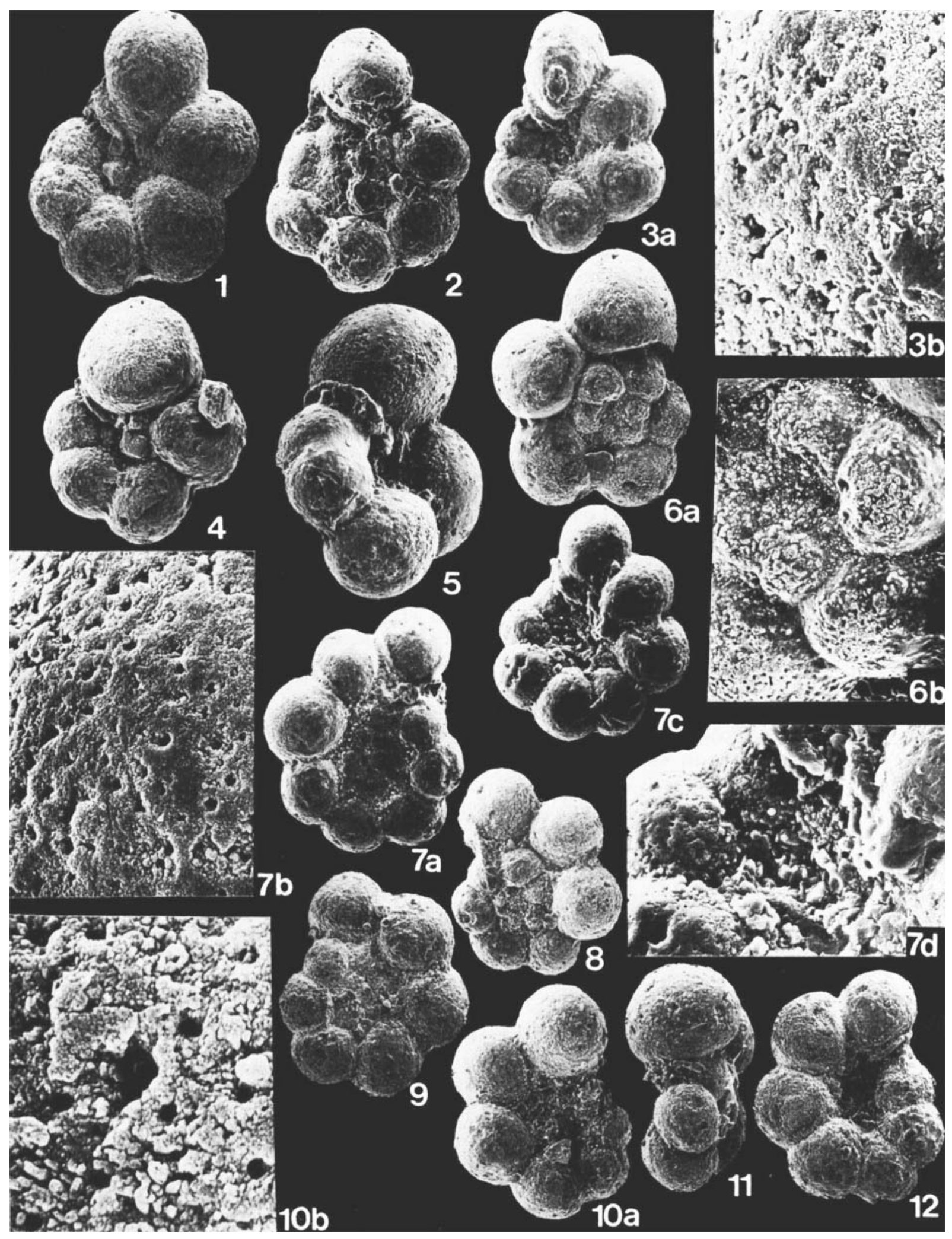


Aptian either of southern Europe or Mexico. It may be restricted to the Boreal realm.

Blefuscuiana globigerinelloides (Subbotina), 1949. Blefuscuiana globigerinelloides (Subbotina) lobulata subsp. nov.

Pl. 6, figs. 1-3.

Diagnosis. This subspecies differs from $B$. globigerinelloides (Globigerina globigerinelloides Subbotina, 1949) in possessing chambers which, in the final whorl, become as high as long, with more deeply indented intercameral sutures and a more lobulate periphery. On the spiral side, the chambers of early whorls are globular to reniform, but as the later chambers become higher, they occupy $38-40 \%$ of the total test diameter (as compared to $30 \%$ in the typical form of the species).

Holotype. BMNH.P52085.

Material BMNH P52086.

Type locality and horizon. Speeton Cliff, L. cabri Zone. Remarks. Blefuscuiana globigerinelloides (Subbotina) s. s. has not yet been found in the Aptian of Speeton, although it was recorded by Subbotina (1949) to range from the upper part of the Early Aptian at least to the lower part of the Early Albian in the Caucasus. Gorbachik (1986) believed that "Hedbergella" globigerinelloides had an even younger range (Late Albian to Cenomanian) but she included in this records of $H$. modesta (Boli, 1959) which she believed to be a junior synonym. We have found $B$. globigerinelloides lobulata only in the upper L. cabri zone of Speeton (Sample 8103).

Blefuscuiana speetonensis sp. nov.

Pl. 7, figs. 1-8.

Hedbergella planispira (Tappan), Longoria, 1974, p. $64-65$, pl. 23 , figs. $5-7,17-18$.

Holotype. BMNH P52075.

Material. BMNH P52076-81.

Type locality and horizon. Speeton Clif, Filey Bay, North Yorkshire; Sample 8109, Leupoldina cabri zone, Late Aptian.

Description. The test is a low trochospire with about six chambers in the first whorl and five to seven chambers in the final whorl. The spiral side is typically wholly evolute and flat (Pl. 7, figs. 1-2) but may become slightly involute and concave (PI. 7, figs. 3-4) with growth or with reduction of chamber number or both.

The intercameral sutures of the spiral side are straight and slightly oblique and become increasingly depressed in the final whorl as the chambers become increasingly globular. The umbilicus is moderately broad (with breadth about $25 \%$ of the test diameter) and open; the intercameral sutures on the umbilical side are virtually radial. On both the spiral and umbilical sides, the initially reniform chambers are broadest toward their posterior ends, this asymmetry giving the earlier chambers a slightly "swept back" appearance, like ovoids with the narrower end to the anterior; the later chambers of the last whorl become subglobular. The aperture is a low arch, in early chambers extending from the umbilicus to the periphery of the previous whorl, but in the later chambers it may extend over the periphery to encroach slightly onto the spiral side. The aperture has a porticus throughout its length, broadest posteriorly. Relict apertures and portici are visible in the umbilicus for about half of the last whorl. The surface of the test is smooth, not muricate, and is microperforate, with external diameters about $0.6 \mu \mathrm{m}$. The whole surface is microperforate except for the umbilical shoulders, which may be imperforate.

Remarks. We are unable to identify this species with any which have been previously described. The specimens called Hedbergella planispira by Longoria (1974) from the late Aptian cabri zone of La Drôme, S.E. France, and from northern Mexico are conspecific with ours, but they are not muricate or macroperforate and are not Hedbergella planispira (Tappan) (compare Plate 3, figures 8-9). The tendency towards planispirality shown by the later chambers of some specimens of Blefuscuiana speetonensis suggest that this species may be ancestral to multi-chambered species of Blowiella recorded from stratigraphically higher horizons of the Late Aptian (e.g. "Globigerineelloides blowi" of Longoria (1974, pl. 4, figs. 4,7 from the ferreolensis zone).

\section{Blefuscuiana mitra sp. nov.

$$
\text { Pl. 6, figs. 4-6. }
$$

?Globigerina infracretacea Glaessner; Obregón, 1959, p. 149 , pl. 3 , figs. $6 a-b$.

Derivation of name. Mitra, a mitre, or turban-like head-dress; with reference to the shape of the last formed chambers.

Holotype. BMNH P52089.

Material. BMNH P52087-88.

Type locality and horizon. Speeton Cliff, Filey Bay, North Yorkshire; Sample 8109, Leupoldina cabri zone, Late Aptian.

Description. The test is a low trochospire with five to six chambers in each of three whorls. The spiral side is evolute and flat; the chambers are normally subglobular, only the last one or two becoming radially subovoid and with increasingly depressed sutures. The intercameral sutures are subradial on both the spiral and 
umbilical sides. The umbilicus has a breadth equal to about $20 \%$ of the test diameter. The aperture is a low arch extending from the umbilicus to the periphery of the previous whorl and extending over it into the spiral suture in the last formed chamber; the aperture has a porticus extending from the umbilicus (where it is broadest) to the periphery, but not beyond it. The surface of the test is smooth and microperforate (external perforations about $0.6 \mu \mathrm{m}$ in diameter); a narrow imperforate zone may be present in the spiral suture where the aperture encroaches on to the spiral side.

Remarks. Like $B$. speetonensis, $B$. mitra shows a tendency towards planispirality in the last few chambers but it is distinguished by its smaller umbilicus, consistently more globular chambers, which are typically fewer in each whorl, and by the high, cowl-like or mitre-like doming of the last chambers (which never leads to elongation as in Lilliputianella).

We have not been able to identify this species with any previously described, but specimens found by Obregón (1959) from the Late Aptian cabri zone of Mexico may be conspecific (they are not referable to Globigerina infracetacea; compare Glaessner, 1966).

Blefuscuiana multicamerata sp. nov.

PI. 6, figs. $7 \mathrm{a}-\mathrm{d}$.

Derivation of name. Multicamerata, many chambers. Holotype. BMNH P52090.

Type locality and horizon. Speeton Cliff, Filey Bay, North Yorkshire; Sample 8103, upper Leupoldina cabri zone, Late Aptian.

Description. Test a low trochospire; spiral side flat or slightly concave, of two or three whorls, with about eight chambers in later whorls; chambers initially reniform and slightly depressed, becoming subglobular with growth. Intercameral sutures are subradial and distinctly but not deeply depressed on both the spiral and umbilical sides. The umbilicus has a breadth equal to about $20 \%$ of the test diameter; it is open and shallow. The aperture is a very low slit extending from the umbilicus to the periphery of the preceding whorl; it is furnished with a narrow porticus which broadens rapidly into a subtriangular flap at its posterior end. Relict apertures and their portical flaps are visible in the umbilicus for about half of the last whorl; the portical flaps are separate and not fused distally. The surface of the test is smooth, and not muricate; it is uniformly microperforate; the external diameters of the microperforations vary from about $0.8 \mu \mathrm{m}$ on the umbilical side to about $1 \mu \mathrm{m}$ on the spiral side.
Remarks. No other known species of Blefuscuiana has as many chambers per whorl as $B$. multicamerata. This, together with its widely open umbilicus, subglobular chambers and lack of a tendency to pseudoplanospirality, distinguishes it from all species described by Longoria (1974) and other authors known to us.

The specimens called "Ticinella aff. bejaouaensis Sigal" by Gorbachik (1986, pl. 20, figs. 2, 3, Early Aptian, Mangishlak) may be related; they are smooth and microperforate, but have fewer chambers, curved intercameral sutures on the spiral side, and long portical flaps. The multichambered last whorls of $B$. multicamerata appear to be parallelled only in certain planospiral species referable to Globigerinelloides (e.g., G. barri (Bolli et al.), G. macrocameratus Longoria, $G$. algerianus (Cushman and tenDam), which do not apper to be directly related to $B$. multicamerata.

Genus Lilliputianella gen. nov.

Type species Lilliputianella longorii sp. nov.

Derivation of name. The generic name Lilliputianella is derived from Lilliput (Swift, 1726) wherein organisms were of small proportions and where ovoids which displayed their pointed ends were preferred.

Description. Test trochospiral, evolute on spiral side, almost wholly involute on umbilical side, composed of two to three whorls of chambers; four to seven chambers in a whorl. The chambers are initially subglobular to reniform, becoming radially elongate and ovoid, and higher than broad, in the final whorl. The aperture is interiomarginal, umbilicalextraumbilical, with a porticus which is typically broadest at its posterior end. The relict parts of the primary aperture, with their portici, are visible on the last few chambers within the open umbilicus. The wall is microperforate, the external perforations being about 0.5 to $1.0 \mu \mathrm{m}$ in diameter and scattered irregularly over the surface of the test with no geometrical pattern of distribution. The surface of the test is smooth and lacks true muricae or spine bases.

Remarks. The radially elongate, pointed ovoid or clavate chambers of the last whorl, in which the chamber height is greater than the chamber breadth, distinguish this genus from both Hedbergella Brönnimann and Brown and from Blefuscuiana $\mathrm{n}$. gen. Lilliputianella (Plate 4, figs. 11-12) is microperforate and nonmuricate and is therefore distinguished from Clavidhedbergella Banner and Blow, which is macroperforate (external perforations an order of magnitude larger and more densely and regularly packed) and which is wholly or partly muricate (Plate 4, fig. 10).

We have not been able to find published records of pre-Aptian species which should be referred to Lillipu- 
tianella. Study of the numerically-rich planktonic foraminiferal assemblages from sidewall cores of the subsurface Kopervik formation, Central North Sea (well dated in BP Petroleum Development Ltd proprietary reports as Early Barremian to Middle/Late Barremian, on palynology and nannofossils) revealed the presence of abundant specimens of Blefuscuiana and rarer Praehedbergella, but none referable to Lilliputianella. Therefore, all evidence available to us suggests that Lilliputianella first appeared during the (Early to Middle?) Aptian.

Lilliputianella spp. appears to have been derived directly from Blefuscuiana spp. by radial elongation of some or all of the chambers of the last whorl. This parallels the independent evolution of Clavihedbergella spp. from Hedbergella ("Planogyrina") in Albian and Later Cretaceous time, as well as the Cenozoic evolution of Clavatorella, Beella, etc.

The radially elongate chambers of Lilliputianella often develop in only the later half of the last whorl (the early whorls being indistinguishable from the ancestral Blefuscuiana) and this parallels the development of radially elongate chambers in the later parts of the last whorl of many forms of Leupoldina (where the juvenile resembles the ancestral Blowiella, e.g. Pl. 10, figs. 1, 2). The pointed ovoid form of elongate chamber, which is so common in species of Lilliputianella (pl. 8, figs. 5-7), gives the appearance of incipient sites for tubulospine development, but no tubulospines are known in any trochospiral schackoinid (they are confined to the planospiral Schackoina).

As in the evolution of Blefuscuiana, no species of Lilliputianella is yet known to extend and distally fuse its portici. The development of umbilical accessory apertures by the fusion of portici seems to be confined to the descendants of macroperforate Hedbergella. Therefore, the macroperforate Clavihedbergella has a rotaliporid relative with accessory umbilical apertures and elongate chambers (Claviticinella digitalis (Sigal)
El-Naggar), but Lilliputianella has no such descendant. It seems that the microperforate descendants of Praehedbergella had only a limited capacity grossly to homeomorph the descendants of macroperforate Hedbergella (the microperforate forms not only lacked the capacity to parallel the evolution of Ticinella, but in being nonmuricate, they never evolved peripheral keels).

A stratigraphically very early tendency radially to elongate later chambers is displayed by some specimens of Praehedbergella illustrated by Butt $(1979, \mathrm{pl} .3$, figs. 11-13). These have only four chambers in each whorl but the last one or two may become as high as long, producing a strongly lobulate peripheral outline. The age of these specimens is disputed, because the nannofossils suggest a Hauterivian age while the foraminifera indicate Barremian (Butt, 1979, p. 257). Such forms are likely to be directly ancestral to Blefuscuiana eocretacea (Neagu) and do not seem to have developed directly into true Lilliputianella.

\section{Lilliputianella longorii $\mathrm{sp}$. nov.} PI. 4, figs. 11-12.

\section{Holotype. BMNH P52116. \\ Material. BMNH P52117.}

Type locality and horizon. Speeton Cliff, Filey Bay, North Yorkshire; Late Aptian, upper Leupoldina cabri zone (holotype, Sample 8103), and lower/middle Leupoldina cabri zone (paratypes, Sample 8109).

Derivation of name. In honour of Jose Francisco Longoria, Mexican Institute of Petroleum Technology and Exploration, Mexico, in recognition of his researches into Aptian-Albian planktonic foraminifera.

Description. The test is a low trochospire with five to six chambers in the last whorl. The last two or three chambers increase rapidly in height to become $1 \frac{1}{2}$ to twice as high as broad in umbilical view, and ovoid in form, being bluntly rounded or pointed conical at their

\section{Explanation of Plate 7 \\ Blefuscuiana and Lilliputianella.}

Figs. 1-8. Blefuscuiana speetonensis sp. nov., all from sample 8109, L. cabri zone, Speeton Cliff. Figs. 1-4, series showing variation in chamber number, spiral side involution and convexity/concavity; figs. 5-7, series showing consistency of umbilical characters with variation in chamber number; fig. 8 , showing encroachment of aperture to umbilical-peripheral position. Fig. 2, holotype, $\times 200 ; 1,3-8$, paratypes, $1, \times 190 ; 3, \times 185 ; 4, \times 210 ; 5$, $\times 200 ; 6 \mathrm{a}, \times 185 ; 6 \mathrm{~b}$, detail of surface, $\times 2,733 ; 7, \times 190 ; 8, \times 195$. (BMNH P52075 (holotype), P52076-81 (paratypes)).

Figs. 9-11. Blefuscuiana occulta (Longoria) quinquecamerata n. subsp., all from sample 8109, L. cabri zone, Speeton Cliff. Figs. 9, holotype, $\times 175 ; 10-11$, paratypes; $10, \times 205 ; 11$, detail of wall of different specimen, $\times 2,200$. (BMNH P52092 (holotype)).

Figs. 12-15. Lilliputianella bizonae (Chevalier), all from sample 8109, Leupoldina cabri zone, Speeton Cliff. 12 , $\times 190 ; 13, \times 135 ; 14 \mathrm{a}, \times 175 ; 14 \mathrm{~b}$, detail, $\times 2,050 ; 15, \times 190 .(\mathrm{BMNH}$ P52127-52128). 


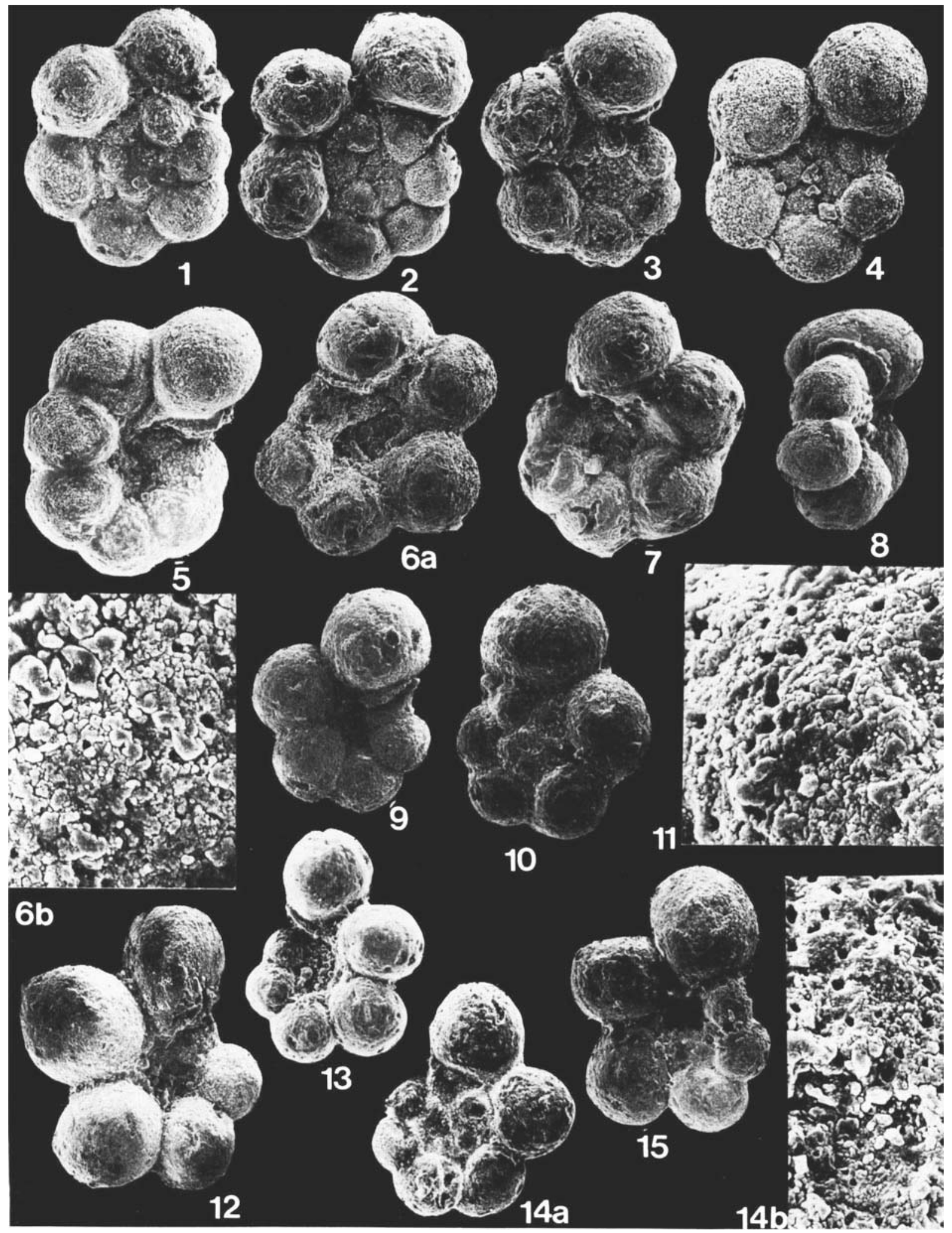


distal ends. The greatest breadth of each chamber is at the distal end of each intercameral suture. On the umbilical side, the intercameral sutures are straight but are slightly oblique to the test radius, especially between the earlier chambers. The umbilicus is deep but narrow, in breadth being about $10 \%$ to $12 \%$ of the maximum test diameter. The umbilical-extraumbilical aperture is a low slit, furnished with a narrow porticus; relict apertures and portici are visible within the umbilicus for the latter half of the final whorl. The surface of the test is smooth except occasionally for irregular, scattered, rounded, blunt pustules around the umbilical margin; the surface is penetrated by scattered perforations of 0.4 to $0.8 \mu \mathrm{m}$ (mostly about $0.6 \mu \mathrm{m}$ ) diameter, distributed irregularly over the test surface.

Remarks. Lilliputianella longorii differs from L. semielongata (Hedbergella semielongata Longoria, 1974, p. 66, pl. 21, figs. 1-5; Globigerinelloides gottisi zone, Early Aptian, to lower Leupoldina cabri zone, earliest Late Aptian, northern Mexico) in its much less elongate, less clavate chambers and smaller umbilicus. L. longorii differs from L. labocaensis (Hedbergella labocaensis Longoria, 1974, p. 60, figs. 7-9, 22-24, from the "Hedbergella" gorbachikae zone to the $H$. trocoidae zone, Latest Aptian, northern Mexico) in its smaller umbilicus.

$L$. longorii does not have the rapid and extreme radial elongation of the later chambers of the last whorl which is so characteristic of Lilliputianella roblesae (Globigerina roblesae Obregón, 1959, p. 149, pl. 4, cabri zone, Mexico).

\section{Lilliputianella bizonae (Chevalier), 1961. Pl. 7, figs. 12-15.}

Hastigerinella aff. subcretacea Tappan; Bolli, 1959, p. 271 , pl. 23, figs. $10,11,13$. (not fig. $12=$ Hedbergella bollii Longoria, 1974).

Hastigerinella bizonae Chevalier), 1961, p. 34, pl. 1, figs. 24-28.

Clavidhedbergella bizonae (Chevalier); Gorbachik, 1971, p. 138 , pl. 30, figs. 4a-b.

Clavidhedbergella bizonae (Chevalier); Kuhry, 1971, p. 231-232, pl. 3, figs. 2a-c.

Clavihedbergella bizonae (Chevalier); Gorbachik, 1986, pl. 26, fig. 3.

Remarks. The species is characterised by inflated chambers with distinctly convex sides, especially on the umbilical side of the test, and with broadly and very deeply depressed intercameral sutures. The chambers become radially elongate and swollen in the latter half of the last whorl, and are distally broadly rounded or broadly pointed: these chambers attain their greatest breadth beyond the limits of the intercameral sutures (unlike L. kuhryi, PI. 8, fig. 5, in which the greatest breadth of each chamber is attained while adjacent chambers are still in contact). L. bizonae characteristically possesses a broad, shallow umbilicus in which relict apertures of at least the last three chambers are visible, and the radial elongation of the chambers in the latter part of the last whorl produces all gradations from highly domed to pointed ovoid within and between tests.

Kuhry (1971, p. 222) reported the range of $L$. bizonae to be within the middle to later parts of the Aptian, S.E. Spain. Chevalier (1961) obtained the type specimens of $L$. bizonae from the early Late Aptian, Lower Gargasian, possibly from the Leupoldina cabri zone. The specimens figured by Bolli (1959) were obtained from the "Leupoldina protuberans zone", "early to middle Aptian", Cuche formation, Trinidad. Gorbachik's specimens came from the Crimea, from the "middle" Aptian (Gorbachik, 1986) and from the Late Aptian (Gorbachik, 1971); the latter are depicted as possessing six chambers in the final whorl, more rapidly enlarging than in the specimens figured in this paper.

Our specimens may be conspecific with those recorded by Caron (1978) as "Hedbergella labocaensis Longoria" (which Caron considered to be a synonym of $H$. similis Longoria, 1974). The chambers of Lilliputianella bizonae are less compressed and more inflated than those of $L$. similis.

Lilliputianella globulifera (Krechmar and Gorbachik), 1971.

Pl. 8, figs. 1-4.

Clavihedbergella globulifera, nomen nudum, Gorbachik and Krechmar, 1971. p. 22, pl. VI, figs. 6 , 7.

Clavihedbergella globulifera Krechmar and Gorbachik, in Gorbachik, 1971. p. 136, pl. 30, figs. 1a-c (holotype).

Clavihedbergella globulifera Krechmar and Gorbachik; Gorbachik, 1986, p. 119, 120 (reference only), pl. 26 , figs. $1-2$.

Remarks. The first publication of this species-name by Gorbachik and Krechmar (1971) lacked description even though an illustration was referred to; it was validated in a subsequent paper (Gorbachik, 1971) and then it was credited to Krechmar and Gorbachik as joint authors.

The primary types were obtained by Krechmar and Gorbachik from the Early and Late Aptian of the Crimea, and Gorbachik (1986) figured specimens from the Middle and Late Aptian of the same area. The primary type series was recorded (Gorbachik, 1971) as specimens possessing five to $51 / 2$ chambers in early whorls and 51/2-7 chambers in later whorls; this agrees with our observations, but we have not been able to 
recognise the microspheric and megalospheric generations believed to occur by the original authors of this species. The wall of this species was stated by Krechmar and Gorbachik (Gorbachik, 1971) to be thin, finely perforate and possibly unilamellar; the roughness of the wall of the Late Aptian specimen subsequently figured by Gorbachik (1986) is probably due to secondary calcite grain-growth during diagenesis.

L. globulifera possesses a deep and open umbilicus, in breadth equal to $1 / 5$ to $1 / 4$ of the test diameter. The chambers become elongate ovoid later in ontogeny than in L. bizonae, L. kuhryi and $L$. longorii and only the last one of two chambers may be distinctly higher than broad.

L. globulifera differs from $L$. similis in possessing a concave spiral side in which the growth spiral opens more rapidly even through the chambers become elongate ovoid more slowly.

\section{Lilliputianella kuhryi (Longoria), 1974. Pl. 8, fig. 5.}

Hedbergella kuhryi Longoria, 1974, p. 60, pl. 14, figs. $1-3,4-6$.

?Clavihedbergella kuhryi (Longoria); Salaj, 1984, p. 594, pl. 3, fig. 13.

Remarks. L. kuhryi may be distinguished by its very broad shallow umbilicus, equal in diameter to as much as $\frac{1}{3}$ of that of the whole test, and by its subspherical chambers which become radially ovoid and pointed and laterally compressed in the latter half of the final whorl. The low aperture extends from the umbilicus fully to the periphery and possesses a narrow porticus; relict apertures and portici are visible in the chambers of the last half at least of the last whorl. Longoria (1974) believed $L$. kuhryi to be restricted to the upper part of the cabri zone. Salaj's specimens, which are doubtfully referable to this species, were obtained from Tunisian strata referred to the basal Bedoulian. Our specimens (Sample 8103) from Speeton are also Late Aptian, belonging to the upper part of the Leupoldina cabri zone.

\section{Lilliputianella maslakovae (Longoria), 1974.} Pl. 8, figs. 6, 7 .

Hedbergella maslakovae Longoria, 1974, p. 61, 63; pl. 20, figs. 1-3, 14-16; pl. 24, figs. 11-12 (Holotype), $13-14$.

?Hedbergella similis Longoria; Sigal, 1976, pl. 2, figs. $15,16$.

Hedbergella maslakovae Longoria; Caron, 1978, p. 658, pl. 2, figs. 1-2.

Remarks. L. maslakovae has slowly enlarging chambers (about seven in the last whorl) which become ovoid and higher than broad in the latter half of the last whorl. The trochospire is very low but the spiral side is flat (as depicted by Longoria (1974) for his holotype), not necessarily concave as in the original, type description. The umbilicus occupies about $1 / 5$ of the test diameter and the low aperture extends from the umbilicus to the periphery; because of the low trochospirality, the peripheral part of the penultimate aperture may be incompletely closed by the final chamber and may remain as a small sutural opening on the spiral side. Such sporadic openings in the spiral suture led Longoria $(1974$, p. $72-74)$ incorrectly to refer some species of Blefusciana (but not Lilliputianella) to Loeblichella Pessagno, which is a muricate, macroperforate, Late Cretaceous genus descended from Hedbergella. We consider these sporadic, relict openings in the spiral suture not to be valid as a generic criterion, in Lilliputianella or Blefuscuiana or even in Hedbergella.

Longoria $(1974$, p. 61) believed that the specimen figured by Kuhry (1971, as "Hedbergella sp. aff. Ticinella digitalis Sigal") belongs to L. maslakovae, but we believe it to be distinct because of its obliquely set and subquadrate later chambers.

Longoria $(1974$, p. 33$)$ recorded L. maslakovae to range within the Latest Aptian only (Upper Globigerinelloides algerianus zone to Lower Hedbergella trocoidea zone); the specimen figured by Sigal (1976) as "H. similis" was dated by him as Early Aptian. Our specimens (sample 8106) are believed to be referable to the Leupoldina cabri zone, earliest Late Aptian.

\section{Lilliputianella similis (Longoria), 1974.} Pl. 8, figs. 8, 9.

Hedbergella similis Longoria, 1974, p. 68-69; pl. 16, figs. $10-21(19-21=$ holotype $) ;$ pl. 18, figs. 12-13; pl. 23, figs. 14-16.

Hedbergella similis Longoria; Tronchetti, 1981, p. 141-242, pl. 37 , figs. $1-7$.

Remarks. L. similis differs from $L$. globulifera principally by the inflated chambers of the early whorls, as seen on the spiral side, and its slower opening of the growth spire. The holotype of $L$. similis (Longoria) has clavate, not pointed, ovoid chambers but the paratype (Longoria, 1974, pl. 23, figs. 14-16) has chambers which become pointed ovoid. Both morphologies are represented in our assemblage from the cabri zone of the Speeton section. The primary types were obtained by Longoria from the cabri zone of north Mexico and he (1974) believed the species to range from the gottisi zone (Early Aptian) to the lower part of the cabri zone (basal Late Aptian). Tronchetti (1981) recorded it as rare in the highest Bedoulian but commonest in the Early Gargasian, within the range of Globigerinelloides ferreolensis (i.e. upper cabri zone or younger Late Aptian in Longoria's biostratigraphy). 
Family Schackolnidae Pokorny

Genus Blowiella Kretzchmar and Gorbachik 1971, emended.

Type species. Planomalina blowi Bolli, 1959.

Emended diagnosis. Test planospiral, biumbilicate; chambers broader than or as broad as high, not radially and narrowly elongate; aperture interiomarginal, equatorial, symmetrical, extending laterally into each umbilicus; relict umbilical parts of early apertures remain open in the umbilici for most (usually half or more) of the last whorl; final aperture and relict apertures furnished with portici, usually broadest at their anterior and posterior margins; wall microperforate (external perforations less than two micrometers in diameter, separated by distances equal to two or more perforation diameters); wall smooth, not muricate.

Remarks. Blowiella differs from Schackoina and from Leupoldina in its lack of radially elongated chambers, from Globigerinelloides (Plate 9, figs. 7-9) and Biglobigerinella in its lack of muricae and macroperforations (which would be $5 \mu \mathrm{m}$ or more in diameter and separated by distances of one perforation diameter or less). Blowiella differs from Pseudohastigerina both in its microperforate, nonmuricate wall and in its retention of relict apertures, with their portici, in antepenultimate and earlier chambers.

Kretzschmar and Gorbachik (in Gorbachik, 1971) originally distinguished Blowiella from Globigerinelloides by the thinness of the wall in the former, believing that Blowiella lacked the layered, secondarily thickened walls and septal lamellae of Globigerinelloides. Apart from the impracticality of depending upon high quality thin sections of wall structure before one can attempt generic diagnoses, it is probably that all taxa of the Globigerinina develop lamellate walls during growth and that all possess bilamellar septa, even though the inner lamella may be extremely thin. In contast, the surface of the Blowiella test is distinctively different from that of other, similar Cretaceous planospiral genera and serves to define not only a group of closely related species but also a genus which appears to be restricted to the Early Cretaceous (Barremian to Aptian). We believe that Blowiella evolved directly from the similarly microperforate, nonmuricate but trochospiral Praehedbergella (compare Plate 2, figs. $8-13$ with $\mathrm{Pl}$. 4, figs. 5-8). The encroachment of the primary aperture onto the spiral side in trochospiral species approaching planospirality has long been known (e.g. "Loeblichella" moulladei Longoria, 1974; "L." convexa Longoria, 1974; etc.). Radial elongation of the later-formed chambers led to the evolution of Leupoldina in the Aptian-Albian. Because Blowiella lacked muricae it could never develop a peripheral muricocarinae (in contrast to evolution of Planomalina, Plate 4, figs. 8-9).

$$
\begin{aligned}
& \text { Blowiella blowi (Bolli), } 1959 . \\
& \text { Pl. 4, figs. 5-8. }
\end{aligned}
$$

Planomalina blowi Bolli, 1959, p. 260, pl. 20, fig. 2a-b (holotype), fig. 3 (paratype).

NOT Globigerinelloides blowi (Bolli); Kuhry, 1971, p. 228 , pl. 1, figs. $3 a-b$.

NOT Globigerinelloides blowi (Bolli); Longoria, 1974, p. 82 , pl. 4 , figs. $4,7,11-13$.

Globigerinelloides blowi (Bolli); Caron, 1978, p. 658, pl. 6, figs. 11, 12 .

Globigerinelloides blowi (Bolli); Butt, 1979, p. 258, pl. 3 , figs. 14-17.

Blowiella blowi or "prae-gottisi"; Sigal, 1979, pl. 2, fig. 20.

Globigerinelloides? blowi (Bolli); Tronchetti, 1981, p. 121, pl. 32, figs. 1-2.

\section{Explanation of Plate $\mathbf{8}$}

Lilliputianella and Blowiella.

Figs. 1-4. Lilliputianella globulifera (Kretchmar and Gorbachik), all from sample 8109, Leupoldina cabri zone, Speeton Cliff. $1, \times 190 ; 2, \times 170 ; 3$, axial view tilted showing height achieved by a septal aperture after removal of last chamber, $\times 190 ; 4$, surface of another specimen, $\times 1200$. (BMNH P52119-52122).

Fig. 5. Lilliputianella kuhryi (Longoria), both from sample 8106, upper Leupoldina cabri zone, Speeton Cliff, $\times 270$. (BMNH P52124).

Figs. 6-7. Lilliputianella maslakovae (Longoria), both from sample 8106, upper Leupoldina cabri zone, Speeton Cliff; both $\times 165$. (BMNH P52125-52126).

Figs. 8-9. Lilliputianella similis (Longoria), both from sample 8109 , Leupoldina cabri zone, Speeton Cliff; $8, \times 200$; 9a, $\times 190,9 b$, detail, $\times 4,700$. (BMNH P52118).

'Figs. 10-12. Blowiella duboisi (Chevalier), all from sample 8109, L. cabri zone, Speeton Cliff; 10, $\times 185 ; 11, \times 205$; $12 \mathrm{a}, \times 230,12 \mathrm{~b}$, detail of umbilicus and final porticus, $\times 500$. (BMNH P52150-52).

Figs. 13-15. Blowiella gottisi (Chevalier), all from sample 8109, L. cabri zone, Speeton Cliff; all $\times 175$. (BMNH P52153-55). 


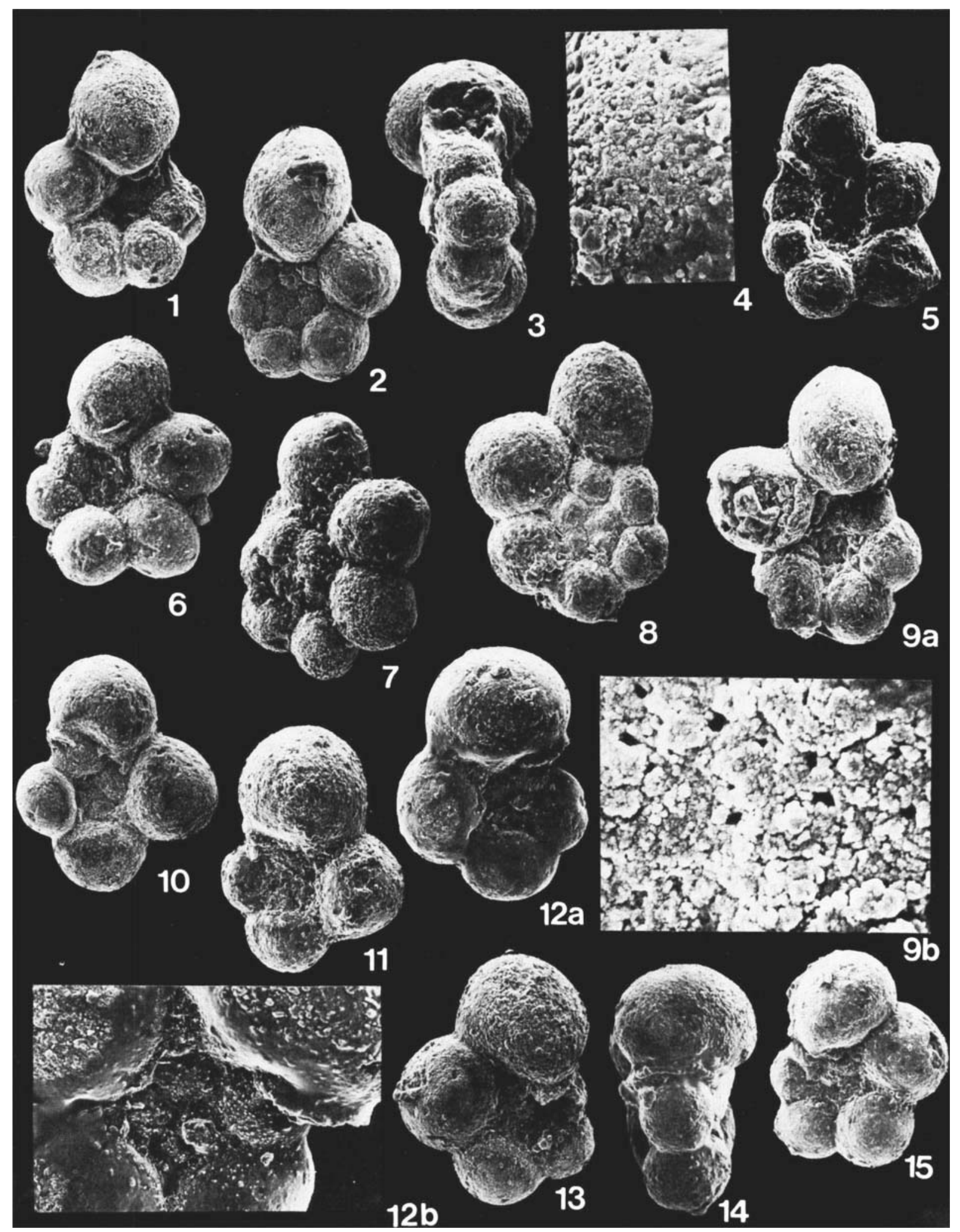


Remarks. $B$. blowi is distinguished by its subspherical chambers from the other species of Blowiella described here; this follows the original diagnosis given by Bolli (1959). The specimens figured by Kuhry (1971, from the Aptian Argos Formation) are different in that they possess a very small umbilicus, very high chambers and a very lobulate periphery.

Tronchetti (1981) recorded B. blowi from the Middle Bedoulian to Middle Gargasian, and noted that it disappeared a little below the first stratigraphical appearance of Globigerinelloides algerianus; Tronchetti (cit.) recognised that $B$. blowi, B. maridalensis (Bolli) and $B$. duboisi (Chevalier) formed a distinct group with smooth walls and "monolamellar structure", and he agreed with Moullade (1986) that the B. blowi group evolved into Blowiella gottisi (Chevalier) (and thence, through $G$. ferreolensis (Moullade), to $G$. algerianus Cushman and tenDam, by becoming more coarsely perforate, muricate, and "bilamellar"). The unity of the B. blowi group was such that Tronchetti (cit. p. 121) regarded $B$. maridalensis and $B$. duboisi as its full synonyms; we distinguish these species but recognise the genus Blowiella to be distinct from, and ancestral to Globigerinelloides.

Butt's (1979) record of B. blowi from D.S.D.P. site 397 (sample 42-2) is of disputed age, being referred by Butt to the Barremian (-Aptian?) but being dated as Late Hauterivian by Wind and Cepek (1979) on nannofloras. Bolli (1959) recorded the type specimens of $B$. blowi from the Leupoldina protuberans zone, Upper Cuche Formation, Trinidad, regarded as being Early Middle Aptian. Ali-Zade and Khalilov (1986) used $B$. blowi as a zonal index for the Early Aptian of Azerbaidzhan. Caron (1978) recorded B. blowi from the Late Aptian of D.S.D.P. site 364. The total range is therefore likely to be Barremian to Late Aptian.

Blowiella duboisi (Chevalier), 1961.

Pl. 8, figs. $10-12$.

Globigerinella duboisi Chevalier, 1961, p. 33, pl. 1, figs. 14-18.

cf. Globigerinelloides duboisi (Chevalier); Longoria, 1974 , p. 83-84, pl. 4, figs. $15-16$; pl. 11, figs. $12-13$.

Remarks. This species is characterised by its high chambers (as high as long) and by its exceptionally broad umbilicus (at least $25 \%$ of the greatest diameter). The chambers are higher than in any paratype of $B$. blowi and higher than in any specimen we would ascribe to that species.

B. duboisi was first described (Chevalier, 1961) from the Gargasian of the south of France. Longoria's specimens (1974) are doubtfully referable to $B$. duboisi because they possess a distinctly smaller umbilicus and their chambers enlarge more rapidly; Longoria (cit.) recorded this species from the Early Aptian (gottisi zone) to the lowest part of the Late Aptian (cabri zone), and his specimens may represent a form of the species which is stratigraphically and phylogenetically older than the typical form.

The specimens figured by Longoria (1974) are not well preserved, especially in the umbilical region. Our specimens distinctly possess imperforate areas on the inner umbilical shoulder of each chamber of the last whorl. Each imperforate area is a narrow band situated just above the porticus and is broadest in the mid part of the umbilical margin of each chamber. In areal distribution, the imperforate area is similar to (and consequently it may be analogous to) the umbilical part of the imperforate keel seen in rotaliporids. However. there is no extension of this imperforate area to the terminal face or the periphery of any chamber and there is no analogy to the development of any carina. As the test lacks muricae, there can, of course, be no muricocarinal development either umbilically or anywhere else. This wall modification does not seem ever to have been recorded before and we have observed it in only two other planospiral species (Blowiella gottisi and some specimens of $B$. saundersi).

\section{Blowiella gottisi (Chevalier), 1961.} Pl. 8, figs. 13-15.

Globigerinella gottisi Chevalier, 1961, p. 32-33, pl. 1, figs, 9a, b, (holotype) (?not pl. 1, figs. 10-13, paratypes).

Globigerinelloides gottisi (Chevalier); Longoria, 1974 , p. 85 , pl. 7 , figs. $10-13,(? 7-8)$.

Remarks. This species is distinguished from $B$. blowi primarily by its smaller umbilicus, and narrower, more restricted aperture. The umbilicus is smaller than in $B$. saundersi, which also possesses distinctly asymmetric chambers. Chevalier's (1961) paratypes have much higher chambers and more strongly depressed sutures than in the holotype and are probably distinct.

Chevalier (1961) obtained his primary types from the Gargasian and Longoria (1974) has confirmed its occurrence in the ferreolensis zone of the Gargasian stratotype. Longoria (cit.) also recorded this species from the cabri zone of Mexico; our specimens were obtained from this zone at Speeton.

\section{Blowiella maridalensis (Bolli), 1959. PI. 9, figs. 1-3.}

Planomalina maridalensis Bolli, 1959, p. 261, pl. 20 , figs. 4, 5 (paratypes), 6 (holotype).

Globigerinelloides maridalensis (Bolli); Longoria, 1974, p. 86, pl. 9, figs. 4, 7, 10-13.

Globigerinelloides blowi (Bolli); Longoria, 1974, p. 82, pl. 4, figs. 4, 7, 11-13. 
Globigerinelloides blowi (Bolli); Masters, 1977, p. 406-408, pl. 11, fig. 3 (topotype of Planomalina maridalensis Bolli).

Remarks. We follow Bolli (1959) in distinguishing this species by its consistently depressed, reniform chambers, which are distinctly longer than they are high. Like $B$. blowi, it possesses a broad umbilicus, but the two species seem consistently to be separable on their chamber shapes. Bolli (1959) recorded the existence of specimens with four or five chambers in the final whorl and both are represented in our collections; that figured here on plate 9 , figure 2 is close to the holotype, while that shown on plate 9 , figure 1 is similar to the five-chambered, figured paratype.

Longoria (1974) illustrated this species from the cabri zone of La Drôme, France and La Peña, Mexico, and also from the ferreolensis zone of the stratotype Gargasian; he recorded the range of "Globigerinelloides" maridalensis to be from its nominate zone in the Late Early Aptian. The primary types were obtained from the Maridale Formation, which was considered by Bolli (1959) to span the Latest Aptian to Early Albian interval.

It appears to be a characteristic of well preserved specimens of $B$. maridalensis (and $B$. saundersi) that the interior part of the porticus over the equatorial part of the aperture) is developed as a broad projecting flange ( $\mathrm{Pl} .9$, figs. 2, 3). this is seen also in one of the specimens (Longoria 1974, pl. 9, fig. 7) illustrated from the Gargasian stratotype. Forwardly projecting, shelflike portici of this form are rare in Globigerinelloides or Biglobigerinella but are characteristic of species of Leupoldina and Schackoina. This reinforces the hypothesis that Blowiella belongs to the Schackoinidae.

\section{Blowiella saundersi (Bolli), 1959. Pl. 9, figs. 4-6.}

Planomalina saundersi Bolli, 1959, p. 262, pl. 20, figs. 9, 11 (paratypes), 10 (holotype).

Globigerinelloides saundersi (Bolli); Masters, 1977, p. 412-413, pl. 11, figs. 6 (topotype).

NOT Globigerinelloides saundersi (Bolli); Langoria, 1974 , p. 88, pl. 3, figs. 2, 6-12; pl. 9, figs. 8, 9.

Remarks. This species is characterised by its asymmetrically ovoid chambers, which are distinctly higher in their posterior part than anteriorly. Occasionally, the chambers become as high as long (Pl. 9, fig. 6) but they still retain their characteristically asymmetric shape. The topotype from the Maridale Formation of Trinidad, figured by Masters (1977), has exceptionally elongate chambers which even approach gross homeomorphy with the macroperforate, muricate Eohastigerinella watersi (Cushman) of the Late Cretaceous. Such extreme radial elongation is rare in populations of $B$. saundersi and not yet been disting- uished taxonomically; it does, however, exemplify the phenomenon of iterative homeomorphy in the evolution of the Globigerinina (in this case, a member of the Schackoinidae approaching the morphology of a member of the Eohastigerinellinae).

This tendency (radially to elongate later chambers) is a clear indication of the affinity between Blowiella and Leupoldina, reinforcing the similarity in morphology exemplified by the biumbilicate, four-to-five chambered planospires, smooth microperforate walls and forwardly-projecting portici of each genus. The resemblance between juvenile Leupoldina and adult $B$. saundersi is so great that they have even been confused: for example, specimens called "Globigerinelloides" saundersi by Longoria (1974, pl. 3, figs. 2, 6-9), from the Leupoldina cabri zone, have radially elongate, pointed chambers but are juvenile specimens of $L$. pustulans (Bolli) which occurs in the same samples.

The primary types of Blowiella saundersi were obtained from the barri zone of the Maridale Formation, Trinidad, which is believed to be latest Aptian to Early Albian in age. Our specimens came from the cabri zone, early Late Aptian.

Rare specimens (Plate 9, figure 5) appear to possess imperforate zones on the innermost umbilical margins just above the apertural portici. These imperforate areas do not extend to the terminal face or the periphery and are not present in all specimens (compare $B$. duboisi and $B$. gottisi).

\section{Genus Leupoldina Bolli, 1957 emended.}

Type species: Leupoldina protuberans Bolli, $1957=$ Schackoina cabri Sigal, 1952.

Emended diagnosis. Test planospiral, with four to six chambers per whorl, laterally compressed, with later chambers becoming radially and broadly elongate, digitate or bulbiform or both; umbilici evolute to partially involute; aperture equatorial, interiomarginal, a low arch (which may become symmetrically bipartite), furnished with a porticus which is broadest anteriorly. Wall microperforate, smooth or weakly granular, not muricate. The radial extensions of the chambers normally do not appear until the second whorl, and in that whorl they may develop, one or two or three from each chamber; the number of extensions per chamber may increase in ontogeny (or may never exceed one per chamber).

Additional description. The test of Leupoldina is essentially planospiral and bilaterally symmetrical throughout ontogeny. Where multiple chamber extensions occur they are developed essentially symmetrically about the equatorial plane. Multiple chamber extensions (as in adult $L$. cabri) leads to lateral broadening of the chambers and increasing involution of the umbilici; where chamber extensions remain 
single, the umbilici may be almost wholly evolute. Remarks. Leupoldina differs essentially from Schackoina in

1. the chamber extensions gradually tapering from, and not suddenly narrowing from, the chamber of origin.

2. the umbilici being evolute, at least in early ontogeny and where chamber extensions remain single, and

3 . in the occasional development, at the ends of the radial chamber extensions, of bulbous terminations.

4. In thin section, Schackoina differs not only by the narrowness of its tubulospines, but also by their appearance even within the first whorl of chambers (see Masella, 1960, and Ayala-Castañares, 1962, pl. 7, fig. 3a; pl. 11, fig. 3a), whereas, in Leupoldina, radial extensions do not occur until after the first whorl.

Bolli (1957, p. 275) distinguished Leupoldina from Hastigerinoides Brönnimann in its possession of "two or more symmetrically arranged bulb-shaped chamber extensions in some or all of the chambers of the last whorl". These bulb shaped terminations are very rarely preserved, and cannot always be proven even to have been present; they are not a practical means of distinguishing the genus. Secondly, some species which, in their morphology and geological age, are clearly congeneric with Leupoldina cabri, develop no more than one radial extension on each chamber (e.g. "Schackoina" pustulans Bolli, 1957). Longoria (1974) has already modified the diagnosis of Leupoldina by admitting species with chambers having "one or two" bulb-shaped extensions. Hastigerinella digituta (Rhumbler) (= Hastigerinopsis digitiformis Saito and Thompson), a modern relative of the phylogenetically quite distinct genus Hastigerina Thomson, can also develop one or two or three clavate to terminally bulbiform radial extensions in its later chambers; the number of such extensions is of no generic significance.

The essential emendation we have made to the diagnosis of Leupoldina is to emphasise the significance of its microperforate nonmuricate wall. This im- mediately distinguishes it from the phyletically independent and stratigraphically later genera, with macroperforate walls, such as the muricate Eohastigerinella Morozova and Hastigerinoides Brönnimann, and the spinose Hastigerinella Cushman and Bolliella Banner and Blow. The low interiomarginal aperture of Leupoldina is distinct from the high elongate aperture of the Eocene Clavigerinella Bolli, Loeblich and Tappan, which is also, of course, macroperforate.

The microperforate wall of Schackoina and Leupoldina is recognisable in thin section (e.g. Ayala Castanares, 1962, pl. 11, fig. 3b, for Schackoina cenomana, compare pl. 13, fig. 1a, for the macroperforate Clavihedbergella simplex). Gorbachik (1986, pl. 28, fig. $3 \mathrm{~b})$ shows $L$. protuberans $(=L$. cabri) to possess microperforations of about $0.5 \mu \mathrm{m}$ external diameter; in contrast, Eohastigerinella watersi has external perforation diameters of $3 \mu \mathrm{m}$ or more, as shown by Masters (1977, pl. 13, figs. 2 and 3).

The planospiral coiling and the microperforate, non-muricate wall of Leupoldina immediately indicate its affinity to Blowiella, on the one hand, and to Schackoina on the other. Species of Blowiella are known from horizons at least as old as Barremian ( $B$. blowi in Butt, 1979) and are not known to occur above the Latest Aptian or Early Albian. Leupoldina ranges from the Late Barremian (Sigal, 1952; Salaj, 1984) and Early Aptian (Salaj, 1984) into the Albian, and rare occurrences (unconfirmed) may be a young as Cenomanian (Gorbachik, 1986). Schackoina is not known below the Late Albian-Early Cenomanian (e.g. $S$. primitiva Tappan, 1940, Grayson Formation), becoming abundant and diverse in the Cenomanian (e.g. Reichel, 1948; Masella, 1960) and persisting at least as high as the Campanian (S. cushmani Barr, 1962) and even to the Maastrichtian (Bolli, 1959). This stratigraphic sequence conforms to a punctuated morphological series in which the ancestral Blowiella spp., with its reniform or subglobular chambers, can give rise in the Middle Aptian to the radially elongate Leupoldina, with the tubulospinose and more involute Schackoina

\section{Explanation of Plate 9 \\ Blowiella and Globigerinelloides.}

Figs. 1-3. Blowiella maridalensis (Bolli), samples 8108/8109, L. cabri zone, Speeton Cliff; fig. 1 (8108), 1a, $\times 175$, $1 \mathrm{~b}$, detail $\times 2,020$; figs. 2 and $3(8109), 2, \times 245 ; 3, \times 180$. (BMNH P52142-44).

Figs. 4-6. Blowiella saundersi (Bolli), sample 8106, upper L. cabri zone, Speeton Cliff; $4, \times 200 ; 5, \times 190 ; 6 a, \times 195$, $6 \mathrm{~b}$, detail of microperforations $\times 4,050$. (BMNH P52145-47).

Figs. 7-8. Primitive Globigerinelloides cf. ferreolensis (Moullade), sample 8106, upper L. cabri zone, Speeton Cliff; $7, \times 170 ; 8 \mathrm{a}, 8 \mathrm{~b}, \times 200 ; 8 \mathrm{c}$, enlargement of wall showing microperforations $\times 2,500$. (BMNH P52137).

Fig. 9. Globigerinelloides ferreolensis (Moullade), $\times 192$ (from Tronchetti, 1981, pl. 32, fig. 7, enlarged to same scale as figs. 7-8), Gargasian, La Bedoule-les Fourniers, S.E. France. 


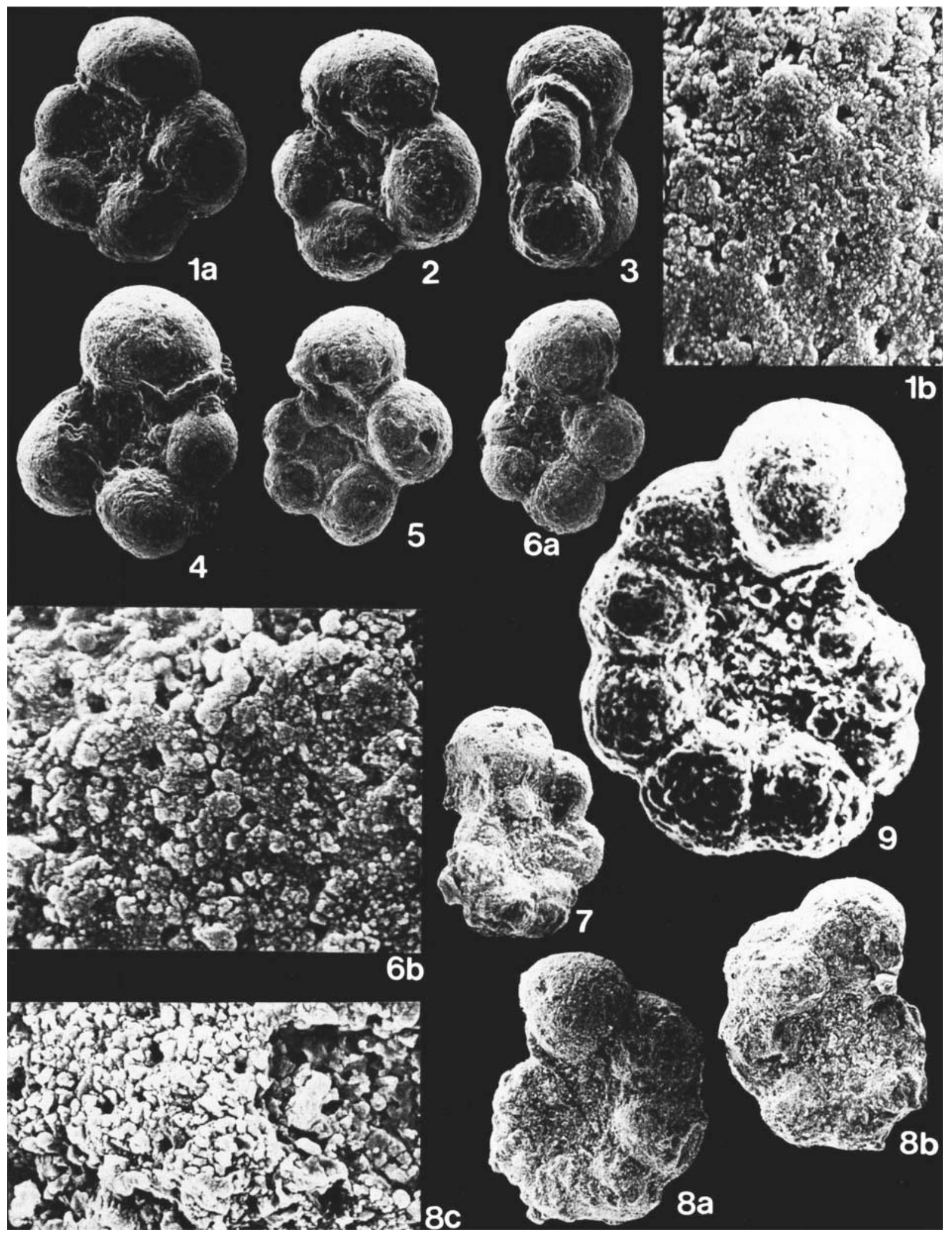


appearing in the Latest Albian or Earliest Cenomanian. The anteriorly projecting shelf-like porticus, so characteristic of both Schackoina and Leupoldina, is first seen in Blowiella (e.g. B. maridalensis, Pl. 9, figs. 2,3 ) and late-ontogeny high chambers, distally subconical, can occur in $B$. saundersi (Pl. 9, fig. 6). The suggestion that Leupoldina pustulans evolved from $B$. saundersi has already been made by Longoria (1974) but the specimens which he figured as $B$. saundersi (1974, p. 88, pl. 3, figs. 2, 6-12; pl. 9, figs. 8-9) are in fact juvenile Leupoldina. Gorbachik (1986) has suggested that Schackoina evolved from "Clavihedbergella" (recte Lilliputianella) bizonae (Chevalier) in the Late Albian, but no morphological intermediates are known. A direct phyletic relationship between Leupoldina and Schackoina is more probable.

Leupoldina gr. cabri (Sigal), 1952.

Pl. 10, figs. 1-8.

Schackoina cabri Sigal, 1952, p. 20-21, figs. 18.

Schackoina pustulans pustulans Bolli, 1957, p. 274, pl. 1, figs. 1-7.

Schackoina pustulans Bolli quinquecamerata Bolli, 1957, p. 275, pl. 1, figs. 1-7.

Schackoina reicheli, Bolli, 1957, p. 275, pl. 1, figs. 8-10.

Leupoldina protuberans Bolli, 1957, p. 277, pl. 2, figs. $1-13$.

Schackoina reicheli Bolli; Sigal, 1959, p. 74, figs. 48-49.

Leupoldina reicheli (Bolli); Gorbachik, 1971, p. 138, pl. 30 , figs. $8 \mathrm{a}, \mathrm{b}$.

Leupoldina reicheli (Bolli); Longoria, 1974, p. 92, pl. 27, fig. 17.

Leupoldina pentagonalis (Reichel); Masters, 1977, p. 425-426, pl. 14, figs. 2, 3.

Schackoina gr. cabri Sigal; Tronchetti, 1981, p. 130 -131 , pl. 33, fig. 7-9.

Leupoldina pustulans (Bolli); Salaj, 1984, p. 856-857, pl. 3, fig. 10.
Discussion. It does not seem possible realistically to distinguish between the taxa which are listed above in synonymy for this group. There appear to be all intermediates between those adult specimens with four chambers in a whorl and those with five. Broad chamber extensions develop ontogenetically at the fifth or later chamber following the proloculus (compare the appearance of narrowly constricted tubulospines as early as the second chamber after the proloculus in Schackoina cenomana - see e.g. Masella, 1960). The elongations are in thickness about $\frac{1}{3}$ of the chamber length (compare Schackoina, where the tubulospines are $1 / 4$ to $1 / 5$ as thick as the chamber is long). The last-formed or penultimate chambers may have double, bifurcating elongations (pl. 10, figs. 7,8 ); in such specimens, the earlier part of the tests seem identical to other tests which carry single elongations on each chamber. We can see no reason to consider these forms to be different species, and they could not in practice be distinguished if the last-formed chamber were missing.

Masters (1974) distinguished L. cabri (= L. protuberans) from $L$. pentagonalis (Reichel) by its supposedly tighter coiling and shorter chambers. In our assemblange we seem to have representatives of both forms with integradation between them, although the assemblage as a whole contains more forms closer to $L$. pentagonalis (as understood by Masters) than to $L$. cabri. Masters (cit.) considered $L$. pentagonalis (Reichel) to be a senior synonym of $L$. pustulans, $L$. reicheli and $S$. gandolfii Reichel; the last is a true Schackoina of Cenomanian age and cannot be a synonym, and the primary types of $S$. pentagonalis are so ill-preserved that their generic identity is uncertain. Consequently, only $L$. reicheli (Bolli) need be considered here. $L$. reicheli and $L$. cabri are both evolute; Sigal's syntype of the latter (from the Aptian of Tunisia; Sigal, 1952, p. 21) shows blunt and bulbous elongations that rapidly double on each chamber, while the primary types of $L$. reicheli (Bolli, 1957, pl. 1, figs. 8-10) have single, long chamber extensions. Our specimens have long extensions, like $L$. reicheli, which

\section{Explanation of Plate 10}

Figs. 1-8. Leupoldina gr. cabri (Sigal), variation within one sample, 8109 , L. cabri zone, Speeton Cliff. Figures 1 and 2, "juveniles" with Blowiella-like early whorls and a forwardly projecting porticus (compare plate 8 , figures 10, 12a; plate 9, figures $4-5$.) $1, \times 410 ; 2, \times 340$. Figs. 3a, 3b, specimen with Blowiella-like early whorls and radial extensions of variable breadth; $3 a, \times 214,3 b$, enlargement of early whorls, $\times 475$. Figs. $4-8$, variable "adult" morphology within the single assemblage: figs. 4-6, variation from 4 to 5 chambers per whorl and in the degree of umbilical involution; 4,$376 ; 5, \times 207 ; 6, \times 188$; figs. 7-8, specimens with sporadic bifurcation of chamber extension; 7, $\times 293 ; 8, \times 210$. (BMNH P52132-36).

Fig. 9. Blefuscuiana crassa (Bolli), Late Coniacian ("Hedbergella crassa (Bolli)") after Caron, 1978); 9a, 9b, both $\times 200$.

Fig. 10. Blefuscuiana archeocompressa (Blow), Early Danian ("Globorotalia (Turborotalia) cf. archeocompressa" Blow); 10a (after Blow, 1979, pl. 64), $\times 365$; $10 \mathrm{~b}$ (after Blow, 1979, pl. 58), $\times 400$. 


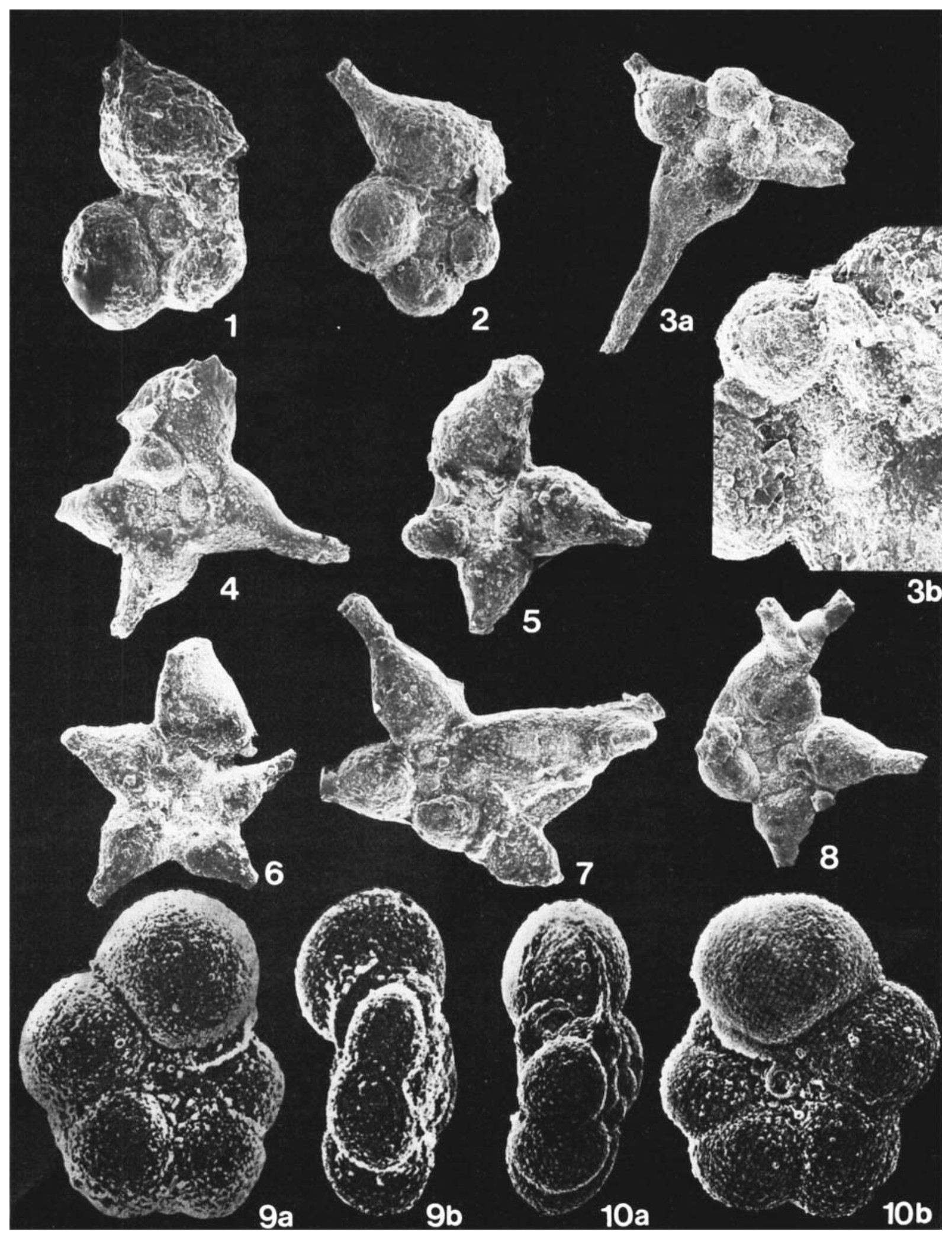


can double, like $L$. cabri. Our specimens very closely match those figured by Gorbachik (1986) as both $L$. pustulans (Bolli) and L. reicheli (Bolli) from the Middle Aptian of the Crimea. Also, our specimens, like those figured by Tronchetti (1981), only rarely carry bifurcating elongations. The development of slender or bulbous elongations, and their singularity or their plurality, seems to vary between and within individuals and neither character seems to correlate with with chamber number or umbilical breadth.

The nature of "Hastigerinoides" cepedai Obregon, 1959 (cabri zone, Mexico) can only be determined after re-examination of the type specimens. The only illustrated specimen (Obregon, 1959, pl. 4, fig. 5, which is not necessarily the holotype) shows an evolute test in which the last formed chambers become narrowly elongate as in Leupoldina; however, the wall was said by Obregon $(1959$, p. 151) to be finely hispid, which is not a character of Leupoldina or Schackoina.

Stratigraphic distribution. We have obtained our specimens from the Speeton section from a horizon independently assessed on nannofloras by J. A. Crux as late Early to Late Aptian. The planktonic foraminifera are consistent with its reference to the $L$. cabri zone, considered by Longoria (1974) to be earliest Late Aptian in age. Bolli's primary types of L. reicheli (Bolli, 1957) were obtained from Trinidad outcrops of probable Aptian age, and Sigal (1959) illustrated $L$. reicheli, very similar to our specimens, from the Gargasian of the Vocontian Trough, Hautes Alpes. Longoria (1974) identified $L$. reicheli in the La Peña Formation, northern Mexico, which has yielded ammonites of Early Aptian to Early Albian ages; he considered the range of $L$. reicheli to be within the early part of the Late Aptian. Bartenstein and Bolli (1986) also considered $L$. reicheli to be a Late Aptian species. Gorbachik (1986, p. 148) drew the northernmost limit of Aptian Schackoinidae as passing through northern England and our record from Speeton fits this hypothesis.

\section{DISCUSSION}

Phylogeny. In the previous section we have described elements of the phylogeny of the microperforate Jurassic/E. Cretaceous Globigerinina, and this is integrated and shown schematically on Figure 1. In summary, the Favusellacea (probably aragonitic) is considered to contain, in the Jurassic, two genera, each being muricate. Globuligerina, characterised by its bulimine-like aperture, appears in the Bathonian (possibly Late Bajocian) and persists to the Oxfordian (possibly Early Kimmeridgian) but leaves no descendants. In contrast, Conoglobigerina, with its low intraumbilical aperture, has a virtually continuous stratigraphic record from the Bajocian to the Valanginian; it may, uniquely, exhibit dimorphism. The lateral fusion of adjacent muricae, to form irregular ridges on the test surface, occurs sporadically in Late Jurassic Globuligerina as well as in Conoglobigerina, but only in the latter do these ridges fuse to isolate small areas of microperforations. Continuous reticulation of the test surface, with complete isolation of microperforation groups, appears in the Hauterivian and defines the genus Favusella, which persists to the Early Cenomanian. The evolution from Conoglobigerina gulekhensis (Valanginian-Berriasian) to $F$. washitensis appears to be a morphologically continuous, gradational series, with no punctuation. The post-Hauterivian dispersal of Favusellaceans from low western latitudes to a circumglobal distribution, low to high latitudes, is well known (Gorbachik and Kuznetsova, 1983) and illustrates their success as members of the holoplankton. In the Aptian, migration of the aperture to an intra-extraumbilical position, produced the Aptian-Albian Ascoliella, the only "globorotalid" morphology ever achieved in the Favusellacea.

If Conoglobigerina lost its muricae to produce a smooth wall surface, the morphology of the genus Gorbachikella would be produced. No intermediate forms are known with certainty, but the loss could have been gradual: the Callovian species meganomica appears to have muricae conspicuously only on the early whorls of its spiral side (Gorbachik, 1986, pl. 5, fig. 2a; Kuznetsova and Gorbachik, 1986, pl. 16, fig. $8 \mathrm{a}, 8 \mathrm{~b})$ and this may be the ancestral form. Migration of the aperture to an intra-extraumbilical position, retaining an essentially quadriserial test, would have produced Praehedbergella from Gorbachikella in the Hauterivian. Similar tests, four or five chambers in the last whorl, but now planospiral and with the aperture extending into both umbilici, evolved Blowiella in the Barremian. Early Leupoldina differs from Blowiella only in the radial elongation of its clavate chambers. The origin of Schackoina is not clear, because a stratigraphical gap may occur between the youngest Leupoldina and oldest true Schackoina, but the latter appears to be distinguishable only by the abrupt narrowness of its chamber elongations (tubulospines).

Increase in the number of chambers in each whorl, in Praehedbergella descendants, evolved the Hedbergellalike but microperforate Blefuscuiana. This genus gave rise uniquely to the streptospiral Wondersella in the Latest Aptian, but by radial elongation of its chambers it could have produced species of Lilliputianella more than once during Aptian time. This last genus homeomorphs Clavihedbergella, from which it is separated by virtually all of Albian time and from which it is phyletically distinct (the latter genus being descended from Hedbergella directly).

The genus Hedbergella (and the Hedbergellidae) seem to have arisen directly from Blefuscuiana in the later part of the Early Aptian (e.g., H. excelsa 


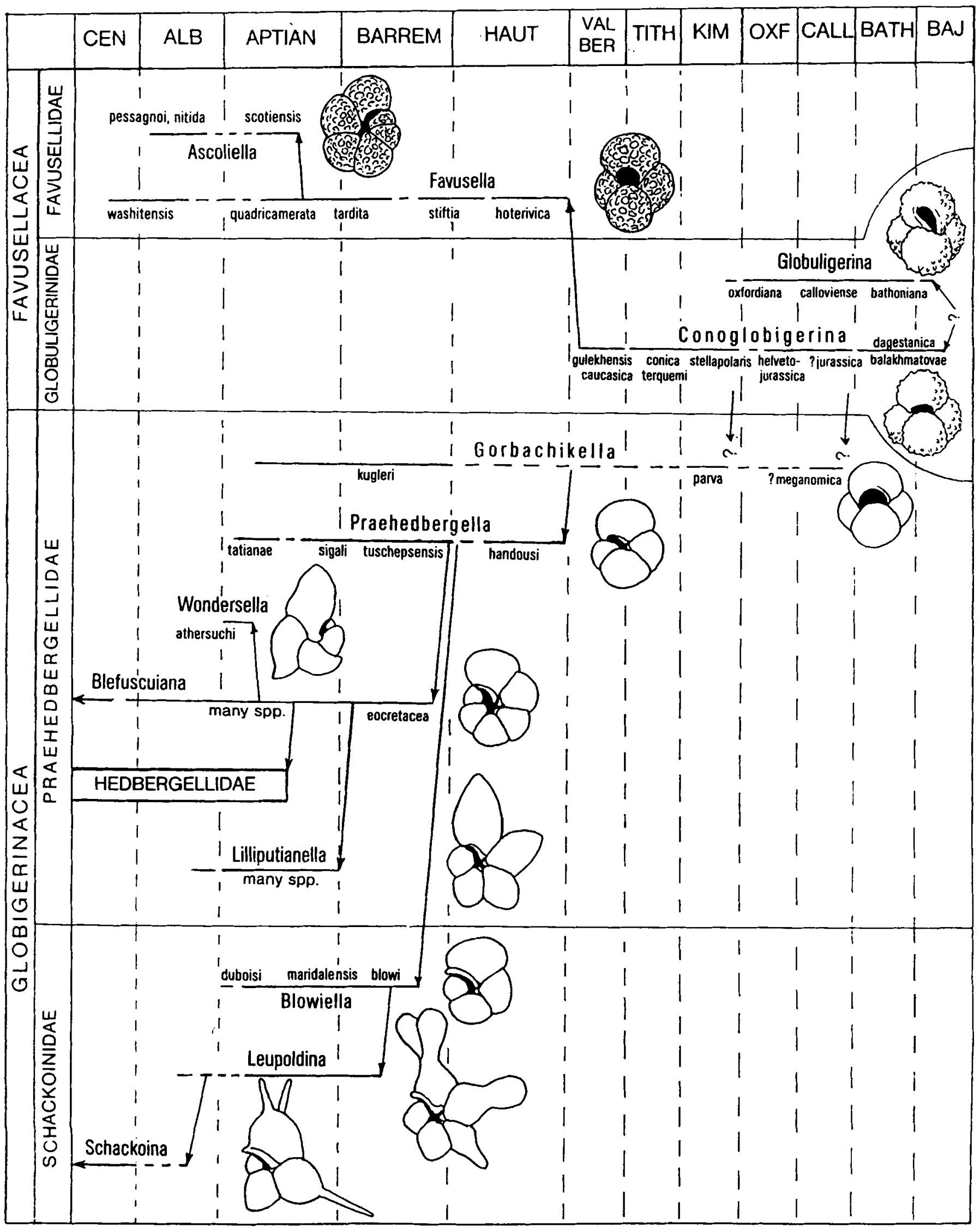

Fig. 1. Suggested phylogeny and the phyletic classification of the microperforate Middle Jurassic to Early Cretaceous Globigerinina. 
Longoria, blowi zone), and through $H$. praetrocoidea Kretchmar and Gorbachik (in Gorbachik, 1986, p 95, pl. 16, cabri zone, Early Late Aptian) to $H$. trocoidea (Gandolfi) (Late Aptian, algerianus zone, to basal Albian, teste Caron, 1985).

The macroperforations which characterise the Hedbergellidae soon were accompanied with the development of muricae, from which muricocarinae were later to develop (never seen in the Praehedbergellidae). In the Latest Aptian (Ticinella bejaouensis Sigal), the first Rotaliporidae appeared, their macroperforate and muricate tests reflecting their ancestry in Hedbergella trocoidea, but also developing accessory umbilical apertures which are (also) never yet seen in the Praehedbergellidae (Sigal, 1966A).

The origin of the genus Globigerinelloides tenDam also appears to have been in species of Blefuscuiana. Some of these species (e.g., $B$. globigerinelloides lobulata, Plate 6, figures 1-3) became pseudoplanospiral in the final whorl, with the aperture encroaching onto the evolute, spiral side. Such species are many chambered (often with six or more chambers in the last whorl) as are the earliest species of Globigerinelloides.

The oldest known species of Globigerinelloides is $G$. ferreolensis (Moullade) with a range believed to be within the Late Aptian. It is a macroperforate species with weak muricae developed over the earlier chambers of the last whorl (Caron, 1985, fig. 29, 13a-b; Plate 9, figure 9 after Tronchetti, 1981). On these criteria, typical $G$. ferreolensis is clearly fully congeneric with $G$. algeriana Cushman and tenDam (e.g., as well figured in Ruggieri, 1963). Moullade (1961) observed that specimens of $G$. ferreolensis in the base of the Gargasian had seven chambers per whorl while those from the Upper Gargasian had eight. This is confirmed by Longoria (1974, p. 85), who recorded that specimens with only seven chambers in the last whorl first appeared in the upper part of the Leupoldina cabri zone. Our specimens from the $L$. cabri zone (pl. 9, figs. 7-8) are planospiral, with seven chambers in the last whorl and weak muricae in the early part of that whorl, but are microperforate. They are smaller in size but are otherwise very similar to true, macroperforate $G$. ferreolensis (Plate 9, compare figures 8 and 9). The primitive " $G$." cf. ferreolensis from the $L$. cabri zone of Speeton is an almost perfect morphological intermediate between pseudoplanospiral Blefuscuiana and true Globigerinelloides. The evolution must have been quite rapid because macroperforate $G$. ferreolensis with eight chambers in the last whorl is known from the upper part of the L. cabri zone of Mexico (Longoria 1974, pl. 5 , figs. 7-8). By the succeeding $G$. algerianus zone of the Late Aptian, G. ferreolensis typically has 8 to 9 chambers in the last whorl) and is often larger (see Moullade, 1961; Tronchetti, 1981; Caron, 1985). Its immediate descendant, $G$. algerianus Cushman and
tenDam, has appeared, with 10-12 chambers in the last whorl, a broader umbilicus and, sometimes, lateral compression of the later chambers (e.g. Longoria, 1974, pl. 6, fig. 18; Gorbachik, 1964). As described by Sigal (1966, p. 16-26), G. algerianus evolved into "Planomalina" cheniourensis Sigal near the top of its zone, with the development of a partial muricocarina and a further increase in chamber number (11-13 in the last whorl). $P$. cheniourensis and $G$. ferreolensis both became extinct at the close of the Aptian time (Caron, 1985).

From the above it appears that planospirality and the acquisition of muricae occurred before the development of macroperforations in the evolution of Globigerinelloides, and that the early development of muricae heralded the later evolutionary appearance of a peripheral muricocarina. The sequence appears to have been quite different in the evolution of the Early Cenomanian taxon Planomalina buxtorfi (Gandolfi) (Plate 4, figure 10) from its ancestor, the Late Albian P. praebuxtorfi (Wonders, 1975, 1980; Plate 4, figure 9), which itself evolved from the Albian "Globigerinelloides" caseyi (Bolli et al.) (Wonders, 1975), a macroperforate but nonmuricate species (see Hart $\boldsymbol{e t}$ al., 1981, p. 198, as "G. bentonensis (Morrow)", pl. 7.13, figs. 7-9). "G." caseyi must have evolved from an equally nonmuricate, trochospiral form in the Earliest Albian. A possible contender is the species called "Hedbergella sp. 17" by Magniez and Sigal (1984, pl. 6, figs. 6-11) from the "lower to basal Middle Albian" of the Celtic Sea (D.S.D.P. Site 459, Cores 39-44). This (as yet unnamed) taxon has 7-8 chambers in a final whorl which trends to planospirality, with the spiral side becoming partially involute and the aperture encroaching over the periphery; it is macroperforate but has few or no muricae.

Therefore, it appears that Blefuscuiana gave rise to a Globigerinelloides and through this to "Planomalina" cheniourensis wholly within Late Aptian time; this evolution seems to have been accompanied by increasing geographic restriction, because "P." cheniourensis is still unknown outside the Late Aptian of North Africa, over a quarter of a century since that species was first described. On the other hand, the Planomalinidae derived from Hedbergella in the Late Albian to Early Cenomanian interval, and its most advanced member, $P$. buxtorfi, is known circumglobally. In summary, the Globigerinelloididae and the Planomalinidae had different origins and different phyletic histories; they exemplify parallel evolutionary trends, each made possible by the development of planospirality and muricae (in different sequences) but they are not directly related. Biglobigerinella Lalicker (type species B. multispina Lalicker, 1948, a junior synonym of Globigerinella abberanta Netskaya, 1948, according to Masters, 1977 , p. 401 ) is a Late Cretaceous genus 
derived from Late Cretaceous species of Hedbergella and is phyletically separate from both the lineages discussed above (Globigerinelloides sensu AbdelKireem (1980) is really Biglobigerinella).

Functional evolution. Caron and Homewood (1983) have suggested that during the Middle and Late Jurassic "Protoglobigerina" (i.e. Conoglobigerina and Globuligerina) inhabited the shallow waters of the continental shelf, and that primitive globigerines did not colonise the open ocean until the HauterivianBarremian. Banner (1982) and Caron (1983) suggested that the Jurassic taxa, in part at least, were meroplanktonic, with a benthic juvenile stage (as suggested by the multicamerate early whorls), becoming planktonic in the adult prior to reproduction and dispersal of gametes in the shelf surface waters. This is a reproductive cycle which would parallel that of the "Tretomphaloid" discorbids and Cymbaloporids, shelf foraminifera which have evolved a planktonic reproductive phase within the last $10 \mathrm{my}$ (Banner et al., 1985). There is now evidence for sexual dimorphism in some species at least of the Jurassic Globuligerinidae, which would support the hypothesis of the existence of reproductive cycles similar to those of some essentially benthonic smaller foraminifera. These ideas would explain the relatively restricted geographic limits of the Globigerinina during Jurassic time (as mapped by Gorbachik, 1986, p. 143 . 144) compared to their wide distribution in and after the Early Cretaceous.

Caron and Homewood (1983) also suggested that, while the open sea surface was colonised by "primitive" species during the Hauterivian-Aptian, more evolved, carinate species of Albian and younger times migrated into deeper oceanic waters. Hart and Ball (1986) have related the evolutionary appearance of Late Albian carinate genera (Praeglobotruncana, rotaliporids) to the termination of Early Cretaceous oceanic anoxicity; they suggest that anoxic subsurface waters had previously prevented deep water colonisation by planktonic foraminifera. We suggest that the microperforate tests of Jurassic and Cretaceous planktonic foraminifera were adequate to allow gas and cation exchange between intrathalamous cytoplasm and seawater in the well oxygenated surfaces of shelf seas and oceans, but the increased test porosity which macroperforate evolution would produce was necessary in order to maintain efficient gas/cation exchange in less well oxygenated (an otherwise biogeochemically different) subsurface waters. Also in the thermohaline stratification of the Mesozoic ocean, vertical thermal gradients, although weak, must have been created near surface by solar heating and its turbulent diffusion to a relatively shallow Ekman depth; colonisation of sub-surface cooler waters is likely to be enhanced by increased test porosity, as it is today in upper-water species from warm to cool latitudes (Frerichs et al., 1972). Therefore, the macroperforate Hedbergellidae and their descendants are likely to have been more capable of populating deeper, cooler and less oxygenated oceanic waters than were their microperforate ancestors. The absence of macroperforate Hedbergellidae from the Late Aptian samples of Speeton (compare the La Drôme assemblages described by Longoria, 1974) may be due as much to the relative shallowness of Speeton Late Aptian sedimentation as to its more northern latitude, just as the porosity of Cenomanian Hedbergel$l a$ and Rotalipora in Wyoming is less than in Texas (Frerichs and Ely, 1978).

The muricae of the Favusellacea and the Globigerinacea are morphologically indistinguishable but seem to be independent evolutionary developments. All the Favusellacea are essentially muricate, from Bajocian to Cenomanian, and the muricae or the ridges derived from them are distributed almost uniformly over each chamber surface. In the Globigerinellacea, muricae appeared with the Hedbergellidae and the Globigerinelloididae only from middle Aptian times; then and thereafter the muricae are concentrated in the approaches to the apertures and on the test periphery. There is such a phylogenetic gap between these two developments that the muricae of each superfamily cannot be homologous and may not even have been analogous in function.

In some benthic foraminifera, "tubercles" (which look the same as "muricae") are also concentrated on the test surface at the approaches to apertures and the umbilicus. Here, their function seems to be the disaggregation of rasping of food particles prior to their ingestion through the apertures (Alexander and Banner, 1984) or digestion in the umbilicial cytoplasmic "reservoir" (Alexander, 1985 MS). Is it not possible that the muricae of the apertural areas of Globigerinacea, being similar in size, shape, density and distribution, had a similar function? In some benthic Rotaliina (Haynesina, Rosalina) partial closure by skeletal material of the umbilical digestive cytoplasm (Alexander, 1985 MS) seems to be advantageous for extrathalamous digestion of disaggregated particles. Advanced Hedbergellidae evolved analogous structures partially to enclose their umbilici (e.g. Ticinella, Rotalipora); this could be a similar partial enclosure of an umbilical digestive "reservoir" of cytoplasm for similarly disaggregated particles. Even predatory, carnivorous living globigerinids partially digest disaggregated prey in extrathalamous digestion vacuoles (Spindler et al., 1984). It is significant that the Praehedbergellidae and Schackoinidae, which never developed muricae, also never developed extended portici to partly enclose the umbilicus.

We suggest that the Praehedbergellidae and Schackoinidae lived at or near the sea surface (where the 
warmth and oxygenation of surface waters permitted survival with a low test porosity), where the finest particulate nutrients remained in suspension. With the migration of Globigerinacea to deeper waters, not only was there a necessary increase in test porosity, but it also became advantageous to gather and disaggregate the larger, heavier particulates which had sunk from the upper waters. Probably in order to achieve this, aperturally-associated muricae (and, ultimately, modified umbilici) were evolved.

With the aquisition of muricae in the Hedbergellidae and Planomalinidae, muricocarinae could develop (no keels are known in the Praehedbergellidae and Schackoinidae). It is known that the spines of living Globigerinidae are covered by extrathalamous extensions of the cytoplasm, capable not only of carrying vacuoles and transporting symbionts (Hemleben and Spindler, 1983, pl. 1, figs. 3,4 ) but also of performing the feeding and exchange functions of axopodia when the latter are lost (Adshead, 1980). The carinae of some predatory, biconvex benthic Rotaliina (e.g., Amphistegina) have been observed to form the foundation of the "take-off" of food-gathering pseudopodia (Banner, 1978). Is it not possible that the peripheral muricae, and, later the muricocarinae, of the Hedbergellidae and its descendants functioned similarly, as a peripheral rim from which food gathering pseudopodia could extend in a disc-like fan?

The smooth, nonmuricate, noncarinate, Praehedbergellidae and Schackoinidae could have had no skeletal control on the distribution of sites for pseudopodial extensions into the surrounding seawater. The pseudopodia would either have extended irregularly or would have occupied a volume approximating to that of a sphere. If the same volume is compressed into a disc, the surface area for prey capture or collection must be very greatly increased. Therefore, species which could extrude the pseudopodia into such a disc must have had considerable advantage in the collection of available suspended particulate nutrients. This could be the reason for the repeated success of taxa which evolved muricocarinae (or other keels), and for the success of the Hedbergellidae and its descendants in supplanting the Praehedbergellidae and Schackoinidae from their dominant position in the biota.

The pustules and muricae of the Favusellacea are unlikely to have been associated with the disaggregation of nutrient particulates because they are not concentrated around the umbilicus or the aperture. However, in the Globuligerinidae they may have had the function of distributing sites of pseudopodial extension more uniformly over the test surface. Even in the Favusellidae, relict muricae may still be seen at some confluences of the reticulation ridges; in such cases, their distribution is analogous to that of the distribution of spine bases in the "pore pit" reticulation of Neogene Globigerinoides (e.g. Bé, 1980, pl. 3). The reticulation on the surface of favusellids must have impeded flow of extrathalamous cytoplasm over the test surface; the function of this structure is unknown (like that of the Neogene "pore-pits"), and it has never evolved again in the Globigerinina.

\section{ACKNOWLEDGEMENTS}

We wish to thank P. F. Rawson and A. R. Lord (University College London) for their support and advice, and the former particularly for his guidance in the collection from the Speeton Cliff outcrop. We also thank W. Riegraf (Münster) for valuable discussions and $H$. P. Luterbacher (Tübingen) for his courtesy in allowing us to study D.S.D.P. and other samples in his laboratory. We are grateful to B.P. Petroleum Development Ltd. (especially to S. Duxbury) for permission to study assemblages from the Barremian Kopervik formation; these will be the subject of a later paper. A. A. H. Wonders and J. A. Crux (B.P. Research Centre) must be thanked for helpful comment and criticism. We are grateful to F. Gradstein (Atlantic Geoscience Centre, Bedford, Institute of Oceanography) for donating samples from Portugal previously studied by B. Stam. We must acknowledge with thanks the supply of samples through the assistance of the International Ocean Drilling Program (especially the Curator and Assistant Curator, D.S.DD.P./I.O.D.P., Scripps Institute of Oceanography). We are very grateful to M. J. Brolsma and M. Wannier (Shell U.K. Exploration and Production) for supplying us with samples collected frm outcrop sections in northern Tunisia. We acknowledge with gratitude the financial support received from NERC.

\section{Manuscript received June 1987 \\ Revised manuscript accepted February 1988}

\section{REFERENCES}

Abdel-Kireem, M. R., 1980. Genus Globigerinelloides from subsurface Upper Cretaceous deposits of the Prikaspian Depression, USSR. Revista Española de Micropaleontologia, 12, 179-190.

Adshead, P. C. 1980. Pseudopodial variability and behaviour of globigerinids (Foraminiferida) and other planktonic Sarcodina developing in culture. Cushman Fdn. Foram. Res., Special Publ. 19, 96-126.

Alexander, S. P. 1985. The cytology of certain benthonic foraminifera in relation to test structure and function. University of Wales, Ph.D. thesis.

Alexander, S. P. and Banner, F. T. 1984. The functional relationship between skeleton and cytoplasm in Haynesina germanica (Ehrenberg). Journal of Foram. Res., 14(3), $159-170$.

Ali-Zade, A., and Khalilov, A. G., (Eds). 1986. Skhemi stratigrafii nizhnemelovikh otlozhenii Azerbaidzhana. Akademiya Nauk Azerbaidzhanskoi SSR, Inst. Geol. im. akad. Gubkina, "Elm", Baku, 67 pp. Atlas. 
Antonova, Z. A., Saidova, L. A., Kalugina, O. M. and Shmigina, T. A., 1974. Raschlenenie nizhnemelovikh otlozhenii Severo-Zapadnogo Kavkaza po dannim izucheniya foraminifer. Sovietskaya Geologiya, 7(1974), 97-111.

Antonova, Z. A., Shmigina, T. A., Gnedina, A., and Kalugina, O. M. 1964, Neokom i Apt Mezhduretsiya Pshekha-Ubin (Severo-Zapadnii Kavkaz). Voprosi Stratigrafiyu $i$ litologii Mezozoiskikh i Kainozoiskikh otlozhenii Krasnodarskogo Kraya. Trudi Krasnodar. Fil. Vsesoyuz. Neftegaz, 12, 3-72.

Ascoli, P., 1976. Foraminiferal and ostracod biostratigraphy of the Mesozoic-Cenozoic, Scotian shelf, Atlantic Canada. Maritime Sediments, Spec. Publ. 1, 653-771.

Ayala-Castañares, A., 1962. Morfologiya y estructura de algunos foraminiferos planctonicos del Cenomaniano de Cuba. Bol. Soc. Geol. Mexicana. 25(1) 1-63.

Bandy, O. L., 1967. Cretaceous planktonic foraminiferal zonations. Micropaleontology, 13(1), 1-31.

Banner, F. T., 1978. Form and function in coiled benthic foraminifera. The British Micropalaeontologist, 8, 11-12.

Banner, F. T., 1982. A classification and introduction to the Globigerinacea in Banner, F. T., and Lord, A. R. (Eds.) Aspects of Micropaleontology, Allen and Unwin, London, 142-239.

Banner, F. T.. Pereira, C. P. G., and Desai, D., 1985. "Tretomphaloid" float chambers in the Discorbidae and Cymbaloporidae. Jour. Foraminiferal Research, 15, 159 -174 .

Banner, F. T., and Strank, A. R. E., 1987. On Wondersella athersuchi, a new stratigraphically significant Hedbergellid from the Shuaiba Formation of the Middle East. $J$. Micropalaeont. 6(1), 39-48.

Banner, F. T., and Williams, E., 1978. Test structure, organic skeleton and extra-thalamous cytoplasm of Ammonia Brunnich. Jour. Foraminiferal Research, 3, 49-69.

Barr, F. T., 1962. Upper Cretaceous planktonic foraminifera from the Isle of Wight, England. Palaeontology, 4, $552-580$.

Bars, H. and Ohm, U., 1968. Der Dogger des Profils Rocchetta, Prov. Trient, Italien. "Globigerina spuriensis" n.sp. Neues Jahrb. Geol. Pal., Monatsh., Stuttgart, 10, 577-590.

Bartenstein, H., 1965. Taxionomische revision und Nomenklator zu Franz E. Hecht "Standard-Gliederung der Nordwestdeutschen Unterkreide nach Foraminiferen" (1938) Teil 4: Alb. Senckenbergiana Lethaea, $46(4 / 6)$, $327 / 366$.

Bartenstein, H. and Bolli, H., 1986. The Foraminifera in the Lower Cretaceous of Trinidad, W. I. Part 5: Maridale Formation, Upper Part; Hedbergella rohri zone. Eclogae geol. Helv., 79(3), 945-999.

Bé, A. W. H., 1980. Gametogenic calcification in a spinose planktonic foraminifer, Globigerinoides sacculifer (Brady). Marine Micropaleontology, 5, 2283-310.

Blow, W. H., 1979. The Cainozoic Globigerinida, E. J. Brill, Leiden, 1-1413.

Bolli, H. M., 1957. The foraminiferal genera Schackoina Thalmann, emended and Leupoldina $\mathrm{n}$. gen. in the Cretaceous of Trinidad. Eclogae geol. Helv., 50, 271-278.

Bolli, H. M., 1959. Planktonic foraminifera from the Cretaceous of Trinidad, BWI. Bull. American Paleontol., 39(179) 257-277.

Bolli, H. M., 1966. Zonation of Cretaceous to Pliocene marine sediments based on planktonic foraminifera. $\mathrm{Bol}$. Informativo, Asoc. Venezolana de Geol., Min. y Petrol., 9,
3-32.

Butt, A., 1979. Lower Cretaceous foraminiferal biostratigraphy, paleoecology, and depositional environment at D.S.D.P. site 397, Leg 47A. Initial Reports of the Deep Sea Drilling Project, 47(1), 251-271, Washington (US Govt. Printing Office).

Caron, M., 1978. Cretaceous planktonic foraminifers from D.S.D.P. Leg 40, Southeastern Atlantic Ocean. Initial Reports of the Deep Sea Drilling Project, 40, 651-678. Washington (US Govt. Printing Office).

Caron, M., 1983. La spéciation chez les foraminifères planctoniques: une response adaptée aux constraints de l'environment. Zitteliana, 10, 671-676.

Caron, M., 1985. Cretaceous planktonic foraminifera. Chap. 4, in Bolli, H. M., Saunders, J. B., and Perch-Nielsen, K.. (Eds.) Plankton Stratigraphy, 17-86, Cambridge University Press.

Caron, M. and Homewood, P., 1983. Evolution of early planktic foraminifers. Marine Micropaleontology, 7, 453 -462 .

Chevalier, J., 1961. Quelques nouvelles espèces de foraminifères dans le Crétacé inférieur mediterranéen. Rev. Micropal. 4(1), 30-36.

Frerichs, W. E., and Ely, R., 1978. Test porosity as a paleoenvironmental tool in the Late Cretaceous of the Western Interior. Univ. Wyoming, Contrib. Geology, 16(2), 89-94.

Frerichs, W. E., Heiman, M. E., Borgman, L. E., and Bé, A. W. H., 1972. Latitudinal variations in planktonic foraminiferal test porosity. I. Optical Studies. Jour. Foraminiferal Research, 2, 6-13.

Fuchs, W., 1973. Ein Beitrag zur Kenntnis der Jura"Globigerinen" und verwandter Formen an Hand polnischen Materials des Callovien und Oxfordien. Verhandlungen der Geologischen Bundesanstalt., 3, 445-487.

Fuchs, W., 1975. Zur Stammergeschichte der Planktonforaminiferen und verwandten Formen in Mesozoikum. $J b$. Geol. Bundesanstalt., 118, 193-246.

Glaessner, M. F., 1966. Notes on Foraminifera of the genus Hedbergella. Ecl. geol. Helvetiae, 59, 179-184.

Gofman, E. A., 1958. Novie nakodki yurskikh globigerinick Nauch. Dokl. Vissh. Skoli, Ser. geol.-geogr. Nauk, 2, 125-126.

Gorbachik, T. N., 1964. Variability and microstructure of the wall of the test in Globigerinelloides algerianus. Paleont. Zhurnal, 4, 33-36.

Gorbachik, T. N., 1971. On Early Cretaceous foraminifera of the Crimea. Voprosi Micropaleont., 14, 125-139 (pls. 21-30, given in text as plates 1-10).

Gorbachik, T. N., 1986. Jurassic and Early Cretaceous planktonic foraminifera of the south of the USSR (in Russian). AN SSSR, "Nauka". 239 pp, 32 pls.

Gorbachik, T. N., and Krechmar, V., 1971. Structure of the wall of some Early Cretaceous planktonic foraminifera. Voprosi Micropaleont., 14, 17-24.

Gorbachik, T. N., and Kuznetsova, K. I., 1983. Jurassic and Early Cretaceous planktonic foraminifera (Favusellidea). Stratigraphy and paleobiogeography. Zitteliana, 10, 459 -466 .

Gorbachik, T. N., and Kuznetsova, K. I., 1984. Granitsa Yuri u Mela. Foraminiferi. In Menner, V. V. (Ed.) Pogranichnie yarusi Yurskoi i Melovoi Sistem. Akad. Nauk SSSR, Sibirskoe Otdelenie Inst. Geol. i Geofis., Trudi, 644, 124-137.

Gorbachik, T. N., and Kuznetsova, K. I., 1986. Izuchenie 
mineralnogo sostava rakovin planktonnikh foraminifer. Voprosi Mikropaleontologii, 28, 42-44.

Gorbachik, T. N., and Moullade, M., 1973. Caractères microstructuraux de la paroi du test des Foraminifères planctoniques du Crétacé inférieur et leur signification sur le plan taxonomique. C. R. Acad. Sc. Paris, 277 (D), 2661-2664.

Gorbachik, T. N., and Poroshina, L. A., 1979. New Berriasian planktonic foraminifera from Azerbaijan: Paleontologisheskii Zhurnal, 13(3), 22-27; English translation: Paleontological Journal, 13(3), 283-289.

Grigelis, A. A., 1985. Zonalnaya Stratigrafiya, V Baltiskoi Yuri po Foraminiferam. Ypravlenie Geologii Litovskoi SSR, Litovskii Nauchno-Issledovatelskii Geologorazvedochnii Institut. Moskva, "Nedra", $130 \mathrm{pp}$.

Grigelis, A., and Gorbachik, T., 1980. Morphology and taxonomy of Jurassic and Early Cretaceous representatives of the superfamily Globigerinacea (Favusellidea). $J$. Foram. Res., 10(3), 180-190.

Grigelis, A. A., Mesezhnikov, M. S., Yakovleva, S. P., and Kozlova, G. E., 1977. Pervie nakhodki planktonnikh foraminfer v verkhnei yure basseina r. Pechori. Dokladi Akad. Nauk SSSR (Geol.), 233, 926-927.

Hamaoui, M., 1965. On a new subgenus of Hedbergella Foraminiferida). Israel Jour. Earth Sci., 13 (1964), 133 -142 .

Hart, M. B., Bailey, H. W., Fletcher, B.. Price, R., and Sweicicki, A. 1981. Chapter 7, Cretaceous, In Jenkins, D. G., and Murray, J. W., (Eds) Stratigraphical Atlas of fossil foraminifera. Ellis Horwood Ltd. Chichester, for the British Micropalaeontological Society, 310 pp.

Hart, M. B., and Ball, K. C., 1986. Late Cretaceous anoxic events, sea-level changes and evolution of the planktonic foraminifera. In Summerhayes, C. P., and Shackleton, N. J., (Eds.) North Atlantic Palaeoceanography. Geol. Soc. Spec. Publ. No. 21, 67-78. Blackwell Scientific Publications, Oxford.

Hecht, F. E., 1938. Standard-Gliederung des Nordwestdeutschen Unterkreide nach Foraminiferen. Senckenberg Naturf. Ges. Abh., Frankfurt, 443, 3-42.

Hemleben, Ch., and Spindler, M., 1983. Recent advances in research on living planktonic foraminifera. In Meulenkamp, J. E. (Ed.), Reconstruction of marine paleoenvironments. Utrecht Micropal. Bull. 30, 141-170.

Iovčeva, P., andd Trifonova, E., 1961. Globigerina v S. Z. Bolgarii. Trudove Geol. Bolgariya, ser. Paleontol., 3 , 343-347.

Jansen, H., Krom, D., and van Hinte, J. E., 1984. Entry and exit of Planomalina buxtorfi in a section north of Velez Blanco, South-eastern Spain. Rev. Española de Micropaleont., 16, 381-397.

Kaye, P., 1964. Observations on the Speeton Clay (Lower Cretaceous). Geol. Mag., 101, 340-356.

Kuhry, B., 1971. Lower Cretaceous planktonic foraminifera from the Miravetes, Argos and Represa formations (S.E. Spain). Revista Española de Micropaleont., 3, 219-237.

Kuznetsova, K. I., and Gorbachik, T. N., 1980. Novie nakhodki planktonnikh foraminifer, $\mathrm{v}$ verkhyurskikh otlozhenii Krime. Dokladi AN SSR, 254(3), 748-751.

Kuznetsova, K. I., and Gorbachik, T. N., 1985. Stratigrafiya i foraminiferi verknnei Yuri i Nizhnevo Mela Krima. $A N$ SSSR Ordena Tryd. Kras. Znameni Geol. Inst., Trudi, 395 , $1-126$.

Kuznetsova, K. I., and Uspenskaya, E. A., 1980. Novie nakhodki planktonnikh foraminifer $v$ verkhneyurskikh otlozhenii Krima. Akademii Nauk SSSR, Dokladi, 259(3). $748-751$.

Li Qianyu, 1986. Ultrastructure, morphology, affinities and reclassification of Cassigerinella Pokorný (Foraminiferida, Globigerinina). J. Micropaleontology, 5, 49-64.

Li Qianyu, 1987. Origin, phylogenetic development and systematic taxonomy of the Tenuitella plexus (Globigerinitidae, Globigerinina). J. Foram. Res. 17, 298-320.

Loeblich, A. R. Jr., and Tappan, H., 1961. Cretaceous planktonic foraminifera: Part 1-Cenomanian. Micropalaeontology. 7(3), 257-304.

Loeblich, A. R. Jr., and Tappan, H., 1964. Treatise on Invertebrate Paleontology Part C, Protista 2, Sarcodina, chiefly "Thecamoebians" and Foraminiferida. Geol. Soc. Amer., Univ. Kansas Press., 2, C511-C900.

Loeblich, A. R. Jr., and Tappan, H., 1984. Suprageneric classification of the Foraminiferida (Protozoa). Micropalaeontology, 30, 1-70 (especially 37-39).

Longoria, J. F., 1974. Stratigraphic, morphologic and taxonomic studies of Aptian planktonic foraminifera. Revista Española de Micropaleontologia, Numero Extraordinario, 5-107.

Longoria, J. F., and Gamper, M. A., 1977. Albian planktonic foraminifera from the Sabinas Basin of northern Mexico. $J$. Foram. Res., 7(3), 196-215.

Magniez-Jannin, F., 1981. Decouverte de Planomalina buxtorfi (Gandolfi) et d'autres foraminifères planctoniques inattendus dans l'Albien supérieur d'Abbotscliff (Kent, Angleterre); consequences paléogéographiques et biostratigraphiques. Geobios, 14(1), 91-97.

Magniez, F., and Sigal, J., 1984. Barremian and Albian foraminifera, Site 549, Leg 80. Chapter 18 in Graciansky, P. C. de, Poag, C. W., et al., Initial Reports Deep Sea Drilling Project 80, Washington (US Govt. Printing Office), $601-628$.

Marianos, A. W., and Zingula, R. P., 1966. Cretaceous planktonic foraminifers from Dry Creek, Tehama County, California. Jour. Paleont. 40(2), 328-342.

Masella, L., 1960. Le Schackoina (Foraminifera, Globigerinacea) del Cretaceo di Patti (Messina). Rivista Mineraria Siciliana, 11(61), 3-17.

Masters, B. A., 1977. Mesozoic Planktonic Foraminifera. In Ramsay, A. T. S. (Ed.), Oceanic Micropalaeontology, I, 301-731. Academic Press, N. Y.

Michael, F. Y., 1973 (1972), Planktonic foraminifera from the Comanchean Series (Cretaceous) of Texas. J. Foram. Res., 2(4), 200-220.

Morozova, V. G., 1948. Foraminiferi nizhnemelovikh otlozhenii rayona g. sochi (Yugozapadnoi Kavkaz). Moscov. Obshch. Ispyt. Prirodi, Otdel Geol., Byull., 23(3), $23-43$.

Morozova, V. G., and Moskalenko, T. A., 1961. Planktoniie foraminiferi progranichnikh otlozhenii bayosskogo $i$ batskogo yaruso-tsentralnogo Dagestan (severo-vostochnii Kavkaz). Voprosi Mickropaleontologii, 5, 3-30.

Moullade, M., 1966. Étude stratigraphique et micropaléontologique du Crétacé inférieur de la "Fosse Vocontienne". Doc. Laboratoires de la Faculté des Sciences de Lyon, no. 15 , fasc. $1-2,369 \mathrm{pp}, 17$ pls.

Mutterlose, J., 1984. Die Unterkreide-Aufschlusse (Valangin-Alb) im Raum Hannover-Braunschweig. Mitt. geol. Inst. Univ. Hannover, 24, 1-61.

Obata, I., Maiya, S., Inoue, Y., and Matsukawa, M., 1982. Integrated mega- and micro-fossil biostratigraphy of the Lower Cretaceous Choshi Group, Japan. Bull. Natn. Sci. 
Mus, Tokyo, Ser. C,8(4), 147-172.

Obregón de la Parra, J., 1959. Foraminiferos de la formación la Peña. Assoc. Mex. Geol. Petr., Bol., 11(314), 135-153.

Pazdrowa, O., 1969. Bathonian Globigerina of Poland. Polsk. Tow. Geol. Rocznik (Soc. Geol. Pologne, Ann.), Krakow, 39 (1-3), 42-54.

Pessagno, E. A., Jr., 1969. Upper Cretaceous stratigraphy of the Western Gulf Coast of Mexico, Texas, and Arkansas. Geological Society of America, Memoir 111, 1-139.

Plummer, H. J., 1931. Some Cretaceous foraminifera in Texas. Texas Univ. (Bur. Econ. Geol.), Bull. 3101, 109-203.

Porthault, B. (in Donze, P., Porthault, B., Thomel, G., and de Villoutreys, O.), 1970. Le Senonien inférieur de Puget-Théniers (Alpes-Maritimes) et sa microfaune. Geobios, 3(2), 41-106.

Rawson, P. F., Curry, D., Dilley, F. C., Hancock, J. M., Kennedy, W. J., Neale, J. W., Wood, C. J., and Worssam, B. C., 1978. A correlation of Cretaceous rocks in the British Isles. Geol. Soc. London, Special Report No. 9, 70 pp.

Reichel, M., 1948. Les Hantkéninidés de la Scaglia et des Couches rouges (Crétacé supérieur). Eclogae geol. helv'., 40 (1947), no. 2, 391-409.

Riegraf, W., 1987a. Planktonic foraminifera (Globuligerinidae) from the Callovian (middle Jurassic) of southern Germany. Journal of Foraminiferal Research 17(3), 190 $-211$.

Riegraf, W., 1987b. Planktonic foraminifers from Callovian to Oxfordian (Jurassic) deposits of southern Germany. $N . J b$. Geol. Paläont., 176, 91-103.

Robaszynski, F., and Caron, M., 1979. Atlas of mid Cretaceous planktonic foraminifera (Boreal Sea and Tethys). Cahiers de Micropaléontologie, ed. CNRS, Paris: I, 185 pp: 2, 181 pp.

Robaszynski, F., Caron, M., Gonzalez Donoso, J. M., and Wonders, A. A. H., 1984. Atlas of Late Cretaceous Globotruncanids. Revue de Micropaléontologie, 26, 145 -305 .

Rösler, W., Lutze, G. F., and Pflaumann, U., 1979. Some Cretaceous planktonic foraminifers (Favusella) of DSDP Site 397 (Eastern North Atlantic). Initial Reports of the Deep Sea Drilling Project, 47(1), 273-277. Washington (U.S. Govt. Printing Office).

Ruggieri, G., 1963. Globigerinelloides algeriana nell'Aptiano della Sicilia. Soc. Pal. Ital., Bull. 2(2), 77-78.

Salaj, J., 1984. Foraminifers and detailed microbiostratigraphy of the boundary beds of the Lower Cretaceous stages in the Tunisian Atlas Geol. Carpathica, 35(5), 583-599.

Sigal, J., 1952. Aperçu stratigraphique sur la micropaléontologie du Crétacé. 19 - Congr. Géologique Internat., Monogr. Regionales(1) Algérie (26), Algiers, 47 pp.

Sigal, J., 1959. Notes micropaléontologiques alpines. Les genres Schackoina et Leupoldina dans le Gargasien Vocontien. Étude de morphogénèse. Revue de Micropaléontologie, 2, 68-79.

Sigal, J., 1965. Etat des connaissances sur les foraminifères du Crétacé Inférieur. Colloque sur le Crétacé Inférieur (Lyon, Septembre 1963), Mem. du Bureau de Recherches Géologiques et Minières, 34, 489-502.

Sigal, J., 1966a. Contribution à une monographie des Rosalines. 1. Le genre Ticinella Reichel, souche des Rotalipores. Ecologae geol. Helvetiae, 59(1), 186-217.

Sigal, J., 1966b. Le concept taxinomique du spectre. Exemples d'application chez les foraminifères. Propositions de règles de nomenclature. Soc. géol. France, Mém., HorsSerie 3, 1-126.

Sigal, J., 1977. Essai de zonation du Crétacé mediterranéenne, 4, 99-108.

Sigal, J., 1979. Chronostratigraphy and ecostratigraphy of Cretaceous formations recovered on DSDP Leg 47B. Site 398. Initial Reports of the Deep Sea Drilling Project, 47(2), 287-326. Washington, (U.S. Govt. Printing Office).

Smith, C. C., and Pessagno, E. A., 1973. Planktonic foraminifera and stratigraphy of the Corsicana formation (Maastrichtian), north-central Texas. Cushman Fdn. Foram. Res., Spec. Publ. 12, 1-68.

Spindler, M., Hemleben, Ch., Solomons, J. B., and Smit, L. P., 1984. Feeding behaviour of some planktonic foraminifers in Laboratory cultures. Jour. Foraminiferal Res., 14, $237-249$.

Stam, B.. 1986. Quantitative analysis of Middle and Late Jurassic foraminifera from Portugal and its implications for the Grand Banks of Newfoundland. Utrecht Micropaleontological Bulletins, 34, 1-168.

Subbotina, N. N., 1949. Microfauna of the Cretaceous of the southern slope of the Caucasus. (in Russ.), VNIGRI, Microfauna of the oilfields of the USSR, Sb.2, Trudi, n.s., $34,5-36$.

Subbotina, N. N., 1953. Globigerinidi, Hantkeninidi i Globorotaliidi: Iskopaemie Foraminiferi SSSR. Trudi, VNIG$R I, 76,1-296$.

Swift, J., 1726. Travels into several remote nations of the world, Part 1, Chapter 4. Benjamin Motte, London.

Tappan, H., 1940. Foraminifera from the Grayson formation of northern Texas. Jour. Paleont., 14, 93-126.

Tronchetti, G., 1981. Les foraminifères Crétacé de Provence (Aptien-Santonien). Thèse, l'Université de Provence, UER de Sciences Naturelles RCP no. 510; Trav. du Lab. de Géol. Historique et de Paléontologie, no. 12, 1981; 196 pp, 49 pls.

Wernli, R., and Kindler, P., 1986. Les "protoglobigerines" du Callovien-Oxfordien de Chatillon-sur-Cluses (Préalpes internes, Haute Savoie, France). Ecologae geol. Helvetiae, $79(1), 137-147$.

Wind, F. H., and Cepek, P., 1979. Lower Cretaceous calcareous nanno-plankton from DSDP hole 397A (northwest African margin). Initial Reports of the Deep Sea Drilling Project, 47(1), 221-255. Washington, D.C. (U.S. Govt. Printing Office)

Wonders, A. A. H., 1975. Cretaceous planktonic foraminifera of the Planomalina buxtorfi group from El Burrueco, southern Spain. Proc. Kon. Ned. Akad. Wet., Ser. B. $78,83-93$.

Wonders, A. A. H., 1980. Middle and Late Cretaceous planktonic foraminifera of the Western Mediterranean area. Utrecht Micropalaeontological Bulletins, 24, $157 \mathrm{pp}$.

Zakharova-Atabekyan, L. V., 1961. Krevisii sistematiki Globotruncanid i predlozhenii novogo roda Planogyrina nov. gen. Dokl. Akad. Nauk Armyanskoi SSR, 32(1) $49-53$. 